UNITED STATES DEPARTMENT OF THE INTERIOR

GEOLOGICAL SURVEY

\author{
Bibliography for Map of \\ Prospective Hydrocarbon Provinces of the World
}

By Anny B. Coury,

Thomas A. Hendricks, and Theodore F. Tyler

Open-File Report 79-201

1979

This report is preliminary and has not been edited or reviewed for conformity with U.S. Geological Survey standards and nomenclature. 


\section{Contents}

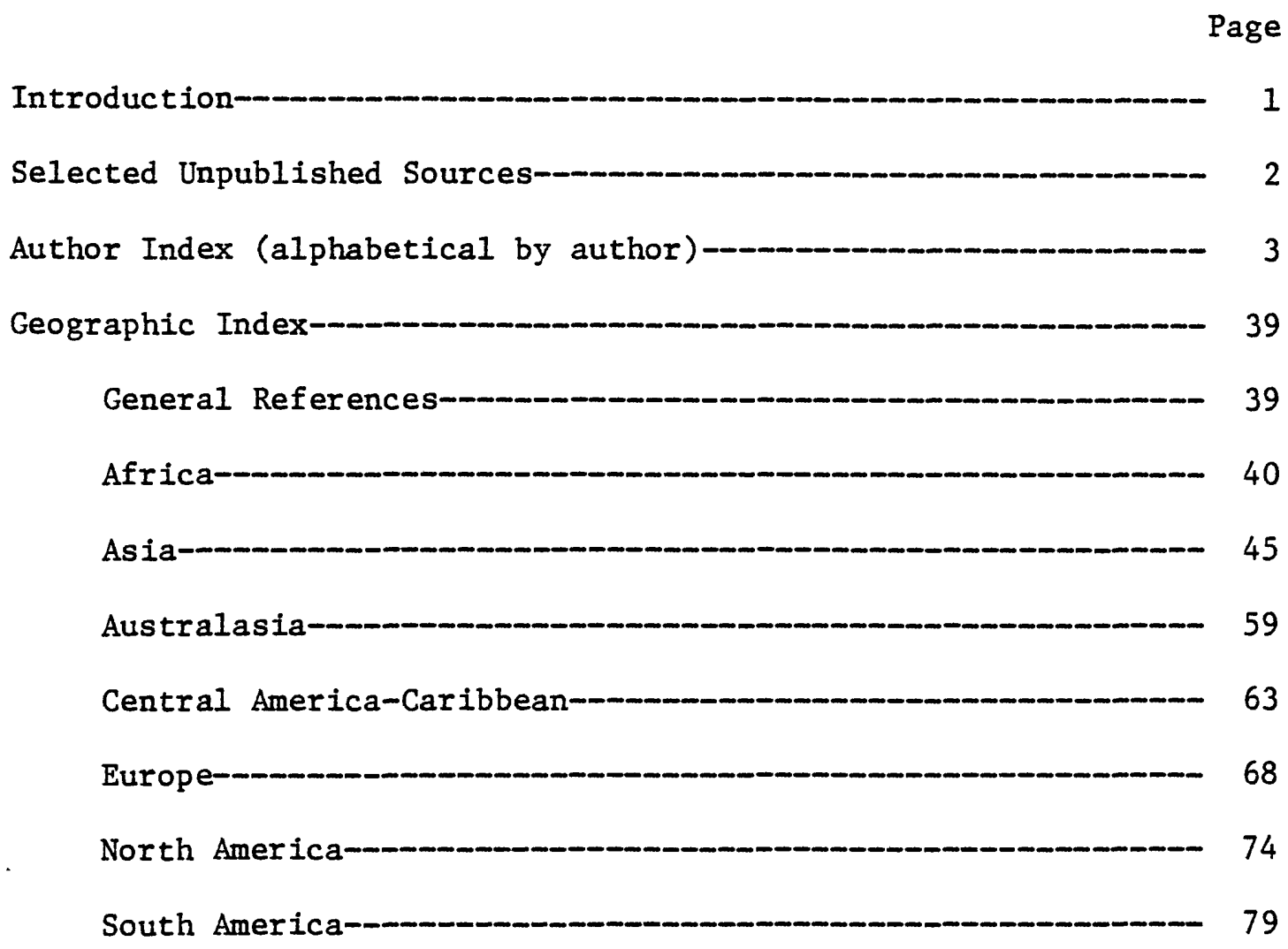




\title{
BIBLIOGRAPHY FOR MAP OF \\ PROSPECTIVE HYDROCARBON PROVINCES OF THE WORLD
}

\author{
INTRODUCTION
}

This bibliography includes the references that were used in the preparation of the "Map of Prospective Hydrocarbon Provinces of the World." The map is published in three sheets as Map MF 1044 A, North and South America by A. B. Coury, T. A. Hendricks, and T. F. Tyler; Map MF 1044B, Europe, West Asia, and Africa by A. B. Coury and T. A. Hendricks; and Map MF 1044C, East Asia, Australia, and the Pacific by A. B. Coury and T. A. Hendricks.

An interrupted Sinusoidal equal area projection was used for the maps to facilitate areal comparisons; the scale is $1: 20,000,000$. The maps depict areas, both onshore and offshore, that either contain known oil or natural gas deposits or are favorable for their occurrence. These areas consist mostly of basins containing unmetamorphosed sedimentary rocks of greater than $1000 \mathrm{~m}$ thickness. Also included are some platforms and uplifts, foldbelts, and thinner rock sequences.

The bibliography consists of three sections: (1) selected unpublished sources, (2) author index, and (3) geographic index. The selected unpublished sources and the author index are arranged alphabetically according to the senior author's last name. The geographic index is arranged by continents or subcontinents, followed by minor geographic units, i.e. countries, regions and bodies of water. The references are arranged alphabetically by author within each geographic unit. When a reference covers several geographic areas, it is appropriately crossreferenced in the geographic index. Publications of foreign ministries or bureaus are listed under the respective country, with that country's name spelled in English style. 
Case, J. E., 1975, Basin and province map, Caribbean area: Unpublished work map, scale 1:5,000,000.

Kintanar, E. R. L., 1966, Petroleum geology of the Philippines: Paper presented to 2nd Geol. Convention and 1st Symposium on the Geology of the Mineral Resources of the Philippines and Neighboring Countries (October 1966).

Martin, R. G., Jr., 1975, Isopach of sediments on Paleozoic and oceanic basement--Gulf Coast, USA: Unpublished work map, scale 1:5,000,000.

Mattick, R. E., Foote, R. Q., Weaver, N. L., and Grim, M. S., 1974, A preliminary report on USGS geophysical studies on the northeastern US outer continental shelf: Paper presented to annual meeting of Northeastern Section of Geological Society of America, Baltimore (March 1974).

Merrill, W. R., and McNaughton, D. A., 1962, Geology and exploration in the Philippines: Paper presented to National Convention of the American Association of Petroleum Geologists, San Francisco (March 1962).

Pulunggono, A., 1974, Recent knowledge on hydrocarbon potentials in the sedimentary basins of Indonesia: Handout of paper presented at Circum-Pacific Energy and Mineral Resources Conferences, 26 p.

Robertson Research International Ltd., 1975, New Zealand, Petroleum prospects of the onshore Taranaki Basin: Robertson Research International Ltd., p. 2 of informal memo.

Terman, M. J., 1975, Work maps of sedimentary basins of Asia and the USSR: Unpublished work maps, scale 1:5,000,000. 


\section{AUTHOR INDEX}

Acosta-Estevez, R., 1973, Petroleum development in Mexico in 1972: American Association of Petroleum Geologists Bulletin, v. 57, no. 10, p. 2126-2135.

Adeleye, D. R., 1975, Nigerian late Cretaceous stratigraphy and paleogeography: American Association of Petroleum Geologists Bulletin, v. 59, no. 12, p. 2302-2313.

Ahmed, S. S., 1969, Tertiary geology of part of south Makran, Baluchistan, West Pakistan: American Association of Petroleum Geologists Bulletin, v. 53, no. 7 , p. 1480-1499.

Allen, R. J., 1974, Hydrocarbon significance of upper Palaeozoic sediments associated with the Koburra Trough, Galilee Basin: Australian Petroleum Exploration Association Journal, v. 14, pt. 1, p. 59-65.

Almy, C. C., Jr., 1969, Sedimentation and tectonism in the upper Cretaceous Puerto Rican portion of the Caribbean Island arc: Gulf Coast Association of Geological Soieties Transactions, v. 19, p. 269-279.

Alvarez, M., Jr., 1949, Tectonics of Mexico: American Association of Petroleum Geologists Bulletin, v. 33, no. 8, p. 1319-1335.

Amoco Canadian Petroleum Company Ltd. and Imperial 0il Ltd., offshore exploration staffs, 1974, Regional geology of the Grand Banks: American Association of Petroleum Geologists Bulletin, v. 58, no. 6, pt. 2, p. 1109-1123.

Arens, G., and others, 1971, The continental margin off the Ivory Coast and Ghana, in Delany, F. M., ed., The geology of the east Atlantic continental margin--4 Africa: Great Britain Institute of Geological Sciences Report 70/16, p. 61-78.

Asmus, H. E., and Ponte, F. C., 1973, The Brazilian marginal basins, in Nairn, A. E. M., and Stehli, F. G., eds., The ocean basins and margins, Volume 1, The South Atlantic: New York, Plenum Press, p. $87-132$.

Auldridge, L., 1975, Pakistan oil search gaining momentum: $0 i 1$ and Gas Journal, v. 73 , no. 18, p. 152-153.

Austin, P. M., Sprigg, R. C., and Braithwaite, J. C., 1973, Structure and petroleum potential of Eastern Chatham Rise, New Zealand: American Association of Petroleum Geologists Bulletin, v. 57, no. 3, p. 477-497.

Australia Bureau of Mineral Resources, 1952, Geological map of Australia and New Guinea: Australia, Bureau of Mineral Resources, Geology and Geophysics, scale 1:6,336,000. 
1965, Geological map of the world, Australia and Oceania: Australia, Bureau of Mineral Resources, Geology and Geophysics, scale $1: 5,000,000$.

Australia, Geological Society of, 1971, Tectonic map of Australia and New Guinea: Geological Society of Australia, scale 1:5,000,000.

Auzende, J. M., and 01ivet, J. L., 1974, Structure of the western Mediterranean Basin, in Burk, C. A., and Drake, C. L., eds., The geology of continental margins: New York, Springer-Verlag, p. 723731.

Avbovbo, A. A., 1978a, Tertiary 1ithostratigraphy of Niger Delta: American Association of Petroleum Geologists Bulletin, v. 62, no. 2, p. 295-306.

1978b, Geothermal gradients in the southern Nigeria Basin: Bulletin of Canadian Petroleum Geology, v. 26, no. 2, p. 268-274.

Avrov, V. Y., and others, 1967, Map of prospective oil and gas regions of the USSR: Moscow, Ministry Geology of USSR, Ministry Oil Industry of USSR, and Ministry Gas Industry of USSR, scale 1:5,000,000, 4 sheets.

Aymé, J. M., 1965, The Senegal salt basin, in Salt basins around Africa: London, Institute of Petroleum, p. 83- $\overline{90}$.

Bakirov, A. A., and Ryabukhin, G. E., eds., 1969, 0il and gas provinces and districts of the USSR: Moscow, Nedra, 478 p.

Bakirov, A. A., Varentsov, M. I., and Bakirov, E. A., 1971, 011 and gas provinces and districts of the countries of the world: Moscow, Nedra, 542 p.

Bakke, D. R., 1976, Russia begins to tap its biggest reserves off Siberia: Offshore, v. 36 , no. 4 , p. 63-67.

Ballen, J. G., 1969, Mapa geologico de la Republica del Ecuador: Servicio Nacional de Geologia y Mineria, scale $1: 1,000,000,2$ sheets.

Barr, K. W., Waite, S. T., and Wilson, C. C., 1958, The mode of oil occurrence in the Miocene of southern Trinidad, BWI, in Weeks, L. G., ed., Habitat of oil, a symposium: American Association of Petroleum Geologists, p. 533-550.

Bassinger, B. G., Harbison, R. N., and Weeks, L. A., 1971, Marine geophysical study northeast of Trinidad-Tobago: American Association of Petroleum Geologists Bulletin, v. 55, no. 10, p. 1730-1740.

Bauer, E. J., 1967, Genesis of lower Cretaceous "A" sandstone, Reconcavo Basin, Brazil: American Association of Petroleum Geologists Bulletin, v. 51 , no. 1 , p. 28-54. 
Beal, C. H., 1948, Reconnaissance of the geology and oil possibilities of Baja California, Mexico: Geological Society of America Memoir 31, $171 \mathrm{p}$.

Beck, R. H., and Lehner, P., 1974, Oceans, new frontier in exploration: American Association of Petroleum Geologists Bulletin, v. 58, no. 3, p. 376-395.

Beddoes, L. R., Jr., ed., 1973, $0 i 1$ and gas fields of Australia, Papua New Guinea and New Zealand: Australia, Tracer Petroleum and Mining Publications Pty. Ltd., 382 p.

Beebe, B. W., 1968, Occurrence of natural gas in Mexico, in Beebe, B. W., and Curtis, B. F., eds., Natural gases of North America: American Association of Petroleum Geologists Memoir 9, v. 1, p. 209-229.

Beltrandi, M. D., and Pyre, A., 1973, Geological evolution of southwest Somalia, in Blant, G., ed., Bassins sédimentaires du littoral Africain, part 2, Littoral austral et oriental (Montreal, 1972): Paris, Union Internationale des Sciences Geologiques, Association des Services Géologiques Africains, p. 159-178.

Ben-Avraham, Z., 1973, Sonobuoy refraction measurements in the Java Sea: United Nations Economic Commission for Asia and Far East, Committee for Coordination of Joint Prospecting for Mineral Resources in Asian Offshore Areas, Technical Bulletin 7, p. 39-53.

Ben-Avraham, Z., and Emery, K. O., 1973, Structural framework of Sunda Shelf: American Association of Petroleum Geologists Bulletin, v. 57 , no. 12 , p. 2323-2366.

Bertagne, R. G., 1963, Some aspects of the tectonics of the Maracaibo block, Venezuela: Asociación Venezolana de Geologla, Minerla y Petroleo Boletin Informativo, v. 6, no. 8, p. 233-260.

Bhandari, L. L., Fuloria, R. C., and Sastri, V. V., 1973, Stratigraphy of Assam Valley, India: American Association of Petroleum Geologists Bulletin, v. 57, no. 4, p. 642-654.

Bigarella, J. J., 1973, Geology of the Amazon and Parnaiba Basins, in Nairn, A. E. M., and Stehli, F. G., eds., The ocean basins and margins, Volume 1, The South Atlantic: New York, Plenum Press, p. 25-79.

Biju-Duval, B., 1974, Geological and structural map of Tertiary basins in the Mediterranean domain: Revue de I'Institut Francais du Petrole, v. 29, no. 5, p. 607-639.

Biju-Duval, B., and others, 1974, Geology of the Mediterranean Sea basins, in Burk, C. A., and Drake, C. L., eds., The geology of continental margins: New York, Springer-Verlag, p. 695-721. 
Birkelund, T., and others, 1974, An outline of the geology of the Atlantic coast of Greenland, in Nairn, A. E. M., and Stehli, F. G., eds., The ocean basins and margins, Volume 2, The North Atlantic: New York, Plenum Press, p. 125-159.

Blake, J. K., 1974, South China Sea survey holds good promise of oil and gas: Petroleum International, v. 14, no. 7, p. 31-32.

Blunde11, D. J., 1975, The geology of the Celtic Sea and Southwestern Approaches, in Yorath, C. J., Parker, E. R., and Glass, D. J., eds., Canada's continental margins and offshore petroleum exploration: Canadian Society of Petroleum Geologists Memoir 4, p. 341-362.

Bondarev, V. I., and others, 1973, Geologic structure of Novaya Zemlya, Vaygach, Pay-Khoy, Polar Urals, and northern Pechora, in Pitcher, M. G., ed., Arctic geology: American Association of Petroleum Geologists Memoir 19, p. 301-316.

Borger, H. D., and Lenert, E. F., 1959, The geology and development of the Bolivian coastal field at Maracaibo, Venezuela: World Petroleum Congress, 5th, New York, 1959, Proceedings, sec. 1, p. 481-498.

Bowin, C. 0., 1966, Geology of central Dominican Republic, in Hess, H. H., ed., Caribbean geological investigations: Geological Society of America Memoir 98, p. 11-84.

Brazil, Ministerio das Minas e Energia, 1971, Mapa geologico do Brasil: Ministerio das Minas e Energia, scale 1:5,000,000, 1 sheet.

Briggs, R. P., 1964, Provisional geologic map of Puerto Rico and adjacent islands: U.S. Geological Survey Miscellaneous Geologic Investigations Map I-392, scale $1: 240,000$.

Brown, H. D., Cunningham, J. D., and Salisch, H. A., 1970, South Lake Maracaibo $10 g$ analysis: Asociación Venezolana de Geologia, Mineria y Petroleo Boletín Informativo, v. 13, no. 11, p. 343-356.

Brown, J. C., and Dey, A. K., 1975, The mineral and nuclear fuels of the Indian Subcontinent and Burma: Delhi, Oxford University Press, p. 237-411.

Bryant, R. G., Hill, J. V., and Roliff, W. A., 1975, Development in eastern Canada in 1974: American Association of Petroleum Geologists Bulletin, v. 59, no. 8, p. 1331-1343.

Bucher, W. H., compiler, 1950, Geologic-tectonic map of the United States of Venezuela (except the Territory of Amazonas and part of the State of Bolivar): Geological Society of America, scale 1:1,000,000, 1 sheet.

1952, Geologic structures and orogenic history of Venezuela: Geological Society of America Memoir 49, 113 p. 
Burk, C. A., 1975, Sea of Okhotsk--thirteenth cruise of the Dmitry Mendeleev: Geology, v. 3, no. 3, p. 141-144.

Burlin, Y. K., and others, 1975, Sedimentary basins of the Far East and the northeast of the USSR and their possible oil and gas content: World Petroleum Congress, 9th, Tokyo, 1975, Proceedings, v. 3, p. 39-50.

Burlin, Y. K., Dontsov, V. V., and Pastukhova, T. N., 1975, Further direction of oil exploration in northeastern USSR: Petroleum Geology, v. 12, no. 5, p. 222-223.

Burma Ministry of Mine Geology Department, 1968, Geological map of Burma: Burma Ministry of Mine Geology Department, scale 1:1,000,000.

Butler, L. W., 1970, Shallow structure of the continental margin, southern Brazil and Uruguay: Geological Society of America Bulletin, v. 81, no. 4, p. 1079-1096.

Butterlin, J., 1956, La constitution géologique et la structure des Antilles: Centre National de la Recherche Scientifique, 453 p.

Byramjee, R. S., Mugniot, J. F., and Duval, B. B., 1975, Petroleum potential of deep-water areas of the Mediterranean and Caribbean Seas: World Petroleum Congress, 9th, Tokyo, 1975, Proceedings, v. 2, p. 299-312.

Caldwell, R. D., 1975, Petroleum developments in Far East in 1974: American Association of Petroleum Geologists Bulletin, v. 59, no. 10, p. 1977-2010.

Cameron, J. C., 1967, Australia's oil and gas potential--a review of the main sedimentary basins: World Petroleum Congress, 7th, Mexico City, 1967, Proceedings, v. 2, p. 152-160.

Campbe11, A. S., ed., 1971, Geology and history of Turkey: Petroleum Exploration Society of Libya, 13th Annual Field Conference, 511 p.

Campbell, C. J., and Burgl, H., 1965, Section through the eastern Cordillera of Colombia, South America: Geological Society of America Bulletin, v. 76, no. 5, p. 567-590.

Campos, C. W. M., Ponte, F. C., and Miura, K., 1974, Geology of the Brazilian continental margin, in Burk, C. A., and Drake, C. L., eds., The geology of continental margins: New York, SpringerVerlag, p. 447-461.

Canada, Geological Survey of, 1970, Geology and economic minerals of Canada, Economic Geology report no. 1: Geological Survey of Canada, 838 p.

Carlos, M. K., 1974, Geology of a part of the Pacific margin of Chile, in Burk, C. A., and Drake, C. L., eds., The geology of continental margins: New York, Springer-Verlag, p. 591-598. 
Case, J. E., and MacDonald, W. R., 1973, Regional gravity anomalies and crustal structure in northern Colombia: Geological Society of America Bulletin, v. 84, no. 9, p. 2905-2916.

Case, J. E., and others, 1971, Tectonic investigations in western Colombia and eastern Panama: Geological Society of America Bulletin, v. 82, no. 10 , p. 2685-2711.

Cecioni, G. 0., and Garcia, A. F., 1960, Stratigraphy of coastal range in Tarapaca Province, Chile: American Association of Petroleum Geologists Bulletin, v. 44, no. 10, p. 1609-1620.

Chang, S. S. L., 1968, Regional stratigraphic study of neogene formations in Chiayi-Hsinying area, west-central Taiwan, China: American Association of Petroleum Geologists Bulletin, v. 52, no. 12, p. 2438-2465.

Chapelle, J., and Ketchian, S., 1963, URSS--Second Producteur de Pétrole du Monde: Publications de L'Institut Français du Pétrole, Collection Science et Technique du Pétrole No. 4, Paris, Editions Technip, $314 \mathrm{p}$.

Chaves, R., and others, collaborators, 1968, Mapa geologico de Costa Rica: Direccion de Geologia, Minas y Petroleo, scale $1: 700,000,1$ sheet.

Childs, 0. E., and Beebe, B. W., eds., 1963, Backbone of the Americas: American Association of Petroleum Geologists Memoir 2, 320 p.

Chile Instituto de Investigaciones Geologicos, 1968, Mapa geologico de Chile: Instituto de Investigaciones Geologicos, scale 1:1,000,000, 7 sheets.

Choubert, B., principal collaborateur, 1960, Carte geologique du Department de la Guyane: Service de la Carte Géologique de la France, scale $1: 500,000,2$ sheets.

Choubert, G., general coordinator, 1968a, Carte tectonique internationale de 1'Afrique: Association of African Geological Surveys and United Nations Educational, Scientific, Cultural Organization, scale $1: 5,000,000$, 9 sheets. general coordinator, 1968b, International tectonic map of Africa, explanatory note: Association of African Geological Surveys and United Nations Educational, Scientific, Cultural Organization, 54 p.

Chowdhary, L. R., 1975, Reversal of basement-block motions in Cambay Basin, India, and its importance in petroleum exploration: American Association of Petroleum Geologists Bulletin, v. 59, no. 1, p. 8596. 
Christian, H. E., 1969, Some observations on the initiation of salt structures of the southern British North Sea, in Hepple, P., ed., The exploration for petroleum in Europe and North Africa: London, Institute of Petroleum, p. 231-250.

Christman, R. A., 1953, Geology of St. Bartholomew, St. Martin and Anguilla, Lesser Antilles: Geological Society of America Bulletin, v. 64 , no. 1 , p. 65-96.

Christofferson, E., 1973, Linear magnetic anomalies in the Colombia Basin, central Caribbean Sea: Geological Society of America Bulletin, v. 84 , no. 10 , p. 3217-3230.

Churkin, M., Jr., 1970, Fold belts of Alaska and Siberia and drift between North America and Asia, in Geological Seminar on the North Slope of Alaska, California, 1970, Proceedings: Los Angeles, American Association of Petroleum Geologists, Pacific Section, p. G1-G17.

1973, Geologic concepts of Arctic Ocean Basin, in Pitcher, M. G., ed., Arctic geology: American Association of Petroleum Geologists Memoir 19, p. 485-499.

Closs, H., Narain, H., and Garde, S. C., 1974, Continental margins of India, in Burk, C. A., and Drake, C. L., eds., The geology of continental margins: New York, Springer-Verlag, p. 629-639.

Coffinières, B., and others, 1971, Synthèse paléogeographique et pétrolière du Venezuela occidental (2 partie): Revue de l'Institut Français du Pétrole, v. 26, no. 1 , p. 50-72.

Collins, R. J., 1974, Petroleum resources and economics of Alaskan Arctic: Colorado School of Mines M.S. thesis.

Colter, V. S., and Barr, K. W., 1975, Recent developments in the geology of the Irish Sea and Cheshire Basins, in Woodland, A. W., ed., Petroleum and the continental shelf of northwest Europe, Volume 1: New York, John Wiley and Sons, p. 61-75.

Conant, L. C., and Goudarzi, G. H., 1967, Stratigraphic and tectonic framework of Libya: American Association of Petroleum Geologists Bulletin, v. 51, no. 5, p. 719-730.

Congrés Géologique International, 1962, Carte tectonique internationale de I'Europe: Congrés Geologique International, Commission de la carte géologique du monde, Sous-commission de la carte tectonique du monde, scale $1: 2,500,000,16$ sheets.

Corby, G. W., and others, 1951, Geology and oil possibilites of the Philippines: Manila, Department of Agriculture and Natural Resources, $363 \mathrm{p}$. 
Coronel, G. R., 1967, A geological outline of the Gulf of Venezuela: World Petroleum Congress, 7th, Mexico City, 1967, Proceedings, v. 2, p. 799-812.

Cram, I. H., ed., 1971, Future petroleum provinces of the United States-their geology and potential: American Association of Petroleum Geologists Memoir 15, 2 volumes, 1496 p.

Criado, R. P., and others, 1959, The sedimentary basins of Argentina: World Petroleum Congress, 5th, New York, 1959, Proceedings, sec. 1, p. 883-899.

Cserna, Z. de, 1961, Tectonic map of Mexico: Geological Society of America, scale $1: 2,500,000$.

Curray, J. R., and Moore, D. G., 1971, Growth of the Bengal deep-sea fan and denudation in the Himalayas: Geological Society of America Bulletin, v. 82, no. 3, p. 563-572.

1974, Sedimentary and tectonic processes in the Bengal deep-sea fan and geosyncline, in Burk, C. A., and Drake, C. L., eds., The geology of continental margins: New York, Springer-Verlag, p. 617628.

Dalziel, I. W. D., and others, 1974, South extremity of Andes--Geology of Isla de los Éstados, Argentina Tierra del Fuego: American Association of Petroleum Geologists Bulletin, v. 58, no. 12, p. 2502-2512.

Dalziel, I. W. D., and Elliot, D. H., 1973, The Scotia Arc and Antarctic margin, in Nairn, A. E. M., and Stehli, F. G., eds., The ocean basins and margins, Volume 1, The South Atlantic: New York, Plenum Press, p. 171-246.

Davalos, J. C., 1973, A new economy for Ecuador, in Petrick, A., Jr., ed., Texaco and Gulf strike oil: Colorado School of Mines Quarterly, v. 68 , no. 4 , p. 73-79.

Delaney, P. J. V., 1963, Quaternary geologic history of the coastal plain of Rio Grande do Sul, Brazil: Coastal Studies Institute, Technical Report No. 6, Louisiana State University, 63 p.

1966, Geology and geomorphology of the coastal plain of Rio Grande do Sul, Brazil, and northern Uruguay: Coastal Studies Institute, Louisiana State University Technical Report No. 15, 58 p.

Delteil, J. R., and others, 1974, Continental margins in the northern part of the Gulf of Guinea, in Burk, C. A., and Drake, C. L., eds., The geology of continental margins: New York, Springer-Verlag, p. 297-311. 
1978, Continental margins of the south-western Indian Ocean:

Offshore Technology Conference, 10th Annual, Houston, Texas, 1978, Proceedings, OTC 3264, p. 1835-1841.

Dengo, G., 1953, Geology of the Caracas region, Venezuela: Geological Society of America Bulletin, v. 64, no. 1, p. 7-40.

Dengo, G., and Bohnenberger, Q., 1969, Structural development of northern Central America, in Logan, B. W., and others, eds., Carbonate sediments and reefs, Yucatan Shelf, Mexico; Tectonic relations of northern Central America and the western Caribbean; and other papers on Florida and British Honduras: American Association of Petroleum Geologists Memoir 11, p. 203-220.

Denham, L. R., 1974, Offshore geology of northern west Greenland (69 to $\left.75^{\circ} \mathrm{N}\right)$ : Greenland Geological Survey Report, no. 63, 24 p.

DeSpengler, A., and Delteil, J.-R., 1966, Le bassin secondaire-tertiaire de Cote d'Ivoire, in Reyre, D., ed., Bassins sédimentaires du littoral Africain, Part 1, Littoral Atlantique (New Delhi, 1964): Paris, Union Internationale des Sciences Geologiques, Association des Services Geologiques Africains, p. 99-113.

Dillon, W. P., 1974, Structural development of the southern Moroccan continental shelf: Marine Geology, v. 16, no. 3, p. 121-143.

Dillon, W. P., and Sougy, J. M. A., 1974, Geology of west Africa and Canary and Cape Verde Islands, in Nairn, A. E. M., and Stehli, F. G., eds., Ocean basins and margins, Volume 2, North Atlantic: New York, Plenum Press, p. 315-390.

Dillon, W. P., and Vedder, J. G., 1973, Structure and development of the continental margin of British Honduras: Geological Society of America Bulletin, v. 84, no. 8, p. 2713-2732.

Dingle, R. V., and Scrutton, R. A., 1974, Continental breakup and the development of post-Paleozoic sedimentary basins around southern Africa: Geological Society of America Bulletin, v. 85, no. 9, p. 1467-1474.

Donovan, D. T., ed., 1968, Geology of shelf seas: Inter-university Geological Congress, 14th, Proceedings, London, Oliver and Boyd, $160 \mathrm{p}$.

Doyle, L. J., and Gorsline, D. S., 1977, Marine geology of Baja California continental borderland, Mexico: American Association of Petroleum Geologists Bulletin, v. 61, no. 6, p. 903-917.

Drilling-DCW, 1975, New lure in Pakistan: Drilling-DCW, April 20, p. 62-65. 
Dufour, J., 1955, Some oil-geological characteristics of Venezuela: World Petroleum Congress, 4th, Rome, 1955, Proceedings, sec. 1, p. 19-36.

Dunn, W. W., Eha, S., and Heikkila, H. H., 1973, North Sea is a tough theater for the oil-hungry industry to explore: $0 i 1$ and Gas Journal, v. 71 , no. 2 , p. 122-128.

Ealey, P. J., 1969, Marine geology of north Brazil--a reconnaissance survey: Urbana, University of Illinois Ph. D. thesis, $65 \mathrm{p}$.

Eckel, E. B., 1959, Geology and mineral resources of Paraguay--a reconnaissance: U.S. Geological Survey Professional Paper 327, 110 p.

Eldholm, O., and Windisch, C. C., 1974, Sediment distribution in the Norwegian-Greenland Sea: Geological Society of America Bulletin, v. 85, no. 11, p. 1661-1676.

Emery, K. O., and Ben-Avraham, Z., 1972, Structure and stratigraphy of China Basin: American Association of Petroleum Geologists Bulletin, v. 56, no. 5, p. 839-859.

Emery, K. O., and others, 1970, Geological structure and some water characteristics of the East China Sea and the Yellow Sea: Petroleum Geology Taiwan, no. 7, p. 243-279.

1975, Continental margin off western Africa--Angola to Sierra Leone: American Association of Petroleum Geologists Bull., v. 59, no. 12 , p. 2209-2265.

Eremenko, N. A., and others, 1970, Map of prospective oil and gas areas of the USSR Shelf: Moscow, Academy of Science, USSR, Ministry of Geology, USSR, Ministry of Oil Industry, USSR, and Azerbaydzhan Academy of Science, scale 1:5,000,000, 3 sheets.

1971, Oil and gas prospects of the shelf of the USSR: World Petroleum Congress, 8th, Moscow, 1971, Proceedings, v. 2, p. 121129.

1973, Geologic structure and oil and gas prospects of USSR continental shelf: American Association of Petroleum Geologists Bulletin, v. 57, no. 2, p. 235-243.

Erentoz, C., and Ternek, Z., 1959, Oil possibilities in the sedimentary basins of Turkey: World Petroleum Congress, 5th, New York, 1959, Proceedings, sec. 1, p. 295-309.

Escher, A., and others, 1970, Tectonic/geologic map of Greenland: Geological Survey of Greenland, scale 1:2,500,000. 
Ewing, E., and others, 1973, Sediment distribution in the oceans--The Atlantic: Geological Society of America Bulletin, v. 84, no. 1, p. 71-88.

Ewing, J. I., and others, 1957a, Geophysical investigations in the eastern Caribbean--Venezuela Basin, Antilles Island Arc, and Puerto Rico Trench: Geological Society of America Bulletin, v. 68, no. 3 , p. 359-378.

1957b, Geophysical investigations in the eastern Caribbean-Trinidad Shelf, Tobago Trough, Barbados Ridge, Atlantic Ocean: Geological Society of America Bulletin, v. 68, no. 7, p. 897-912.

Ewing, M., and Heezen, B. C., 1955, Puerto Rico Trench topographic and geophysical data, in Poldervaart, A., ed., Crust of the earth: Geological Society of America Special Paper 62, p. 255-267.

Ewing M., Ludwig, W. J., and Ewing, J. I., 1963, Geophysical investigations in the submerged Argentina coastal plain, Part 1, Buenos Aires to peninsula Valdez: Geological Society of America Bulletin, v. 74, no. 3, p. 275-291.

Exon, N., 1974, The geological evolution of the southern Taroom Trough and the overlying Surat Basin: Australian Petroleum Exploration Association Journal, v. 14, pt. 1, p. 50-59.

Fairbridge, R. W., ed., 1975, The encyclopedia of world regional geology, Part 1, Western hemisphere; Encyclopedia of earth sciences, Volume 8: Stroudsburg, Penn., Halsted Press, 703 p.

Fedynskiy, V. V., and Levin, L. E., eds. (Billings, M. P., ed., Englishlanguage edition, 1970), The tectonics and oil and gas potential of the marginal and inland seas of the USSR: New York, Lamont-Doherty Geological Observatory of Columbia University, 301 p.

Feininger, T., 1975, Origin of petroleum in the Oriente of Ecuador: American Association of Petroleum Geologists Bulletin, v. 59, no. 7, p. 1166-1175.

Fletcher, B. N., 1975, A new Tertiary basin east of Lundy Island: Quarterly Journal of the Geological Society of London, v. 131, pt. 2, p. 223-225.

Fohs, F. J., 1947, Oil reserve provinces of Middle East and southern Soviet Russia: American Association of Petroleum Geologists Bulletin, v. 31 , no. 8, p. 1372-1383.

Forgotson, J. M., and Corgan, J. X., eds., 1963, Symposium on the petroleum geology of South America: Tulsa Geological Society Digest, v. 31, $271 \mathrm{p}$.

Foster, H. L., 1962, Sedimentary basins and petroleum exploration in Japan: American Association of Petroleum Geologists Bulletin, v. 46 , no. 2 , p. 267. 
Franchetean, J., and LePichon, X., 1972, Marginal fracture zones as structural framework of margins in South Atlantic Ocean: American Association of Petroleum Geologists Bulletin, v. 56, no. 6, p. 9911007.

Franco, A., 1974, Bolivia offers extraordinary possibilities for exploration: Petroleo Internacional, v. 32, no. 9, p. 46-53.

Frazier, S. B., Schwartz, D., Cronk, C., and Choi, S. 0., 1972, Petroleum exploration survey over a portion of the Yellow Sea: International Geology Congress, 24th, Montreal, 1972, Proceedings, sec. 5, p. 135-141.

Freeman, R. N., 1972, Petroleum geology of Subandean Basin of Ecuador, northern Peru, and southern Colombia: American Association of Petroleum Geologists Bulletin, v. 56, no. 3, p. 617-618.

Furrazola-Bermudez, G., and others, 1968, Geology of Cuba: Washington, D.C., U.S. Department of Commerce, Joint Publication Research Service Translation on Cuba, no. 311,207 p.

Gaertner, H. R. V., and Walther, H. W., coordinators, 1971, International geological map of Europe and the Mediterranean region: International Geological Congress--Commission for the Geological Map of the World, Bundesanstalt fuir Bodenforschung and United Nations Educational, Scientific, Cultural Organization, scale 1:5,000,000.

Gaffney, P. D., 1974, The geology of the northwest Europe marine area: Southeast Asia Petroleum Exploration Society, Proceedings, v. 1, p. 64-80.

Gaffney, P. D., Moyes, C. P., and Aling, B., 1976, Economic appraisal of the potential petroleum resources of the Asian Pacific region: Australian Petroleum Exploration Association Journal, v. 16, no. 2, p. 56-62.

Galavis, J. A., and Louder, L. W., 1970, Preliminary studies on geomorphology, geology and geophysics on the continental shelf and slope of northern South America: World Petroleum Congress, 8th, Moscow, 1970, Proceedings, v. 2, p. 107-120.

Galavis, J. A., and Velande, C. H. M., 1967, Geological study and preliminary evaluation of potential reserves of heavy oil of the Orinoco Tar Belt, eastern Venezuelan Basin: World Petroleum Congress, 7 th, Mexico City, 1967, Proceedings, v. 2, p. 229-234.

Gardner, J., 1945, Mollusca of the Tertiary formations of northeastern Mexico: Geological Society of America Memoir 11, 332 p.

Geodekyan, A. A., and others, 1975, Geological-geochemical evaluation of possible oil and gas content of the Bering Sea, the Seas of Okhotsk and Japan, the northwestern Pacific and the Arctic Ocean: World Petroleum Congress, 9th, Tokyo, 1975, Proceedings, v. 2, p. 337346. 
Geological Institute of Dionýz Stúr and United Nations Educational, Scientific, and Cultural Organization, 1973, Tectonic map of the Carpathian Balkan Mountain systems and adjacent areas: Geological Institute of Dionýz Stúr and United Nations Educational, Scientific, and Cultural Organization, scale 1:1,000,000.

Gervasio, F. C., 1973, Geotectonic development of the Philippines, in Coleman, P. J., ed., The western Pacific--island arcs, marginal seas, geochemistry: New York, Crane, Russak \& Co., Inc., p. 307324.

Ghignone, J. I., and De Andrade, G., 1970, General geology and major oil fields of Reconcavo Basin, Brazil, in Halbouty, M. T., ed., Symposium of giant oil and gas fields of the world: American Association of Petroleum Geologists Memoir 14, p. 337-358.

Gill, W. D., 1967, The North Sea Basin: World Petroleum Congress, 7th, Mexico City, 1967, Proceedings, v. 2, p. 211-219.

Ginzberg, A., and others, 1975, Geology of Mediterranean Shelf of Israel: American Association of Petroleum Geologists Bulletin, v. 59, no. 11 , p. 2142-2160.

Gonulden, P., 1970a, An outline of the oil basins of Turkey: $0 i 1$ and Gas Journal, v. 65, no. 33, pt. 1, p. 100-105.

1970b, An outline of the oil basins of Turkey: Oil and Gas Journal, v. 65, no. 34, pt. 2, p. 94-95.

Grantz, A., Holmes, M. L., and Kososki, B. A., 1975, Geologic framework of the Alaskan continental terrace in the Chukchi and Beaufort Seas, In Yorath, C. J., Parker, E. R., and Glass, D. J. eds., Canada's continental margins and offshore petroleum exploration: Canadian Society of Petroleum Geologists Memoir 4, p. 669-699.

Gribi, E. A., Jr., 1974, Petroleum geology of the Moluccas, eastern Indonesia: Southeast Asia Petroleum Exploration Society, Proceedings, v. 1, p. 25-30.

Gringorenko, J. N., and others, 1975, The oil and gas producing basins of the shelves of northeastern Asia, in Yorath, C. J., Parker, E. R., and Glass, D. J., eds., Canada's continental margins and offshore petroleum exploration: Canadian Society of Petroleum Geologists Memoir 4, p. 663-668.

Guatamala, Republic of, 1970, Mapa geologico de la Republica de Guatemala: Instituto Geografico Nacional--Guatemala, scale 1:500,000, 4 sheets.

Guzman, E. J., and Cserna, Z. de, 1963, Tectonic history of Mexico, in Childs, 0. E., and Beebe, B. W., eds., Backbone of the Americas: American Association of Petroleum Geologists Memoir 2, p. 113-129. 
Halbouty, M. T., Maher, J. C., and Lian, H. M., eds., 1976, CircumPacific energy and mineral resources: Circum-Pacific Energy and Mineral Resources Conference, Honolulu, Hawaii, 1974, Proceedings, American Association of Petroleum Geologists Memoir 25, 608 p.

Halbouty, M. T., and others, 1970, World's giant oil and gas fields, geologic factors affecting their formation, and basin classification, Part 1, Giant oil and gas fields, in Halbouty, M. T., ed., Geology of giant petroleum fields: American Association of Petroleum Geologists Memoir 14, p. 502-528.

Haller, J., 1971, Geology of the east Greenland Caledonides: New York, Interscience Publishers, $413 \mathrm{p}$.

Hamilton, W., 1973, Tectonics of the Indonesia region: Geological Society of Malaysia Bulletin 6, p. 3-10.

1974, Map of sedimentary basins of the Indonesia region: U.S. Geological Survey Map I-875-B, scale 1:5,000,000.

Hancock, J. M., and Scholle, P. A., 1975, Chalk of the North Sea, in Woodland, A. W., ed., Petroleum and the continental shelf of northwest Europe, Volume 1: New York, John Wiley and Sons, p. 413428.

Harrington, H. J., 1956, Argentina, in Jenks, W. F., ed., Handbook of South American geology: Geological Society of America Memoir 65, p. 131-165.

1962, Paleogeographic development of South America: American Association of Petroleum Geologists Bulletin, v. 46, no. 10, p. 1773-1814.

Hatfield, W. C., 1958, Colombia's geological features: Petroleum Engineer, v. 30 , no. 2 , p. 21-29.

Hatten, C. W., 1967, Principal features of Cuban geology--discussion: American Association of Petroleum Geologists Bulletin, v. 51, no. 5, p. 780-789.

Hayes, D. E., 1974, Continental margin of western South America, in Burk, C. A., and Drake, C. L., eds., The geology of continental margins: New York, Springer-Verlag, p. 581-590.

Hedberg, H. D., 1950, Geology of the eastern Venezuela Basin (AnzoateguiMonagas-Sucre-eastern Guarico portion): Geological Society of America Bulletin, v. 61, no. 11, p. 1173-1216.

Helu, P. C., Verdugo, V. R., and Barcenas, P. R., 1977, Origin and distribution of Tertiary conglomerates, Veracruz Basin, Mexico: American Association of Petroleum Geologists Bulletin, v. 61, no. 2, p. 207-226. 
Helvig, J., 1972, Stratigraphy, sedimentation, paleogeography, and paleoclimates of Carboniferous ("Gondwana") and Permian of Bolivia: American Association of Petroleum Geologists Bulletin, v. 56, no. 6, p. 1008-1033.

Henderson, G., 1969, Oil and gas prospects in the Cretaceous-Tertiary basin of west Greenland: Grфnlands Geologiske Unders $\phi g e l s e$, Rapp. no. 22 , p. 5-50.

Henderson, G., and Stevens, N. B. H., 1969, Note on oil and gas prospects in west Greenland: Geological Survey of Greenland, Information Circular (unnumbered), $14 \mathrm{p}$.

Hilde, T. W. C., and Wageman, J. M., 1973, Structure and origin of the Japan Sea, in Coleman, P. J., ed., The western Pacific--island arcs, marginal seas, geochemistry: New York, Crane, Russak \& Co., Inc., p. 415-434.

Ho, C. S., 1971, The Tertiary basins of Taiwan: Bulletin of the Geological Survey of Taiwan, no. 23, p. 1-52.

Hogetoorn, D. J., 1967, Jurassic reservoir of the Surat Basin: World Petroleum Congress, 7th, Mexico City, 1967, Proceedings, v. 2, p. 161-170.

Holcombe, T. L., and Matthews, J. E., 1972, Structural fabric of the Venezuela Basin, Caribbean Sea: Geological Society of America Abstracts with Programs, v. 5, no. 7, p. 671-672.

Hopkinson, J. P., and Nysaether, E., 1975, All geologic systems from Permian up represented in North Sea success story: $0 i l$ and Gas Journal, v. 73, no. 33, p. 158-161.

Hoskins, E. G., and Griffiths, J. R., 1971, Hydrocarbon potential of northern and central California offshore, in Cram, I. H., ed., Future petroleum provinces of the United States--their geology and potential: American Association of Petroleum Geologists Memoir 15, v. 1, p. 212-228.

Hospers, J., 1971, The geology of the Niger Delta area, in Delany, F. M., ed., The geology of the East Atlantic continental margins- 4 Africa: Great Britain Institute of Geological Sciences Report 70/16, p. 121-142.

Hotz, E. E., 1963, Petroleum occurrence in the Cretaceous of Venezuela: World Petroleum Congress, 6th, Frankfurt-am-Main, 1963, Proceedings, sec. 1, P. 115-140.

Hubach, H., and others, compilers, 1962, Mapa geologico de Colombia: Ministerio de Minas y Petroleos, scale 1:1,500,000, 1 sheet. 
Imlay, R. W., 1944, Cretaceous formations of Central America and Mexico: American Association of Petroleum Geologists Bulletin, v. 28, no. 8, p. 1077-1195.

India, Geological Survey of, 1963, Tectonic map of India: Geological Survey of India, scale $1: 2,000,000,4$ sheets.

Institut Français du Pétrole, 1974, Principales zones pétrolières du Venezuela: Institut Français du Pétrole, Texte and Annexe 1, 2 and 3.

International Petroleum Consultants, 1974a, Structural/prospect map of the northern part of central Siberia (East Siberian Platform): Review of Sing-Soviet 0il, v. 9, no. 7, Enclosure 1, scale $1: 2,500,000 . \underline{1}$

1974b, Turkey, Sypgpsis 1973: International Petroleum Consultants, scale $1: 2,000,000.1$

1975a, Irkutsk Amphitheater: Review of Sino-Soviet 0il, v. 10, no. 6, Enclosure 2, scale 1:5,000,000.

1975b, Japan and South Korea, synopsis first half, 1975 ;

International Petroleum Consultants, scale $1: 2,000,000.1$

1975c, New Zealand, North Island, synopsis first half, 7975 :

International Petroleum Consultants, scale $1: 1,000,000$. -

1975d, New Zealand, South Island, synopsis first half, 1975:

International Petroleum Consultants, scale $1: 1,000,000$. If

1975e, Structural/prospect map of the northern part of western Siberia (map of gas figlds): Review of Sino-Soviet 0il, v. 10, no. 8 , scale $1: 2,500,000$.

1976, South Vietnam, synopsis 1975: International Petroleum Consultants, scale $1: 2,000,000 . \underline{1}$

Iran, Geological Survey of, 1973, Tectonic map of Iran: Geological Survey of Iran, scale 1:2,500,000.

Irizany, 0. B., 1960, Que ofrece la Tierra del Fuego: Petroleo Interam, v. 18 , no. 5 , p. 36-42.

Jacobs, C., Burg1, H., and Conley, D. I., 1963, Backbone of Colombia, in Childs, O. E., and Beebe, B. W., eds., Backbone of the Americas: American Association of Petroleum Geologists Memoir 2, p. 62-72.

Jansa, L. F., and Wade, J., 1975a, Geology of the continental margin off Nova Scotia and Newfoundland, in Van Der Linden, W. J. M., and Wade, J. A., eds., Offshore geology of eastern Canada: Geological Survey of Canada Paper 74-30, v. 2, p. 51-106.

If Available only from Petroconsultants, SA, 2 Rue Vallin - 1211

Geneva 11, Switzerland. 
1975b, Paleogeography and sedimentation in the Mesozoic and Cenozoic southeastern Canada, in Yorath, C. J., Parker, E. R., and Glass, D. J., eds., Canada's continental margins and offshore petroleum exploration: Canadian Society of Petroleum Geologists Memoir 4, p. 79-102.

Japan, Geological Survey of, 1964, Geological map of Japan: Geological Survey of Japan, scale 1:2,000,000.

Japanese Delegation, 1971a, Case histories of oil fields along the western margin of Lake Hachirogata, northwestern Honshu, Japan, in Case histories of oil and gas fields in Asia and the Far East (3rd series): United Nations Economic Committee for Asia and Far East, Mineral Resources Development Series, no. 37, p. 58-61.

1971b, Case history of the Hirakida gas field, northwestern Honshu, Japan, in Case histories of oil and gas fields in Asia and the Far East (3rd series): United Nations Economic Committee for Asia and Far East, Mineral Resources Development Series, no. 37, p. 68-71.

1971c, Case history of the Minami-aga oil field, northwestern Honshu, Japan, in Case histories of oil and gas fields in Asia and the Far East (3rd series): United Nations Economic Committee for Asia and Far East, Mineral Resources Development Series, no. 37, p. 72-76.

1971d, Case history of the Nakajo-Shintainai gas field, northwestern Honshu, Japan, in Case histories of oil and gas fields in Asia and the Far East (3rd series): United Nations Economic Committee for Asia and Far East, Mineral Resources Development Series, no. 37, p. 62-64.

1971e, Case history of the Yoshii gas field, northwestern Honshu, Japan, in Case histories of oil and gas fields of Asia and the Far East (3rd series): United Nations Economic Committee for Asia and Far East, Mineral Resources Development Series, no. 37, p. 65-67.

Jarrin, A., 1974, Exploration and development of new hydrocarbon resources in Pacific Basins of Ecuador: American Association of Petroleum Geologists Bulletin, v. 58, no. 7, p. 1442 .

Javanaphet, J. C., 1969, Geological map of Thailand: Thailand Department of Mineral Resources, scale 1:1,000,000.

Jenks, W. F., ed., 1956, Handbook of South American geology: Geological Society of America Memoir 65, 378 p.

Johnson, G. L., McMillan, N. J., and Egloff, J., 1975, East Greenland continental margin, in Yorath, C. J., Parker, E. R., and Glass, D. J., eds., Canada's continental margins and offshore petroleum exploration: Canadian Society of Petroleum Geologists Memoir 4, p. 205-224. 
Kailasam, L. N., 1976, Geophysical studies of the major sedimentary basins of the Indian craton, their deep structural features and evolution: Unpublished, $20 \mathrm{p}$.

Kamen-Kaye, M., 1970, Geology and productivity of Persian Gulf synclinorium: American Association of Petroleum Geologists Bulletin, v. 54, no. 12, p. 2371-2394.

Karig, D. E., 1973, Comparison of island arc-marginal basin complexes in the northwest and southwest Pacific, in Coleman, P. J., ed., The western Pacific--island arcs, marginal seas, geochemistry: New York, Crane, Russak and Co., Inc., p. 355-364.

Katz, H. R., 1968, Potential oil formations in New Zealand and their stratigraphic position as related to basin evolution: New Zealand Journal of Geology and Geophysics, v. 11, no. 5, p. 1077-1133.

1971, Continental margin in Chile--its tectonic style compressional or extensional: American Association of Petroleum Geologists Bulletin, v. 55, no. 10, p. 1753-1758.

1974a, Margins of the southwest Pacific, in Burk, C. A., and Drake, C. L., eds., The geology of continental margins: New York, SpringerVerlag, p. 549-565.

1974b, Offshore petroleum potential in New Zealand: Australian Petroleum Exploration Association Journal, v. 14, pt. 1, p. 3-13.

Kear, D., 1967, The Kapuni gas-condensate field, New Zealand--a case study, in Case histories of oil and gas fields in Asia and the Far East (2nd series): United Nations Economic Committee for Asia and Far East, Mineral Resources Development Series, no. 29, p. 86-91.

Kent, P. E., 1969, The geological framework of petroleum exploration in Europe and North Africa and the implications of continental drift hypothesis, in Hepple, P., ed., The exploration for petroleum in Europe and North Africa: London, Institute of Petroleum, p. 3-17.

1974, Continental margin of East Africa--a region of vertical movement, in Burk, C. A., and Drake, C. L., eds., The geology of continental margins: New York, Springer-Verlag, p. 313-320.

1975, The tectonic development of Great Britain and the surrounding seas, in Woodland, A. W., ed., Petroleum and the continental shelf of northwest Europe, volume 1: New York, John Wiley and Sons, p. $3-28$.

Kent, P. E., and Perry, J. T. O'B., 1973, The development of the Indian Ocean margin in Tanzania, in Blant, G., ed., Bassins sédimentaires du littoral Africain, part $\frac{2}{2}$, Littoral austral et oriental (Montreal, 1972): Paris, Union Internationale des Sciences Geologiques Association des Services Geologiques Africains, p. 113-131. 
Kent, P. E., and Warman, H. R., 1972, An environmental review of the world's richest oil-bearing region--the Middle East: International Geological Congress, 24th, Montreal, 1972, Proceedings, sec. 5, p. 142-152.

Khain, V. E., and Seslavinsky, K. B., 1973, Some basic problems of structure and tectonic history of the northwestern segment of the Pacific mobile belt, in Coleman, P. J., ed., The western Pacific-island arcs, marginal seas, geochemistry: New York, Crane, Russak and Co., Inc., p. 389-406.

Khudoley, K. M., 1967, Principal features of Cuban geology: American Association of Petroleum Geologists Bulletin, v. 51, no. 5, p. 668677.

King, L. H., and Maclean, B., 1976, Geology of the Scotian Shelf and adjacent areas, in King, L. H., and MacLean, B., eds., Geology of the Scotian Shelf: Ottawa, Canadian Hydrographic Service-Department of the Environment, and the Geological Survey of Canada-Department of Energy, Mines and Resources, Marine Sciences Paper 7, Geological Survey of Canada Paper 74-31, p. 1-31.

King, R. E., 1975a, Canadian Arctic promises future gas and oil supply: World Oil, v. 181, no. 7, p. 53-59.

1975b, Petroleum exploration and production in Europe in 1974: American Association of Petroleum Geologists Bulletin, v. 59, no. 10, p. 1870.

Kobayashi, K., and Toda, M., 1965, Wakimoto offshore structure discovered by submarine topographic survey in the Japan Sea, in Case histories of oil and gas fields in Asia and the Far East (2nd series): United Nations Economic Committee for Asia and Far East, Mineral Resources Development Series, no. 29, p. 81-85.

Koch, E., 1959, Geology of the Maquia oil field in eastern Peru and its regional setting: World Petroleum Congress, 5th, New York, 1959, Proceedings, sec. 1, p. 591-601.

Koldewijn, B. W., 1958, Sediments of the Paria-Trinidad Shelf, reports of the Orinoco Shelf expedition: The Hague, Mouton and Co., v. 3, $109 \mathrm{p}$.

Korea, Geological Survey of, 1972, Isotope ages and geological map of Korea: Geological Survey of Korea, scale 1:2,000,000.

Kornicker, L. S., and Bryant, W. R., 1969, Sedimentation on continental shelf of Guatemala and Honduras, in McBirney, A. R., ed., Tectonic relations of northern Central America and the western Caribbean, The Bonacca Expedition: American Association of Petroleum Geologists Memoir 11, part 2, p. 244-257.

Kostylev, Y. N., and Burlin, Y. K., 1966, Geologic evolution of the Anadyr' Depression: Akademii Nauk SSSR, Doklady, v. 166, no. 5, p. 1177-1179. 
Kowsmann, R., Leyden, R., and Francisconi, 0., 1977, Marine seismic investigations, southern Brazil margin: American Association of Petroleum Geologists Bulletin, v. 61, no. 4, p. 546-557.

Kraft, J. C., Sheridan, R. E., and Maisano, M., 1971, Time-stratigraphic units and petroleum entrapment models in Baltimore Canyon Basin of Atlantic continental margin geosyncline: American Association of Petroleum Geologists Bulletin, v. 55, no. 5, p. 658-679.

Kraus, G. P., and Laws, R. A., 1974a, Regional geology of Bonaparte Gulf--Timor Sea area of northwest Australia, Part 1: 0il and Gas Journal, v. 72 , no. 46, p. 98-101.

1974b, Regional geology of Bonaparte Gulf-Timor Sea area of northwest Australia, Part 2: Oil and Gas Journal, v. 72, no. 47, p. 160-162.

Kumar, N., 1978, Sediment distribution in western Atlantic off northern Brazil--structural controls and evolution: American Association of Petroleum Geologists Bulletin, v. 62, no. 2, p. 273-294.

Kummel, B., 1948, Geological reconnaissance of the Contamana region, Peru: Geological Society of America Bulletin, v. 59, no. 12, pt. 1, p. 1217-1265.

Lamb, W. C., and Truitt, P., 1963, The petroleum geology of the Santa Cruz area, Bolivia: World Petroleum Congress, 6th, Frankfurt-amMain, 1963, Proceedings, sec. 1, p. 573-594.

Landes, K. K., 1959, Petroleum geology (2nd ed): New York, John Wiley and Sons, Inc., $443 \mathrm{p}$.

Laroche, P. J., 1975, The geological setting of the Gulf of St. Lawrence, in Yorath, C. J., Parker, E. R., and Glass, D. J., eds., Canada's continental margins and offshore petroleum exploration: Canadian Society of Petroleum Geologists Memoir 4, p. 892.

Lattimore, R. K., Weeks, L. A., and Mordock, L. W., 1971, Marine geophysical reconnaissance of continental margin north of Paria Peninsula, Venezuela: American Association of Petroleum Geologists Bulletin, v. 55, no. 10, p. 1719-1729.

Lebedev, L. I., and others, 1975, Sedimentary basins of the submarine margin of north Europe and their oil and gas prospects, in Yorath, C. J., Parker, E. R., and Glass, D. J., eds., Canada's continental margins and offshore petroleum exploration: Canadian Society of Petroleum Geologists Memoir 4, p. 257-265.

Leslie, R. B., Evans, H. J., and Knight, C. L., eds., 1976, Economic geology of Australia and Papua New Guinea--vol. 3, Petroleum: Parkville, Victoria, Australia, the Australasian Institute of Mining and Metallurgy, Monograph Series No. 7, 541 p.

Leyden, R., Bryan, G., and Ewing, M., 1972, Geophysical reconnaissance on African Shelf; 2. Margin sediment from Gulf of Guinea to Walvis Ridge: American Association of Petroleum Geologists Bulletin, v. 56 , no. 4, p. 682-693. 
Leyden, R., Ludwig, W. J., and Ewing, M., 1971, Structure of continental margin off Punta del Este, Uruguay, and Rio de Janeiro, Brazil: American Association of Petroleum Geologists Bulletin, v. 55, no. 12, p. 2161-2173.

Li, W. Y. L., 1970, Geologic map of the Republic of China: Chinese Petroleum Corp., scale 1:4,000,000.

1971, An outline of the petroleum geology on the mainland of China: Petroleum Geology of Taiwan, no. 9, p. 205-225 (English trans. Chaing, D. M., Esso Exploration, Houston, Tex.).

Link, W. K., 1959, The sedimentary framework of Brazil: World Petroleum Congress, 5th, New York, 1959, Proceedings, section 1, p. 901-923.

Lloyd, J. J., 1963, Tectonic history of the south Central American orogen, in Childs, O. E., and Beebe, B. W., eds., Backbone of the Americas: American Association of Petroleum Geologists Memoir 2, p. 88-112.

Lofting, M. J. W., Crostella, A., and Halse, J. W., 1975, Exploration results and future prospects in the northern Australasian region: World Petroleum Congress, 9th, Tokyo, 1975, Proceedings, v. 3, p. 65-81.

Lomnitz, C., 1962, Gravity measurements in the central valley of Chile: World Petroleum Congress, 5th, New York, 1962, Proceedings, sec. 1, p. 801-814.

Ludwig, W. J., Ewing, J. I., and Ewing, M., 1968, Structure of Argentine continental margin: American Association of Petroleum Geologists Bulletin, v. 52, no. 12, p. 2337-2368.

Ludwig, W. J., Murauchi, S., and Houtz, R. E., 1975, Sediments and structure of the Japan Sea: Geological Society of America Bulletin, v. 86 , no. 5 , p. $651-664$.

McBirney, A. R., 1963, Geology of a part of the central Guatemalan Cordillera: University of California, Publications in Geological Sciences, v. 38, p. 177-242.

McCaslin, J. C., 1972, Europe's North Sea Basin has interesting neighbors: 0 il and Gas Journal, v. 70, no. 50, p. 155.

1974, Mexican find emphasizes need for deeper look: 0 il and Gas Journal, v. 72 , no. 46, p. 97.

McCrossan, R. G., ed., 1973, The future petroleum provinces of Canada-their geology and potential: Canadian Society of Petroleum Geologists Memoir 1, $720 \mathrm{p}$.

McCrossan, R. G., and Glaister, R. P., eds., 1964, Geological history of western Canada (Atlas): Calgary, Alberta Society of Petroleum Geologists. 
McDowell, A. N., 1975, What are the problems in estimating the oil potential of a basin?: $0 i 1$ and Gas Journal, v. 73, no. 23, p. 8590.

McMaster, R. I., Christofferson, E., and Ashraf, A., 1975, Structural framework of continental shelf and slope of' southwestern Sierra Leone, West Africa: American Association of Petroleum Geologists Bulletin, v. 59, no. 11, p. 2161-2171.

McMaster, R. I., DeBoer, J., and Ashraf, A., 1970, Magnetic and seismic reflection studies on continental shelf off Portuguese Guinea, Guinea and Sierra Leone, West Africa: American Association of Petroleum Geologists Bulletin, v. 54, no. 1, p. 158-168.

Marlow, M. S., and others, 1975, Structure and evolution of the Bering Sea Shelf, in Yorath, C. J., Parker, E. R., and Glass, D. J., eds., Canada's continental margins and offshore petroleum exploration: Canadian Society of Petroleum Geologists Memoir 4, p. 893.

Martinez, A. R., 1966, Our gift, our oil: The Netherlands, N. V. Drukkerij, D. Reidel-Dordrecht, 199 p.

1972, Los recursos de hidrocarburos de Venezuela: Memoria Cuarto Congreso Geologico Venezolano, v. 5, no. 5, p. 2687-2727.

Meissner, C. R., Jr., and Rahman, H., 1973, Distribution, thickness and 1ithology of Paleocene rocks in Pakistan: U.S. Geological Survey Professional Paper 716E (Plate 1).

Meister, E. M., and Aurich, N., 1972, Geologic outline and oil fields of Sergipe Basin, Brazil: American Association of Petroleum Geologists Bulletin, v. 56, no. 6, p. 1034-1047.

Mencher, E., and others, 1953, Geology of Venezuela and its oil fields: American Association of Petroleum Geologists Bulletin, v. 37, no. 4 , p. 690-777.

Meng, C. Y., and Chou, J. T., 1975, The petroliferous Taiwan basins in the framework of the western Pacific Ocean: Chinese Petroleum Corp., 12 p.

Mesner, J. C., and Wooldridge, L. C. P., 1964, Maranhão Paleozoic basin and Cretaceous coastal basins, north Brazil: American Association of Petroleum Geologists Bulletin, v. 48, no. 9, p. 1475-1512.

Meyerhoff, A. A., 1970, Developments in mainland China 1949-1968: American Association of Petroleum Geologists Bulletin, v. 54, no. 8, p. 1567-1580.

1972a, Russians look hard at the Anadyr' Basin: 0 il and Gas Journal, v. 70 , no. 43, pt. 1, p. 124-129. 
1972b, Russians look hard at the Anadyr' Basin: 0 il and Gas Journal, v. 70, no. 44, pt. 2, p. 84-89.

1973a, Geopolitical implication of Russian and Chinese petroleum, in Cameron, V. S., ed., Exploration and economics of the petroleum industry, volume J.I: New York, Matthew Bender and Co., p. 79-127.

1973b, Origin of Arctic and North Atlantic Oceans, in Pitcher, $M$. G., ed., Arctic geology: American Association of Petroleum Geologists Memoir 19, p. 562-582.

Meyerhoff, H. A., and Meyerhoff, A. A., 1973, Arctic geopolitics, in Pitcher, M. G., ed., Arctic geology: American Association of Petroleum Geologists Memoir 19, p. 646-670.

Meyerhoff, A. A., and Willums, J. 0., 1976, Petroleum geology and industry of the People's Republic of China: United Nations ESCAP, CCOP Technical Bulletin, v. 10, 212 p.

Miller, B. M., and others, 1975, Geological estimates of undiscovered recoverable oil and gas resources in the United States: U.S. Geological Survey, Circular 725, 78 p.

Miller, D. J., Payne, T. G., and Gryc, G., 1959, Geology of possible petroleum provinces in Alaska: U.S. Geological Survey Bulletin 1094, $131 \mathrm{p}$.

Miller, J. B., 1962, Tectonic trends in Sierra de Perija and adjacent parts of Venezuela and Colombia: American Association of Petroleum Geologists Bulletin, v. 46, no. 9, p. 1565-1595.

Miller, J. B., and others, 1958, Habitat of oil in the Maracaibo Basin, Venezuela, in Weeks, L. G., ed., Habitat of oil, a symposium: American Association of Petroleum Geologists, p. 601-640.

Montadert, L., and others, 1974, Continental margins of Galacia-Portugal and Bay of Biscay, in Burk, C. A., and Drake, C. L., eds., The geology of continental margins: New York, Springer-Verlag, p. 323342.

Moody, G. B., ed., 1961, Petroleum exploration handbook: New York, McGraw-Hill, 25 chapters.

Moody, J. D., 1964, Petroleum development in Africa in 1963: American Association of Petroleum Geologists Bulletin, v. 48, no. 10, p. 1622-1665.

Moore, G. W., and CastilJ.o, L. D., 1974, Tectonic evolution of the southern Gulf of Mexico: Geological Society of America Bulletin, v. 85, no. 4, p. 607-618.

Morales, L. G., 1959, General geology and oil possibilities of the Amazonas Basin, Brazil: World Petroleum Congress, 5th, New York, 1959, Proceedings, sec. 1, p. 925-942. 
Murphy, R. W., 1975, Tertiary basins of southeast Asia: Southeast Asia Petroleum Exploration Society, Proceedings, v. 2, p. 1-36.

Murray, J. W., and Tiffin, D. L., 1974, Patterns of deformation, sedimentation and tectonism southwestern Canadian continental margin: Société Géologique de Belgique, Annales, v. 97, no. 1, p. 169-183.

Nalivkin, V. D., ed.-in-chief, 1969, Tectonic map of oil and gas deposits of USSR: USSR, Ministry of Geology, scale 1:2,500,000, 16 sheets.

Naylor, D., and Mounteney, S. N., 1975, Geology of the northwest European continental shelf: London, Graham, Trotman, Dudley, Ltd., v. 1, $162 \mathrm{p}$.

Neprochnov, Y. P., Neprochnova, A. F., and Mirlin, Y. G., 1972, Deep structure of Black Sea Basin, in Degans, E. T., and Ross, D. A., eds., The Black Sea--geology, chemistry, and biology: American Association Petroleum Geologists Memoir 20, p. 35-49.

Newe11, N. D., 1949, Geology of the Lake Titicaca region, Peru and Bolivia: Geological Society of America Memoir 36, 111 p.

New Zealand Geological Survey, 1958, Geological map of New Zealand: New Zealand Geological Survey, scale 1:2,000,000.

1972a, Geological map of New Zealand, North Island: New Zealand Geological Survey, scale 1:1,000,000.

1972b, Geological map of New Zealand, South Island: New Zealand Geological Survey, scale 1:1,000,000.

Nicaragua, Republica de, 1973, Republica de Nicaragua--mapa geologico: Instituto Geografico Nacional, Nicaragua, scale 1:1,000,000, 1 sheet.

Noe-Nygaard, A., 1974, Cenozoic to recent volcanism in and around the North Atlantic Basin, in Nairn, A. E. M., and Stehli, F. G., eds., The ocean basins and margins, Volume 2, The north Atlantic: London, Plenum Press, p. 391-443.

Notestein, F. B., Hubman, C. W., and Bowler, J. W., 1944, Geology of the Barco Concession, Republic of Colombia, South America: Geological Society of America Bulletin, v. 55, no. 10, p. 1165-1216.

Nygren, W. E., 1950, Bolivar geosyncline of northwestern South America: American Association of Petroleum Geologists Bulletin, v. 34, no. 10, p. 1998-2006.

Offshore, 1974, Subsea oil off Chinese coast fires up geopolitical arena: Offshore, v. 34, no. 7, p. 184-185.

1975, Indian Ocean: Offshore, v. 35, no. 4, p. 124-126. 
Oil and Gas Journal, 1970a, An outline of the oil basins of Turkey: Oil and Gas Journal, v. 68, no. 33, part 1, p. 100-105.

1970b, An outline of the oil basins of Turkey: 011 and Gas Journal, v. 68, no. 34, part 2, p. 94-95.

1974a, Japanese have new oil target--promising Sakhalin Island:

Oil and Gas Journal, v. 72, no. 23, p. 94-96.

1974b, Russia looks at deep drilling in Fergana Valley: 011 and Gas Journal, v. 72, no. 46, p. 107.

Oliveira, A. I. de, 1956, Brazil, in Jenks, W. F., ed., Handbook of South American geology: Geological Society of America Memoir 65, p. 1-62.

Ovaesov, G. P., and others, 1975, Palaeodeltaic sediments and methods of petroleum exploration in the USSR: World Petroleum Congress, 9th, Tokyo, 1975, Proceedings, v. 2, p. 229-238.

Ovcharenko, A. V., and Sevost'yanov, K. M., 1975, Oil-gas prospects and plans for further exploration in Kamchatka: Petroleum Geology, v. 12, no. 5, p. 535-537.

Padula, E., and Mingramm, A., 1963, The fundamental geological pattern of the Chaco-Parana Basin (Argentina) in relation to its oil possibilities: World Petroleum Congress, 6th, Frankfurt-am-Main, 1963, Proceedings, sec. 1, p. 293-310.

Parke, M. L., and others, 1971, Structural framework of continental margin in South China Sea: American Association of Petroleum Geologists Bulletin, v. 55, no. 5, p. 723-751.

Paul, D. D., and Lian, H. M., 1975, Offshore Tertiary basins of southeast Asia, Bay of Bengal to South China Sea: World Petroleum Congress, 9 th, Tokyo 1975, Proceedings, v. 3, p. 107-121.

Pegrum, R. M., Rees, G., and Naylor, D., 1975, Geology of the northwest European continental shelf: London, Graham, Trotman, Dudley, Ltd., v. 2, 225 p.

Ponlahan, P., 1973, 0il-gas basins of Indochina: Thailand, Department of Mineral Resources, Mineral Fuels Division, scale 1:5,000,000.

Ponte, F. C., Fonseca, J. D. R., and Morales, R. G., 1977, Petroleum geology of eastern Brazilian continental margin: American Association of Petroleum Geologists Bulletin, v. 61, no. 9, p. 1470-1482.

Portugal Direccao Geral de Minas e Servicos Geologicos, 1972, Carta tectonica de Portugal: Direccao Geral de Minas e Servicos Geologicos, scale $1: 1,000,000$.

Powel1, C. McA., and Conaghan, P. J., 1975, Tectonic models of the Tibetan plateau: Geology, v. 3, no. 12, p. 727-731. 
Powell, T. G., and McKirdy, D. M., 1975, Crude oil composition in Australia and Papua, New Guinea: American Association of Petroleum Geologists Bulletin, v. 59, no. 7, p. 1176-1197.

Power, P. E., and Devine, S. B., 1970, Surat Basin, Australia-subsurface stratigraphy, history and petroleum: American Association of Petroleum Geologists Bulletin, v. 54, no. 12, p. 2410-2437.

Querol, R., 1966, Regional geology of the Spanish Sahara, in Reyre, D., ed., Bassins sédimentaires du littoral Africain, pt. I, Littoral Atlantique (New Delhi, 1964): Paris, Union Internationale des Sciences Géologiques Association des Services Géologiques Africains, p. 27-38.

1969, Petroleum exploration in Spain, in Hepple, P., ed., The exploration for petroleum in Europe and North Africa: London, Institute of Petroleum, p. 49-72.

Rahman, H., 1963, Geology of petroleum in Pakistan: World Petroleum Congress, 6th, Frankfurt-am-Main, 1963, Proceedings, sec. 1, p. 659-683.

Raju, A. T. R., 1968, Geological evolution of Assam and Cambay Tertiary basins of India: American Association of Petroleum Geologists Bulletin, v. 52, no. 12, p. 2422-2437.

Ramakotaiah, G., and Avasthi, D. N., 1974, The status of geophysical knowledge in the east coast and eastern basins of India: Australian Petroleum Exploration Association Journal, v. 14, pt. 1, p. 42-44.

Rao, V. R., 1973, Pre-Cambrian basement depths in some sedimentary basins of India: Geophysical Research Bulletin, v. 11, no. 4, p. 267-272.

Ray, K. K., and Acharyya, S. K., 1976, Concealed Mesozoic-Cenozoic Alpine Himalayan geosyncline and its petroleum possibilities: American Association of Petroleum Geologists Bulletin, v. 60, no. 5, p. 794-808.

Rayner, J. M., 1969, Governmental activities in petroleum exploration: Australian Petroleum Exploration Association Journal, v. 9, pt. 2, p. $23-30$.

Redfield, A. H., 1923, The petroleum possibilities of Costa Rica: Economic Geology, v. 18, no. 4, p. 354-381.

Reedman, A. J., and Um, S. H., 1975, The geology of Korea: Geological and Mineral Institute of Korea, $139 \mathrm{p}$.

Renard, V., and Mascle, J., 1974, Eastern Atlantic continental margins-various structural and morphological types, in Burk, C. A., and Drake, C. L., eds., The geology of continental margins: New York, Springer-Verlag, p. 285-291. 
Renz, H. H., 1942, Stratigraphy of northern South America, Trinidad, and Barbados: American Scientific Congress, 8th, Washington, D. C., 1940, Proceedings, v. 4, p. 513-571.

Renz, H. H., and others, 1958, The eastern Venezuelan Basin, in Weeks, L. G., ed., Habitat of oil, a symposium: Tulsa, Okla., American Association of Petroleum Geologists, p. 551-600.

Republica Dominicana, 1967, Mapa geologico preliminar: Organizacion de los Estados Americanos, scale 1:250,000, 1 sheet.

Reyre, D., 1964, Particularités géologiques des bassins côtiers de I'Ouest Africain, in Reyre, D., ed., Bassins sédimentaires du littoral Africain, Part 1, Littoral Atlantique (New Delhi, 1964): Paris, Union Internationale des Sciences Géologiques Association des Services Géologiques Africains, p. 275-284.

1966, Histoire géologique du bassin de Douala (Cameroun), in Reyre, D., ed., Bassins sedimentaires du littoral Africain, Part 1, Littoral Atlantique (New Delhi, 1964): Paris, Union Internationale des Sciences Géologiques Association des Services Géologiques Africains, p. 143-161.

Richards, H. G., 1963, Stratigraphy of earliest Mesozoic sediments in southeastern Mexico and western Guatemala: American Association of Petroleum Geologists Bulletin, v. 47, no. 10, p. 1861-1870.

Richards, K. A., and Hopkins, B. M., 1971, Offshore exploration for petroleum in the Gippsland, Bass and Otway Basins, southeastern Australia, in Case histories of oil and gas fields in Asia and the Far East (3rd series): United Nations Economic Committee for Asia and Far East, Mineral Resources Development Series, no. 37, p. 1328 .

Robb, J. P., 1971, Structure of continental margins between Cape Rhir and Cape Sim, Morocco, northwest Africa: American Association of Petroleum Geologists Bulletin, v. 55, no. 5, p. 643-651.

Roberts, D. G., and Caston, V. N. D., 1975, Petroleum potential of the deep Atlantic Ocean: World Petroleum Congress, 9th, Tokyo, 1975, Proceedings, v. 2, p. 281-298.

Robertson Research International News, 1975, Petroleum prospects in the Philippines: Robertson Research International News, Issue 2, p. 3.

Robinson, E., and Cambray, F. W., 1971, Physiography of the sea floor east of Jamaica, in Symposium on investigations and resources of the Caribbean Sea and adjacent regions: United Nations Educational, Scientific, Cultural Organization, Paris, 1971, p. 285-289. 
Rod, E., 1959, West end of Serrania del Interior, eastern Venezuela: American Association of Petroleum Geologists Bulletin, v. 43, no. 4, p. 772-789.

Ronnevik, H., and others, 1975, The geology of the Norwegian continental sielf, in Woodland, A. W., ed., Petroleum and the continental shelf of northwest Europe, Volume 1: New York, John Wiley and Sons, p. 117-129.

Ross, D. A., 1974, The Black Sea, in Burk, C. A., and Drake, C. L., eds., The geology of continental margins: New York, SpringerVerlag, p. 669-682.

Ross, D. A., Uchupi, E., and Bowin, C. 0., 1972, Shallow structure of Black Sea, in Degens, E. T., and Ross, D. A., eds., The Black Sea-geology, chemistry and biology: American Association of Petroleum Geologists Memoir 20, p. 11-34.

Ross, D. A., and Uchupi, E., 1977, Structure and sedimentary history of southeastern Mediterranean Sea- $\mathrm{N} 11$ le Cone area: American Association of Petroleum Geologists Bulletin, v. 61, no. 6, p. 872-902.

Rudd, E. A., and Kear, D., 1966, Petroleum developments in southwest Pacific region during 1965: American Association of Petroleum Geologists Bulletin, v. 50, no. 8, p. 1782-1791.

Ruegg, W., 1964, The productive and promising oil basins of Peru: Vereinigung Schweizerischer Petroleum-Geologen und Ingenieure, v. 30 , no. 79 , p. 8-25.

Salso, J. H., 1966, La Cuenca de Macachin, Provincia de la Pampa, Nota Preliminar: Revista Asociacion Geologica Argentina, v. 21, no. 2, p. 107-117.

Salvador, A., and Hotz, E. E., 1963, Petroleum occurrence in the Cretaceous of Venezuela: World Petroleum Congress, 6th, Frankfurt-am-Main, 1963, Proceedings, sec. 1, p. 115-140.

Sander, N. J., Humphrey, W. E., and Mason, J. F., 1975, Tectonic framework of southeast Asia and Australia--Its significance in the occurrence of petroleum: World Petroleum Congress, 9th, Tokyo, 1975, Proceedings, v. 3, p. 83-105.

Sanford, R. M., and Lange, F. W., 1960, Basin-study approach to oil evaluation of Parana miogeosyncline, south Brazil: American Association of Petroleum Geologists Bulletin, v. 44, no. 8, p. 1316-1370.

Sanz, R., 1967, Ayoluengo Field, southwest Cantabrian Basin, north central Spain: World Petroleum Congress, 7th, Mexico City, 1967, Proceedings, v. 2, p. 251-258. 
Sarkisyan, S. G., Politykina, M. A., and Chilingarian, G. V., 1973, Effect of post-sedimentation processes on carbonate reservoir rocks in Volga-Urals region, USSR: American Association of Petroleum Geologists Bulletin, v. 57, no. 7, p. 1305-1313.

Sastri, V. V., and others, 1972, Poorly explored sedimentary basins of India, in Proceedings of the Fourth Symposium on the Development of Petroleum Resources of Asia and the Far East: United Nations Economic Committee for Asia and Far East, Mineral Resources Development Series 41, v. 1, p. 381-406.

1973, Stratigraphy and tectonics of sedimentary basins on east coast of peninsular India: American Association of Petroleum Geologists Bulletin, v. 57, no. 4, p. 655-678.

1974, Evolution of the Mesozoic sedimentary basins on the east coast of India: Australian Petroleum Exploration Association Journal, v. 14, pt. 1, p. 29-41.

Schlee, J., and others, 1974, Shallow structure and stratigraphy of Liberian continental margin: American Association of Petroleum Geologists Bulletin, v. 58, no. 4, p. 708-728.

Schott, W., Branson, J. C., and Turpie, A., 1975, Petroleum potential of the deep-water regions of the Indian Ocean: World Petroleum Congress, 9th, Tokyo, 1975, Proceedings, v. 2, p. 319-335.

Schwade, I. T., 1962, Petroleum geology of coastal Peru and Ecuador: American Association of Petroleum Geologists Bulletin, v. 46, no. 2, p. 279.

Seibold, E., and Hinz, K., 1974, Continental slope construction and destruction, west Africa, in Burk, C. A., and Drake, C. L., eds., The geology of continental margins: New York, Springer-Verlag, p. 179-196.

Semenovich, V. N., and Erofeev, N. S., 1971, New oil and gas regions of the USSR and their prospects: World Petroleum Congress, 8th, Moscow, 1971, Proceedings, v. 2, p. 293-300.

Semenovich, V. N., Gramberg, I. S., and Nesterov, I. I., 1973, 0 il and gas possibilities in the Soviet Arctic, in Pitcher, M. G., ed., Arctic geology: American Association of Petroleum Geologists Memoir 19, p. 194-203.

Shabad, T., and Mote, V. L., 1977, Gateway to Siberian resources (The BAM): New York, John Wiley \& Sons, 189 p.

Sheldon, R. A., 1973, Stratigraphy and petroleum prospects of southwestern Cebu, Philippines: American Association of Petroleum Geologists Bulletin, v. 57, no. 7, p. 1343-1347. 
Shepard, F. P., 1973, Sea floor off Magdalena Delta and Santa Marta area, Colombia: Geological Society of America Bulletin, v. 84, no. 6, p. 1955-1972.

Sheridan, R. E., 1974, Atlantic continental margin of North Americz, in Burk, C. A., and Drake, C. L., eds., The geology of continental margins: New York, Springer-Verlag, p. 391-407.

Sheridan, R. E., and Drake. C. L., 1968, Seaward extension of the Canadian Appalachians: Canadian Journal of Earth Sciences, v. 5, no. 3, p. 337-373.

Sheridan, R. E., and Osburn, W. L., 1975, Marine geological and geophysical studies of the Florida-Blake Plateau-Bahamas area, in Yorath, C. J., Parker, E. R., and Glass, D. J., eds., Canada's continental margins and offshore petroleum explorations: Canadian Society of Petroleum Geologists Memoir 4, p. 9-31.

Sherwin, D. F., 1975, Canada's east coast petroleum potential only been scratched: 0il and Gas Journal, v. 73, no. 17, p. 100-104.

Siller, C. W., 1967, Exploration leading to the discovery of the Mereenie field, Amadeus Basin, central Australia, and its subsequent development, in Case histories of oil and gas fields in Asia and the Far East (2nd series): United Nations Economic Committee for Asia and Far East, Mineral Resources Development Series, no. 29, p. 9-18.

Simpson, E. S. W., and Dingle, R. V., 1972, Offshore sedimentary basins on the southeastern continental margin of south Africa, in Reyre, D., ed., Bassins sédimentaires du littoral Africain, Part 1, Littoral Atlantique (New Delhi, 1964): Paris, Union Internationale des Sciences Géologiques, Association des Services Géologiques Africains, p. 63-67.

Smal1, J. Jr., 1963, Stratigraphy of southwest Ecuador and Ancon oil field studies : Dissertation Abstracts, v. 24, no. 3, p. 11391140 .

Smith, M. B., 1964, Map showing distribution and configuration of basement rocks in California: U.S. Geological Survey Oil and Gas Investigations Map, OM-125, scale 1:5,000,000.

Smith, R. J., 1953, Geology of the Los Teques-Cua region, Venezuela: Geological Society of America Bulletin, v. 64, no. 1, p. 41-64.

Smythe, D. K., and Kenolty, N., 1975, Tertiary sediments in the Sea of the Hebrides: Quarterly Journal of the Geological Society of London, v. 131, pt. 2, p. 227-233. 
Soeparjadi, R. A., and others, 1975, Exploration play concepts in Indonesia: World Petroleum Congress, 9th, Tokyo, 1975, Proceedings, v. 3, p. 51-64.

Sokolov, B. A., 1976, Geologic structure and petroleum potential of the arctic segment, in Sokolov, B. A., and others, Petroleum resources of seas and oceans: Moscow, Mir Publishers, Chapter 10, p. 215239.

Sokolov, B.A., and others, 1976, Petroleum resources of seas and oceans: Moscow, Mir Publishers, 267 p. [Translated from the Russian 1973 edition by $H$. C. Creighton].

Sonnenberg, F. P., 1963, Bolivia and the Andes, in Childs, O. E., and Beebe, B. W., eds., Backbone of the Americas: American Association of Petroleum Geologists Memoir 2, p. 36-46.

Soper, N. J., and others, 1976, Late Cretaceous-early Tertiary stratigraphy of the Kangerdlugssuaq area, east Greenland, and the age of opening of the northeast Atlantic: Quarterly Journal of the Geological Society of London, v. 132, pt. 1, p. 85-104.

Spizharsky, T. N., ed.-in-chief, 1964, Tectonic map of the USSR: Ministry of Geology, USSR, scale $1: 2,500,000,16$ sheets (3-sheet legend in English).

Sprigg, R. C., and others, 1969, $0 i 1$ and gas prospects of southern Taranaki Bight, New Zealand: American Association of Petroleum Geologists Bulletin, v. 53, no. 9, p. 1956-1977.

Stacey, R. A., 1975, Structure of the Queen Charlotte Basin, in Yorath, C. J., Parker, E. R., and Glass, D. J., eds., Canada's continental margins and offshore petroleum exploration: Canadian Society of Petroleum Geologists Memoir 4, p. 723-741.

Stach, L. W., 1947, Petroleum exploration and production in western Pacific during World War II: American Association of Petroleum Geologists Bulletin, v. 31, no. 8, p. 1384-1403.

Stevenson, H. R., 1962, Geophysical case history of the Alturitas Concession, State of Zulia, western Venezuela: Asociacion Venezolana de Geologia, Mineria y Petroleo Boletin Informativo, v. 5, no. 8, p. 231-249.

Stoeckinger, W. T., 1976a, Valencian Gulf offer deadline nears, Part 1: 0il and Gas Journal, v. 74, no. 13, p. 197-204.

1976b, Valencian Gulf offer deadline nears, Part 2: $0 i 1$ and Gas Journa1, v. 74 , no. 14 , p. 181-183. 
Stowell, C. E., 1974, 011 and gas development in the USSR: Tulsa, The Petroleum Publishing Company, $48 \mathrm{p}$.

Sundharovat, S., 1964, Report on the geology of oil, oil shale, and coal, in the Tertiary basins of northern Thailand with a hypothesis on the origin of the oil of probable non-marine origin: Thailand, Department of Mineral Resources, $37 \mathrm{p}$.

Sundvor, E., and Nysaether, E., 1975, Geological outline of the Norwegian continental margin between $60^{\circ}$ and $68^{\circ} \mathrm{N}$, in Yorath, C. J., Parker, E. R., and Glass, D. J., eds., Canada's continental margins and offshore petroleum exploration: Canadian Society of Petroleum Geologists Memoir 4, p. 267-281.

Suter, H. H., 1960, The general and economic geology of Trinidad, British West Indies: London, Her Majesty's Stationary Office, $145 \mathrm{p}$.

Taiwan Economics Department, 1972, Petroleum prospective areas and reserves of China: Houston, Texas, Esso Exploration Inc. [Translated by Chiang, D. M.]

Tamesis, E. V., and others, 1973, Late Tertiary geologic history of the continental shelf off northwestern Palawan, Philippines: Geological Society of Malaysia Bulletin 6, p. 165-176.

Tatham, R. H., 1975, Surface-wave dispersion applied to the detection of sedimentary basins: Geophysics, v. 40, no. 1, p. 40-55.

Temple, P. G., and Perry, L. J., 1962, Geology and oil occurrence, southeast Turkey: American Association of Petroleum Geologists Bulletin, v. 46, no. 9, p. 1596-1612.

Templeton, R. S. M., 1971, The geology of the continental margin between Dakar and Cape Palmas, in Delany, F. M., ed., The geology of the East Atlantic continental margin--4 Africa: Great Britain Institute Geological Sciences Report 70/16, p. 43-60.

Terman, M. J., and Woo, C. C., 1967, China and Mongolia, in Atlas of the Sino-Soviet Bloc to support detection of underground nuclear testing, Volume 2, Tectonics: U.S. Geological Survey, scale 1:5,000,000.

Terman, M. J., and others, 1974, Tectonic map of China and Mongolia: Geological Society of America, scale 1:5,000,000, 2 sheets.

Thein, M., 1973, A preliminary synthesis of the geological evolution of Burma with references to the tectonic development of southeast Asia: Geological Society of Malaysia Bulletin 6, p. 87-116.

Thomas, B. M., and Smith, D. N., 1974, A summary of the petroleum geology of the Carnarvon Basin: Australian Petroleum Exploration Journal, v. 14, pt. 1 , p. 66-70. 
1975, Australia's Carnarvon Basin has successful exploration background: $0 i 1$ and Gas Journal, v. 73, no. 18, p. 292-294.

Thomas, T. M., 1975, Search for hydrocarbons in shelf seas of northwest Europe: American Association of Petroleum Geologists Bulletin, v. 59, no. 4, p. 573-617.

Tooms, J. S., Summerhays, C. P., and McMaster, R. L., 1971, Marine geological studies on the northwest African margin Rabat-Dakar, in Delany, F. M., ed., The geology of the East Atlantic continental margin--4 Africa: Great Britain Institute Geological Sciences Report 70/16, p. 9-26.

Trofimuk, A. A., ed., 1971, 0il and gas prospective basins of the far eastern USSR: Moscow, Nedra, 184 p.

Trumbull, J., and others, 1958, An introduction to the geology and mineral resources of the continental shelves of the Americas: U.S. Geological Survey Bulletin 1067, 92 p.

Trumpy, D., 1943, Pre-Cretaceous of Colombia: Geological Society of America Bulletin, v. 54, no. 9, p. 1281-1304.

Tschopp, H. J., 1953, Oil explorations in the Oriente of Ecuador: American Association of Petroleum Geologists Bulletin, v. 37, no. 10 , p. 2303-2347.

Uchupi, E., Ballard, R. D., and Ellis, J. P., 1977, Continental slope and upper rise off western Nova Scotia and Georges Bank: American Association of Petroleum Geologists Bulletin, v. 61, no. 9, p. 1483-1492.

Uchupi, E., and others, 1976, Continental margin off western Africa-Senegal to Portugal: American Association of Petroleum Geologists Bulletin, v. 60 , no. 5, p. 809-878.

Think, F. M., 1965, Petroleum development in Mexico: American Association of Petroleum Geologists Bulletin, v. 49, no. 8, p. 1102-1111.

United Nations, 1962, $0 i 1$ and natural gas map of Asia and the Far East: United Nations Economic Committee for Asia and Far East, scale $1: 5,000,000$.

1971a, Geologic map of Asia and the Far East (revised): United Nations Economic Committee for Asia and Far East, scale 1:5,000,000. 
1971b, Symposium on investigations and resources of the Caribbean Sea and adjacent regions: United Nations Educational, Scientific, Cultural Organization, Paris, 545 p.

1972, International map of natural gas fields of Europe: United Nations Economic Commission for Europe, Committee on Gas, scale $1: 2,500,000$.

Urien, C. M., and Ewing, M., 1974, Recent sediments and environments southern Brazil, Uruguay, Buenos Aires, and Rio Negro continental shelf, in Burk, C. A., and Drake, C. L., eds., The geology of continental margins: New York, Springer-Verlag, p. 157-177.

Urien, C. M., and Zambrano, J. J., 1973, The geology of the basins of the Argentine continental margin and Malvinas Plateau, in Nairn, A. E. M., and Stehli, F. G., eds., The ocean basins and margins, Volume 1, The South Atlantic: New York, Plenum Press, p. 135-166.

USSR Ministry of Geology, 1961, Tectonic map of USSR: USSR, Ministry of Geology, scale $1: 10,000,000$.

Van Andel, T. H., 1967, The Orinoco Delta: Journal of Sedimentary Petrology, v. 37, no. 2, p. 297-310.

Vedder, J. G., and others, 1974, Preliminary report on the geology of the continental borderland of southern California: U.S. Geological Survey Miscellaneous Field Studies Map, MF-624.

Vinson, G. L., 1962, Upper Cretaceous and Tertiary stratigraphy of Guatemala: American Association of Petroleum Geologists Bulletin, v. 46, no. 4 , p. 425-456.

Vinson, G. L., and Brineman, J. H., 1963, Nuclear Central America, Hub of Antillean transverse belt, in Childs, O. E., and Beebe, B. W., eds., Backbone of the Americas: American Association of Petroleum Geologists Memoir 2, p. 101-112.

Vysotskiy, I. V., and Kucheruk, E. V., eds., 1974, Deposits of fossil fuels; The major gas and gas condensate deposits of the world, Volume 5: Boston, G. K. Hall and Co., 111 p.

Vysotskiy, I. V., Selitskiy, A. G., and Tursina, V. V., 1969, The oil and gas basins of Africa: Izvestiia Vysshikh Uchebnykh Zavedenii, Geologiia Razvedka, no. 5, p. 133-143 (Trans. Vitaliano, D. B., August 1973).

Wageman, J. M., Hilde, T. W. C., and Emery, K. O., 1970, Structural framework of East China Sea and Yellow Sea: American Association of Petroleum Geologists Bulletin, v. 54, no. 9, p. 1611-1643.

Walper, J. L., 1960, Geology of Cuban-Purhula area, Alta Verapaz, Guatemala: American Association of Petroleum Geologists Bulletin, v. 44, no. 8, p. 1273-1315. 
Walters, R., and Linton, R. E., 1973, The sedimentary basin of coastal Kenya, in Blant, G., ed., Bassin sédimentaire du littoral Africain, Part 2, Littoral austral et oriental (Montreal, 1972): Paris, Union Internationale des Sciences Géologiques Association des Services Géologiques Africains, p. 133-158.

Wang, C. S., 1974, The South China Basin as a relict ocean: Bulletin Geological Survey Taiwan, no. 24, p. 133-137.

Wang, K. P., 1977, Mineral resources and basic industries in the People's Republic of China: Boulder, Colorado, Westview Press, 211 p.

Watson, J. M., and Swanson, C. A., 1975, North Sea--major petroleum province: American Association of Petroleum Geologists Bulletin, v. 59, no. 7, p. 1098-1112.

Weber, H. S., Wiesemann, G., and Wittekindt, H., eds., 1974, Mapa geologico general de la Republica de El Salvador: Hanover, Bundesanstalt Bodenforschung, scale 1:500,000, 1 sheet.

Weber, K. J., and Daukoru, E., 1975, Petroleum geology of the Niger Delta: World Petroleum Congress, 9th, Tokyo, 1975, Proceedings, v. 2, p. 209-221.

Weeks, L. A., and others, 1971, Structural relations among Lesser Antilles, Venezuela and Trinidad-Tobago: American Association of Petroleum Geologists Bulletin, v. 55, no. 10, p. 1741-1752.

Weeks, L. G., 1966, Assessment of the world's offshore petroleum resources and exploration review: Institute on Exploration and Economics of the Petroleum Industry, v. 4, p. 115-148.

Wheeler, C. B., 1963, Oligocene and lower Miocene stratigraphy of western and northeastern Falcon Basin, Venezuela: American Association of Petroleum Geologists Bulletin, v. 47, no. 1, p. 3568 .

Whitbread, D. R., 1975, Geology and petroleum possibilities west of the United Kingdom, in Woodland, A. W., ed., Petroleum and the continental shelf of northwest Europe, Volume 1: New York, John Wiley and Sons, p. 45-59.

White, R. W., 1972, Stratigraphy and structure of basins on the coast of Liberia: Liberian Geological Survey Special Paper no. 3, 14 p.

Williams, H., McBirney, A. R., and Dengs, G., 1964, Geologic reconnaissance of southeastern Guatemala: University of California Publications in Geological Sciences, v. 50, p. 1-56.

Williams, J. J., Conner, D. C., and Peterson, K. E., 1975, Piper oil field, North Sea fault block structure with upper Jurassic beach/bar reservoir sands: American Association of Petroleum Geologists Bulletin, v. 59, no. 9, p. 1585-1601. 
Williams, L. W., Forman, D. J., and Hawkins, P. J., 1975, Appraisal of the Sahul Shelf needed: $0 i 1$ and Gas Journal, v. 73, no. 21, p. 128-130.

Williams, R. N., 1963, Cordillera of Chile, in Childs, 0. E., and Beebe, B. W., eds., Backbone of the Americas: American Association of Petroleum Geologists Memoir 2, p. 29-35.

Wilson, J. J., 1963, Cretaceous stratigraphy of central Andes of Peru: American Association of Petroleum Geologists Bulletin, v. 47, no. 1, p. 1-34.

Winston, G. 0., 1971, Regional structure, stratigraphy, and oil possibilities of the South Florida Basin: Gulf Coast Association of Geological Societies, Transactions, v. 21, p. 15-29.

Winter, H. De La R., 1973, Geology of the Algoa Basin, South Africa, in Reyre, D., ed., Bassins sédimentaires du littoral Africain, Part $\overline{1}$, Littoral Atlantique (New Delhi, 1964): Paris, Union Internationale des Sciences Géologiques Association des Services Géologiques Africains, p. 17-48.

Woodring, W. P., 1954, Caribbean land and sea through the ages: Geological Society of America Bulletin, v. 65, no. 8, p. 719-732.

Wopfner, H., 1967, Case history of the Gidgealpa gas field, south Australia, in Case histories of oil and gas fields in Asia and the Far East (2nd series): United Nations Economic Committee for Asia and Far East, Mineral Resources Development Series, no. 29, p. 3452 .

1970, Early Cambrian paleogeography, Frome Embayment, south Australia: American Association of Petroleum Geologists Bulletin, v. 54, no. 12 , p. 2395-2409.

Yorath, C. J., Parker, E. R., and Glass, D. J., eds., 1975, Canada's continental margins and offshore petroleum exploration: Canadian Society of Petroleum Geologists Memoir 4, 898 p.

Zambrano, E., and others, 1970, Paleogeographic and petroleum synthesis, western Venezuela (1): Revue de 1 'Institut Français du Pétrole, v. 25, no. 12, p. 1449-1492.,

Zambrano, J. J., and Urien, C. M., 1970, Geological outline of the basins in southern Argentina and their continuation off the Atlantic shore: Journal of Geophysical Research, v. 75, no. 8, p. 13631396.

Ziegler, P. A., 1975, Geologic evolution of North Sea and its tectonic framework: American Association of Petroleum Geologists Bulletin, v. 59, no. 7, p. 1073-1097.

Zverev, S. M., and Tulina, Y. V., 1973, Peculiarities in the deep structure of the Sakhalin-Hokkaido-Primorye Zone: Tectonophysics, v. 20, no. $1-4$, p. 115-127. 
GEOGRAPHICAL INDEX

General References

Bakirov, A. A., Varentsov, M. I., and Bakirov E. A., 1971, $0 i 1$ and gas provinces and districts of the countries of the world: Moscow, Nedra, 542 p.

Childs, 0. E., and Beebe, B. W., eds., 1963, Backbone of the Americas: American Association of Petroleum Geologists Memoir 2, 320 p.

Halbouty, M. T., and others, 1970, World's giant oil and gas fields, geologic factors affecting their formation, and basin classification, Pt. 1, Giant oil and gas fields, in Halbouty, M. T., ed., Geology of giant petroleum fields: American Association of Petroleum Geoloigists Memoir 14, p. 502528.

Halbouty, M. T., Maher, J. C., and Lian H. M., eds., 1976, CircumPacific Energy and Mineral Resources: Circum-Pacific Energy and Mineral Resources Conference, Honolulu, Hawaii, 1974, Proceedings American Association of Petroleum Geologists Memoir 25, 608 p.

Landes, K. K., 1959, Petroleum geology (2nd ed.): New York, John Wiley and Sons, Inc., $443 \mathrm{p}$.

McDowel1, A. N., 1975, What are the problems in estimating the oil potential of a basin?: $0 i 1$ and Gas Journal, v. 73, no. 23, p. 8590.

Moody, G. B., ed., 1961 Petroleum exploration handbook: New York, McGraw-Hill, 25 chapters.

Sokolov, B. A., and others, 1976, Petroleum resources of seas and oceans: Moscow, Mir Publishers, 267 p. (Translated from the Russian 1973 edition by H. C. Creighton).

Trumbul1, J., and others, 1958, An introduction to the geology and mineral resources of the continental shelves of the Americas: U.S. Geological Survey Bulletin 1067, 92 p.

Vysotskiy, I. V., and Kucheruk, E. V., eds., 1974, Deposits of fossil fuels; The major gas and gas condensate deposits of the world, Volume 5: Boston, G. K. Hall and Company, 111 p.

Weeks, L. G., 1966, Assessment of the world's offshore petroleum resources and exploration review: Institute on exploration and economics of the petroleum industry, v. 4, p. 115-148. 


\section{Africa}

\section{Africa--general}

Beck, R. H., and Lehner, P., 1974, Oceans, new frontier in exploration: American Association of Petroleum Geologists Bulletin, v. 58, no. 3, p. 376-395.

Choubert, G., general coordinator, 1968a, Carte tectonique internationale de 1'Afrique: Association of African Geological Surveys and United Nations Educational, Scientific, Cultural Organization, scale 1:5,000,000, 9 sheets.

general coordinator, 1968b, International tectonic map of Africa, explanatory note: Association of African Geological Surveys and United Nations Educational, Scientific, Cultural Organization.

Franchetean, J., and LePichon, X., 1972, Marginal fracture zones as structural framework of margins in south Atlantic Ocean: American Association of Petroleum Geologists Bulletin, v. 56, no. 6, p. 991-1007.

Moody, J. D., 1964, Petroleum development in Africa in 1963: American Association of Petroleum Geologists Bulletin, v. 48, no. 10, p. 16221665.

Vysoskiy, I. V., Selitskiy, A. G., and Tursina, V. V., 1969, The oil and gas basins of Africa: Izvestila Vysshikh Uchebnykh Zavedenii, Geologiia Razvedka, no. 5, p. 133-143 (trans. Vitaliano, D. B., August 1973).

\section{Eastern Africa}

Delteil, J. R., and others, 1978, Continental margins of the Southwestern Indian Ocean: Offshore Techonology Conference, 10th Annual, Houston, Texas, 1978, Proceedings, OTC 3264, p. 1835-1841.

Kent, P. E., 1974, Continental margin of east Africa--A region of vertical movement, in Burk, C. A., and Drake, C. L., eds., The geology of continental margins: New York, Springer-Verlag, p. 313-320.

\section{Northern Africa}

Biju-Duval, B., and others, 1974, Geology of the Mediterranean Sea basins, in Burk, C. A., and Drake, C. L., eds., The geology of continental margins: New York, Springer-Verlag, p. 695-721.

Kent, P. E., 1969, The geological framework of petroleum exploration in Europe and north Africa and the implications of continental drift hypothesis, in Hepple, P., ed., The exploration for petroleum in Europe and north Africa: London, Institute of Petroleum, p. 3-17. 


\section{Northwestern Africa}

Templeton, R.'S. M., 1971, The geology of the continental margin between Dakar and Cape Palmas, in Delany, F. M., ed., The geology of the east Atlantic continental margin--4 Africa: Great Britain Institute Geological Sciences Report 70/16, p. 43-60.

Tooms, J. S., Summerhays, C. P., and McMaster, R. L., 1971, Marine geological studies on the northwest African margin Rabat-Dakar, in Delany, F. M., ed., The geology of the east Atlantic continental margin--4 Africa: Great Britain Institute Geological Sciences Report 70/16, p. 9-26.

Uchupi, E., and others, 1976, Continental margin off western Africa-Senegal to Portugal: American Association of Petroleum Geologists Bulletin, v. 60 , no. 5, p. 809-878.

\section{Southern Africa}

Dingle, R. V., and Scrutton, R. A., 1974, Continental breakup and the development of post-Paleozoic sedimentary basins around southern Africa: Geological Society of America Bulletin, v. 85, no. 9, p. 1467-1474.

Simpson, E. S. W., and Dingle, R. V., 1972, offshore sedimentary basins on the southeastern continental margin of south Africa, in Reyre, D., ed., Bassins sédimentaires du littoral Africain, Part 1, Littoral Atlantique (New Delhi, 1964): Paris, Union Internationale des Sciences Géologiques, Association des Services Gélogiques Africains, p. 63-67.

Winter, H. De La R., 1973, Geology of the Algoa Basin, south Africa, in Reyre, D., ed., Bassins sedimentaires du littoral Africain, Part $\bar{I}$, Littoral Atlantique (New Delhi, 1964): Paris, Union Internationale des Sciences Géologiques, Association des Services Géologiques Africains, p. 17-48.

\section{Western Africa}

Delteil, J. R., and others, 1974, Continental margins in the northern part of the Gulf of Guinea, in Burk, C. A., and Drake, C. L., eds., The geology of continental margins: New York, Springer-Verlag, p. 297-311.

Dillon, W. P., and Sougy, J. M. A., 1974, Geology of west Africa and Canary and Cape Verde Islands, in Nairn, A. E. M., and Stehli, F. G., eds., Ocean basins and margins, Volume 2, North Atlantic: New York, Plenum Press, p. 315-390. 
Emery, K. 0., and others, 1975, Continental margin off western Africa-Angola to Sierra Leone: American Association of Petroleum Geologists Bulletin, v. 59, no. 12, p. 2209-2265.

Leyden, R., Bryan, G., and Ewing, M., 1972, Geophysical reconnaissance on African shelf; 2. Margin sediment from Gulf of Guinea to Walvis Ridge: American Association of Petroleum Geologists Bulletin, v. 56 , no. 4, p. 682-693.

McMaster, R. I., DeBoer, J., and Ashraf, A., 1970, Magnetic and seismic reflection studies on continental shelf off Portuguese Guinea, Guinea and Sierra Leone, west Africa: American Association of Petroleum Geologists Bulletin, v. 54, no. 1, p. 158-168.

Renard, V., and Mascle, J., 1974, Eastern Atlantic continental margins-various structural and morphological types, in Burk, C. A., and Drake, C. L., eds., The geology of continental margins: New York, Springer-Verlag, p. 285-291.

Reyre, D., 1964, Particularités géologiques des bassins côtiers de 1 'ouest Africain, in Reyre, D., ed., Bassins sédimentaires du 1ittoral Africain, Part 1, Littoral Atlantique (New Delhi, 1964): Paris, Union Internationale des Sciences Geologiques, Association des Services Géologiques Africains, p. 275-284.

Seibold, E., and Hinz, K., 1974, Continental slope construction and destruction, west Africa, in Burk, C. A., and Drake, C. L., eds., The geology of continental margins: New York, Springer-Verlag, p. 179-196.

\section{Cameroon}

Reyre, D., 1966, Histoire géologique du bassin de Douala (Cameroun), in Reyre, D., ed., Bassins sédimentaires du littoral Africain, Part $\overline{1}$, Littoral Atlantique (New Delhi, 1964): Paris, Union Internationale des Sciences Gélogiques, Association des Services Géologiques Africains, p. 143-161.

\section{Egypt}

Ross, D. A., and Uchupi, E., 1977, Structure and sedimentary history of southeastern Mediterranean Sea--Nile Cone area: American Association of Petroleum Geologists Bulletin, v. 61, no. 6, p. 872-902.

\section{Ghana}

Arens, G., and others, 1971, The continental margin off the Ivory Coast and Ghana, in Delany, F. M., ed., The geology of the east Atlantic continental margin- 4 Africa: Great Britain Institute of Geological Sciences Report 70/16, p. 61-78. 


\section{Ivory Coast}

Arens, G., and others, 1971, The continental margin off the Ivory Coast and Ghana, in Delany, F. M., ed., The geology of the east Atlantic continental margin--4 Africa: Great Britain Institute of Geological Sciences Report 70/16, p. 61-78.

DeSpengler, A., and Delteil, J.-R., 1966, Le bassin secondaire-tertiaire de Cote d'Ivoire, in Reyre, D., ed., Bassins sedimentaires du littoral Africain, Part 1, Littoral Atlantique (New Delhi, 1964): Paris, Union Internationale des Sciences Géologiques, Association des Services Géologiques Africains, p. 99-113.

$\underline{\text { Kenya }}$

Walters, R., and Linton, R. E., 1973, The sedimentary basin of coastal Kenya, in Blant, G., ed., Bassin sédimentaire du littoral Africain, Part 2, Littoral Austral et Oriental (Montreal, 1972): Paris, Union Internationale des Sciences Géologiques, Association des Services Géologiques Africains, p. 133-158.

\section{Liberia}

Schlee, J., and others, 1974, Shallow structure and stratigraphy of Liberian continental margin: American Association of Petroleum Geologists Bulletin, v. 58, no. 4, p. 708-728.

White, R. W., 1972, Stratigraphy and structure of basins on the coast of Liberia: Liberian Geological Survey Special Paper no. 3, 14 p.

\section{Libya}

Conant, L. C., and Goudarzi, G. H., 1967, Stratigraphic and tectonic framework of Libya: American Association of Petroleum Geologists Bulletin, v. 51, no. 5, p. 719-730.

\section{Morocco}

Dillon, W. P., 1974, Structural development of the southern Moroccan continental shelf: Marine Geology, v. 16, no. 3, p. 121-143.

Robb, J. P., 1971, Structure of continental margins between Cape Rhir and Cape Sim, Morocco northwest Africa: American Association of Petroleum Geologists Bulletin, v. 55, no. 5, p. 643-651.

\section{Nigeria}

Adeleye, D. R., 1975, Nigerian late Cretaceous stratigraphy and paleogeography: American Association of Petroleum Geologists Bulletin, v. 59, no. 12, p. 2302-2313.

Avbovbo, A. A., 1978a, Tertiary Iithostratigraphy of Niger Delta: American Association of Petroleum Geologists Bulletin, v. 62, No. 2, p. 295-306. 
1978b, Geothermal gradients in southern Nigeria Basin: Bulletin of Canadian Petroleum Geology, v. 26, no. 2, p. 268-274.

Hospers, J., 1971, The geology of the Niger Delta area, in Delany, F. M., ed., The geology of the east Atlantic continental margin--4 Africa: Great Britain Institute of Geological Sciences Report 70/16, p. 121-142.

Weber, K. J., and Daukoru, E., 1975, Petroleum geology of the Niger Delta: World Petroleum Congress, 9th, Tokyo, 1975, Proceedings, v. 2, p. 209-221.

\section{Senegal}

Aymé, J. M., 1965, The Senegal salt basin, in Salt basins around Africa: London, Institute of Petroleum, p. 83- $\overline{90}$.

\section{Sierra Leone}

McMaster, R. I., Christofferson, E., and Ashraf, A., 1975, Structural framework of continental shelf and slope off southwestern Sierra Leone, west Africa: American Association of Petroleum Geologists Bulletin, v. 59, no. 11, p. 2161-2171.

\section{Somalia}

Beltrandi, M. D., and Pyre, A., 1973, Geological evolution of southwest Somalia, in Blant, G., ed., Bassins sédimentaires du littoral Africain, Part 2, Littoral Austral et Oriental (Montreal, 1972): Paris, Union Internationale des Sciences Géologiques, Association des Services Geologiques Africains, p. 159-178.

Delteil, J. R., and others, 1978, Continental margins of the Southwestern Indian Ocean: Offshore Technology Conference 10th Annual, Houston, Texas, 1978, Proceedings, OTC 3264, p. 1835-1841

\section{Spanish Sahara}

Querol, R., 1966, Regional geology of the Spanish Sahara, in Reyre, D., ed., Bassins sédimentaires du littoral Africain, Part $\overline{1}$, Littoral Atlantique (New Delhi, 1964): Paris, Union Internationale des Sciences Géologiques, Association des Services Géologiques Africains, p. 27-38.

\section{Tanzania}

Kent, P. E., and Perry, J. T. O'B., 1973, The development of the Indian Ocean margin in Tanzania, in Blant, G., ed., Bassins sédimentaires du littoral Africain, Part 2, Littoral Austral et Oriental (Montreal, 1972): Paris, Union Internationale des Sciences Géologiques, Association Services Géologiques Africains, p. 113-131. 


\section{Asia}

\section{Asia--general}

Caldwell, R. D., 1975, Petroleum developments in Far East in 1974: American Association of Petroleum Geologists Bulletin, v. 59, no. 10, p. 1977-2010.

Gaffney, P. D., Moyes, C.P., and Aling, B., 1976, Economic appraisal of the potential petroleum resources of the Asian Pacific region: Australian Petroleum Exploration Association Journal, v. 16, no. 2, p. 56-62.

Geodekyan, A. A., and others, 1975, Geological-geochemical evaluation of possible oil and gas content of the Bering Sea, the Seas of Okhotsk and Japan, the northwestern Pacific and the Arctic Ocean: World Petroleum Congress, 9th, Tokyo, 1975, Proceedings, v. 2, p. 337346.

Gringorenko, Jr. N., and others, 1975, The oil and gas producing basins of the shelves of northeastern Asia, in Yorath, C. J., Parker, E. R., and Glass, D. J., eds., Canada's continental margins and offshore petroleum exploration: Canadian Society of Petroleum Geologists Memoir 4, p. 663-668.

Meyerhoff, A. A., 1973, Origin of Arctic and north Atlantic Oceans, in Pitcher, M. G., ed., Arctic geology: American Association of Petroleum Geologists Memoir 19, p. 562-582.

Murphy, R. W., 1975, Tertiary basins of southeast Asia: Southeast Asia Petroleum Exploration Society, Proceedings, v. 2, p. 1-36.

Paul, D. D., and Lian, H. M., 1975, Offshore Tertiary basins of southeast Asia, Bay of Bengal to South China Sea: World Petroleum Congress, 9th, Tokyo, 1975, Proceedings, v. 3, p. 107-121.

Ray, K. K., and Acharyya, S. K., 1976, Concealed Mesozoic-Cenozoic Alpine Himalayan geosyncline and its petroleum possibilities: American Association of Petroleum Geologists Bulletin, v. 60, no. 5, p. 794-808.

Sander, N. J., Humphrey, W. E., and Mason, J. F., 1975, Tectonic framework of southeast Asia and Australia--Its significance in the occurrence of petroleum: World Petroleum Congress, 9th, Tokyo, 1975, Proceedings, v. 3, p. 83-105.

Terman, M. J., 1975, Work maps of sedimentary basins of Asia and the USRR: Unpublished work maps, scale 1:5,000,000. 
United Nations, 1962, Oil and natural gas map of Asia and the Far East: United Nations Economic Committee for Asia and Far East, scale $1: 5,000,000$.

1971, Geologic map of Asia and the Far East (revised): United Nations Economic Committee for Asia and Far East, scale 1:5,000,000.

\section{Burma}

Burma Ministry of Mine Geology Department, 1968, Geological map of Burma: Burma Ministry of Mine Geology Department, scale 1:1,000,000.

Brown, J. C. and Dey, A. K., 1975, The Mineral and Nuclear Fuels of the Indian Subcontinent and Burma: Delhi, Oxford University Press, p. 237-411.

Thein, M., 1973, A preliminary synthesis of the geological evolution of Burma with references to the tectonic development of southeast Asia: Geological Society of Malaysia Bulletin 6, p. 87-116.

China

Chang, S. S. L., 1968, Regional stratigraphic study of neogene formations in Chiayi-Hsinying area, west-central Taiwan, China: American Association of Petroleum Geologists Bulletin, v. 52, no. 12, p. 2438-2465.

Ho, C. S., 1971, The Tertiary basins of Taiwan: Bulletin of the Geological Survey of Taiwan, no. 23, p. 1-52.

Li, W. Y. L., 1970, Geologic map of the Republic of China: Chinese Petroleum Corporation, scale 1:4,000,000.

1971, An outline of the petroleum geology on the mainland of China: Petroleum Geology of Taiwan, no. 9, p. 205-225 (English trans. Chaing, D. M., Esso Exploration, Houston, Tex.).

Meng, C. Y., and Chou, J. T., 1975, The petroliferous Taiwan basins in the framework of the western Pacific Ocean: Chinese Petroleum Corporation, $12 \mathrm{p}$.

Meyerhoff, A. A., 1970, Developments in mainland China 1949-1968: American Association of Petroleum Geologists Bulletin, v. 54, no. 8, p. 1567-1580.

1973, Geopolitical implications of Russian and Chinese petroleum, in Cameron, V. S., ed., Exploration and economics of the petroleum industry, Volume II: New York, Matthew Bender and Co., p. 79-127.

Meyerhoff, A. A., and Willums, J. 0., 1976, Petroleum geology and industry of the People's Republic of China: United Nations ESCAP, CCOP Technical Bulletin, v. 10, 212 p.

Offshore, 1974, Subsea oil off Chinese coast fires up geopolitical arena: Offshore, v. 34 , no. 7 , p. 184-185. 
Powell, C. McA., and Conaghan, P. J., 1975, Tectonic models of the Tibetan plateau: Geology, v. 3, no. 12, p. 727-731.

Taiwan Economics Department, 1972, Petroleum prospective areas and reserves of China: Houston, Texas, Esso Exploration Inc. [translated by Chiang, D. M.]

Terman, M. J., and Woo, C. C., 1967, China and Mongolia, in Atlas of the Sino-Soviet Bloc to support detection of underground nuclear testing, Volume 2, Tectonics: U.S. Geological Survey, scale 1:5,000,000.

Terman, M. J. and others, 1974, Tectonic map of China and Mongolia: Geological Society of America, scale 1:5,000,000, 2 sheets.

Wageman, J. M., Hilde, T. W. C., and Emery, K. 0., 1970, Structural framework of East China Sea and Yellow Sea: American Association of Petroleum Geologists Bulletin, v. 54, no. 9, p. 1611-1643.

Wang, C. S. 1974, The South China Basin as a relict ocean: Bulletin of the Geological Survey of Taiwan, no. 24, p. 133-137.

Wang, K. P., 1977, Mineral resources and basic industries in the People's Republic of China: Westview Press, Boulder, Colorado, 211 p.

India

Bhandari, L. L., Fuloria, R. C., and Sastri, V. V., 1973, Stratigraphy of Assam Valley, India: American Association of Petroleum Geologists Bulletin, v. 57, no. 4, p. 642-654.

Brown, J. C. and Dey, A. K., 1975, The Mineral and Nuclear Fuels of Indian Subcontinent and Burma: Delhi, Oxford University Press, p. 237-411.

Chowdhary, L. R., 1975, Reversal of basement-block motions in Cambay Basin, India, and its importance in petroleum exploration: American Association of Petroleum Geologists Bulletin, v. 59, no. 1, p. 8596.

Closs, H., Narain, H., and Garde, S. C., 1974, Continental margins of India, in Burk, C. A., and Drake, C. L., eds., The geology of continental margins: New York, Springer-Verlag, p. 629-639.

Curray, J. R., and Moore, D. G., 1971, Growth of the Bengal deep-sea fan and denudation in the Himalayas: Geological Society of America Bulletin, v. 82, no. 3, p. 563-572. 
1974, Sedimentary and tectonic processes in the Bengal deep-sea fan and geosyncline, in Burk, C. A., and Drake, C. L., eds., The geology of continental margins: New York, Springer-Verlag, p. 617628.

India, Geological Survey of, 1963, Tectonic map of India: Geological Survey of India, scale $1: 2,000,000,4$ sheets.

Kailasam, L. N., 1976, Geophysical studies of the major sedimentary basins of the Indian craton, their deep structural features and evolution: Unpublished, $20 \mathrm{p}$.

Offshore, 1975, Indian Ocean: Offshore, v. 35, no. 4, p. 124-126.

Raju, A. T. R., 1968, Geological evolution of Assam and Cambay Tertiary basins of India: American Association of Petroleum Geologists Bulletin, v. 52, no. 12, p. 2422-2437.

Ramakotaiah, G., and Avasthi, D. N., 1974, The status of geophysical knowledge in the east coast and eastern basins of India: Australian Petroleum Exploration Association Journal, v. 14, pt. 1, p. 42-44.

Rao, V. R., 1973, Pre-Cambrian basement depths in some sedimentary basins of India: Geophysical Research Bulletin, v. 11, no. 4, p. 267-272.

Sastri, V. V., and others, 1972, Poorly explored sedimentary basins of India, in Proceedings of the Fourth Symposium on the Development of Petrcleum Resources of Asia and the Far East: United Nations Economic Committee for Asia and Far East, Mineral Resources Development Series 41, v. 1, p. 381-406.

1973, Stratigraphy and tectonics of sedimentary basins on east coast of peninsular India: American Association of Petroleum Geologists Bulletin, v. 57, no. 4, p. 655-678.

1974, Evolution of the Mesozoic sedimentary basins on the east coast of India: Australian Petroleum Exploration Association Journal, v. 14, pt. 1, p. 29-41.

Schott, W., Branson, J. C., and Turpie, A., 1975, Petroleum potential of the deep-water regions of the Indian Ocean: World Petroleum Congress, 9th, Tokyo, 1975, Proceedings, v. 2, p. 319-335.

\section{Indochina}

Paul, D. D., and Lian, H. M., 1975, Offshore Tertiary basins of southeast Asia, Bay of Bengal to South China Sea: World Petroleum Congress, 9th Tokyo, 1975, Proceedings v. 3, p. 107-121.

Ponlahan, P., 1973, Oil-gas basins of Indochina: Thailand, Department of Mineral Resources, Mineral Fuels Division, scale 1:5,000,000. 


\section{Indonesia}

Ben-Avraham, Z., 1973, Sonobuoy refraction measurements in the Java Sea: United Nations Economic Committee for Asia and Far East, Committee for Coordination of Joint Prospecting for Mineral Resources in Asian Offshore Areas, Technical Bulletin 7, p. 39-53.

Ben-Avraham, Z., and Emery, K. 0., 1973, Structural framework of Sunda Shelf: American Association of Petroleum Geologists Bulletin, v. 57, no. 12, p. 2323-2366.

Gribi, E. A., Jr., 1974, Petroleum geology of the Moluccas, eastern Indonesia: Southeast Asia Petroleum Exploration Society, Proceedings, v. 1 , p. 25-30.

Hamilton, W., 1973, Tectonics of the Indonesia region: Geological Society of Malaysia Bulletin 6, p. 3-10.

1974, Map of sedimentary basins of the Indonesia region: U.S. Geological Survey Map I-875B, scale 1:5,000,000.

Pulunggono, A., 1974, Recent knowledge on hydrocarbon potentials in the sedimentary basins of Indonesia: Handout of paper presented at Circum-Pacific Energy and Mineral Resources Conferences, 26 p.

Soeparjadi, R. A., and others, 1975, Exploration play concepts in Indonesia: World Petroleum Congress, 9th, Tokyo, 1975, Proceedings, v. 3 , p. 51-64.

$\underline{\operatorname{Iran}}$

Iran, Geological Survey of, 1973, Tectonic map of Iran: Geological Survey of Iran, scale $1: 2,500,000$.

Israel

Ginzberg, A., and others, 1975, Geology of Mediterranean shelf of Israel: American Association of Petroleum Geologists Bulletin, v. 59, no. 11 , p. $2142-2160$.

Japan

Burk, C. A., 1975, Sea of Okhotsk--thirteenth cruise of the Dmitry Mendeleev: Geology, v. 3, no. 3, p. 141-144.

Foster, H. L., 1962, Sedimentary basins and petroleum exploration in Japan: American Association of Petroleum Geologists Bulletin, v. 46, no. 2, p. 267. 
Hilde, T. W. C., and Wageman, J. M., 1973, Structure and origin of the Japan Sea, in Coleman, P. J., ed., The western Pacific--island arcs, marginal seas, geochemistry: New York, Crane, Russak and Co., Inc., p. 415-434.

International Petroleum Consultants, 1975, Japan and South Korea, synopsis first half, 1975 : International Petroleum Consultants, scale

Japan, Geological Survey of, 1964, Geological map of Japan: Geological Survey of Japan, scale 1:2,000,000.

Japan, Government of, 1965, Case histories of gas fields recently developed in Niigata District, Japan, in Case histories of oil and gas fields in Asia and the Far East (2nd series): United Nations Economic Committee for Asia and Far East, Mineral Resources Development series, no. 29, p. 64-80.

Japanese Delegation, 197la, Case histories of oil fields along the western margin of Lake Hachirogata, northwestern Honshu, Japan, in Case histories of oil and gas fields in Asia and the Far East (3rd series): United Nations Economic Committee for Asia and Far East, Mineral Resources Development Series, no. 37, p. 58-61.

1971b, Case history of the Hirakida gas field, northwestern Honshu, Japan, in Case histories of oil and gas fields in Asia and the Far East (3rd series): United Nations Economic Committee for Asia and Far East, Mineral Resources Development Series, no. 37, p 68-71.

1971c, Case history of the Minami-aga oil field, northwestern Honshu, Japan, in Case histories of oil and gas fields in Asia and the Far East (3rd series): United Nations Economic Committee for Asia and Far East, Mineral Resources Development Series, no. 37, p. 72-76.

1971d, Case history of the Nakajo-Shintainai gas field, northwestern Honshu, Japan, in Case histories of oil and gas fields in Asia and the Far East (3rd series): United Nations Economic Committee for Asia and Far East, Mineral Resources Development Series, no. 37, p. 62-64.

1971e, Case history of the Yoshii gas field, northwestern Honshu, Japan, in Case histories of oil and gas fields of Asia and the Far East (3rd series): United Nations Economic Committee for Asia and Far East, Mineral Resources Development Series, no. 37, p. 65-67.

17 Available only from Petroconsultants, SA, 2 Rue Vallin - 1211 Geneva 11, Switzerland. 
Kobayashi, K., and Toda, M., 1965, Wakimoto offshore structure discovered by submarine topographic survey in the Japan Sea, in Case histories of oil and gas fields in Asia and the Far East (2nd series): United Nations Economic Committee for Asia and Far East, Mineral Resources Development Series, no. 29, p. 81-85.

Ludwig, W. J., Murauchi, S., and Houtz, R. E., 1975, Sediments and structure of the Japan Sea: Geological Society of America Bulletin, v. 86 , no. 5, p. 651-664.

Stach, L. W., 1947, Petroleum exploration and production in western Pacific during World War II: American Association of Petroleum Geologists Bulletin, v. 31, no. 8, p. 1384-1403.

Zverev, S. M., and Tulina, Y. V., 1973, Peculiarities in the deep structure of the Sakhalin-Hokkaido-Primorye Zone: Tectonophysics, v. 20, no. 1-4, p. 115-127.

$\underline{\text { Korea }}$

Korea, Geological Survey of, 1972, Isotope ages and geological map of Korea: Geological Survey of Korea, scale 1:2,000,000.

International Petroleum Consultants, 1975, Japan and south Korea, synopsis first half 1975: International Petroleum Consultancs, scale $1: 2,000,000.1$

Reedman, A. J., and Um, S. H., 1975, The geology of Korea: Geological and Mineral Institute of Korea, $139 \mathrm{p}$.

\section{Middle East}

Fohs, F. J., 1947, Oil-reserve provinces of Middle East and southern Soviet Russia: American Association of Petroleum Geologists Bulletin, v. 31 , no. 8 , p. 1372-1383.

Kamen-Kaye, M., 1970, Geology and productivity of Persian Gulf synclinorium: American Association of Petroleum Geologists Bulletin, v. 54, no. 12, p. 2371-2394.

Kent, P. E., and Warman, H. R., 1972, An environmental review of the world's richest oil-bearing region--the Middle East: International Geological Congress, 24th, Montreal, 1972, Proceedings, sec. 5, p. 142-152.

McDowell, A. M., 1975, What are the problems in estimating the oil potential of a basin?: 0il and Gas Journal, v. 73, no. 23, p. 8590.

Vysotskiy, I. V., and Kucheruk, E. V., eds., 1974, Deposits of fossil fuels; The major gas and gas condensate deposits of the world, Volume 5: Boston, G. K. Hall and Co., Ill p.

\section{If Available only from Petroconsultants, SA, 2 Rue Vallin - 1211}

Geneva 11, Switzerland. 
Pacific Ocean

Gaffney, P. D., Moyes, C. P., and Aling, B., 1976, Economic appraisal of the potential petroleum resources of the Asian Pacific region: Australian Petroleum Exploration Association Journal, v. 16, no. 2, p. 56-62.

Karig, D. E., 1973, Comparison of island arc-marginal basin complexes in the northwest and southwest Pacific, in Coleman, P. J., ed., The western Pacific--island arcs, marginal seas, geochemistry: New York, Crane, Russak and Co., Inc., p. 355-364.

Khain, V. E., and Seslavinsky, K. B., 1973, Some basic problems of structure and tectonic history of the northwestern segment of the Pacific mobile belt, in Coleman, P. J., ed., The western Pacific-island arcs, marginal seas, geochemistry: New York, Crane, Russak and Co., Inc., p. 389-406.

Stach, L. W., 1947, Petroleum exploration and production in western Pacific during World War II: American Assocation of Petroleum Geologists Bulletin, v. 31, no. 8, p. 1384-1403.

\section{$\underline{\text { Pakistan }}$}

Ahmed, S. S., 1969, Tertiary geology of part of south Makran, Baluchistan, West Pakistan: American Association of Petroleum Geologists Bulletin, v. 53, no. 7, p. 1480-1499.

Auldridge, L., 1975, Pakistan oil search gaining momentum: 011 and Gas Journal, v. 73 , no. 18, p. 152-153.

Drilling-DCW, 1975, New lure in Pakistan: Drilling-DCW, April 20, p. $62-65$.

Meissner, C. R., Jr., and Rahman, H. 1973, Distribution, thickness and lithology of Paleocene rocks in Pakistan: U.S. Geological Survey Professional Paper 716E (plate 1).

Rahman, H., 1963, Geology of petroleum in Pakistan: World Petroleum Congress, 6th, Frankfurt-am-Main, 1963, Proceedings, sec. 1, p. 659-683.

\section{Philippines}

Corby, G. W., and others, 1951, Geology and oil possibilities of the Philippines: Manila, Department of Agriculture and Natural Resources, $363 \mathrm{p}$.

Gervasio, F. C., 1973, Geotectonic development of the Philippines, in Coleman, P. J., ed., The western Pacific--island arcs, marginal seas, geochemistry: New York, Crane, Russak and Co., Inc., p. 307-324. 
Kintanar, E. R. L., 1966, Petroleum geology of the Philippines: Paper presented to 2nd Geol. Convention and 1st Symposium on the Geology of the Mineral Resources of the Philippines and Neighboring Countries (October 1966).

Merrill, W. R., and McNaughton, D. A. 1962, Geology and exploration in the Philippines: Paper presented to National Convention of the American Association of Petroleum Geologists, San Francisco (March 1962).

Robertson Research International, 1975, Petroleum prospects in the Philippines: Robertson Research International News, Issue 2, p. 3.

Sheldon, R. A., 1973, Stratigraphy and petroleum prospects of southwestern Cebu, Philippines: American Association of Petroleum Geologists Bulletin, v. 57, no. 7, p. 1343-1347.

Tamesis, E. V., and others, 1973, Late Tertiary geologic history of the continental shelf off northwestern Palawan, Philippines: Geological Society of Malaysia Bulletin 6, p. 165-176.

South China Sea

Blake, J. K., 1974, South China Sea survey holds good promise of oil and gas: Petroleum International, v. 14, no. 7 , p. 31-32.

Emery, K. O., and Ben-Avraham, Z., 1972, Structure and stratigraphy of China Basin: American Association of Petroleum Geologists Bulletin, v. 56, no. 5, p. 839-859.

Parke, M. L., and others, 1971, Structural framework of continental margin in South China Sea: American Association of Petroleum Geologists Bulletin, v. 55, no. 5, p. 723-751.

South Vietnam

International Petroleum Consultants, 1976, South Veitnam, sypppsis 1975: International Petroleum Consultants, scale $1: 2,000,000$. -

Thailand

Javanaphet, J. C., 1969, Geological map of Thailand: Thailand Department of Mineral Resources, scale 1:1,000,000.

Sundharovat, S., 1964, Report on the geology of oil, oil shale, and coal, in the Tertiary basins of northern Thailand with a hypothesis on the origin of the oil of probable non-marine origin: Thailand, Department of Mineral Resources, $37 \mathrm{p}$.

17 Available only from Petroconsultants, SA, 2 Rue Vallin 1211 Geneva 11, Switzerland. 


\section{Turkey}

Campbe11, A. S., ed., 1971, Geology and history of Turkey: Petroleum Exploration Society of Libya, 13th Annual Field Conference, 511 p.

Erentoz, C., and Ternek, Z., 1959, Oil possiblities in the sedimentary basins of Turkey: World Petroleum Congress, 5th, New York, 1959, Proceedings, sec. 1, p. 295-309.

Gonulden, P., 1970a, An outline of the oil basins of Turkey: 0il and Gas Journal, v. 65, no. 33, pt. 1, p. 100-105.

1970b, An outline of the oil basins of Turkey: 0il and Gas Journal, v. 65 , no. 34 , pt. 2, p. 94-95.

International Petroleum Consultants, 1974, Turkey, synopsis 1973 : International Petroleum Consultants, scale $1: 2,000,000$.

Oil and Gas Journal, 1970a, An outline of the oil basins of Turkey: The 0il and Gas Journal, v. 68, no. 33, part 1, p. 100-105.

1970b, An outline of the oil basins of Turkey: The

Oil and Gas Journal, v. 68, no. 34, part 2, p. 94-95.

Temple, P. G., and Perry, L. J., 1962, Geology and oil occurrence, southeast Turkey: American Association of Petroleum Geologists Bulletin, v. 46, no. 9, p. 1596-1612.

\section{USSR--general}

Avrov, V. Y., and others, 1967, Map of prospective oil and gas regions of the USSR: Moscow, Ministry Geology of USSR, Ministry Oil Industry of USSR, and Ministry Gas Industry of USSR, scale 1:5,000,000, 4 sheets.

Bakirov, A. A., and Ryabukhin, G. E., eds., 1969, $0 i 1$ and gas provinces and districts of the USSR: Moscow, Nedra, $478 \mathrm{p}$.

Burk, C. A., 1975, Sea of Okhotsk--thirteenth cruise of the Dmitry Mendeleev: Geology, v. 3, no. 3, p. 141-144.

Burlin, Y. K., 1975, Sedimentary basins of the Far East and the northeast of the USSR and their possible oil and gas content: World Petroleum Congress, 9th, Tokyo 1975, Proceedings, v. 3, p. 39-50.

Chapelle, J. and Ketchian, S., 1963, URSS - Second Producteur de Pétrole du Monde: Publications de L'Institut Français du Pétrole, Collection Science et Technique du Pétrole No. 4, Paris, Editions Technip, $314 \mathrm{p}$.

If Available only from Petroconsultants, SA, 2 Rue Vallin - 1211

Geneva 11, Switzerland. 
Eremenko, N. A., and others, 1970, Map of prospective oil and gas areas of the USSR shelf: Moscow, Academy of Science, USSR, Ministry of Geology, USSR, Ministry of oil industry, USSR, and Azerbaydzhan Academy of Science, scale 1:5,000,000, 3 sheets.

Eremenko, N. A., and others, 1971, Oil and gas prospects of the shelf of the USRR: World Petroleum Congress, 8th, Moscow, 1971, Proceedings, v. 2, p. 121-129.

1973, Geologic structure and oil and gas prospects of USSR continental shelf: American Association of Petroleum Geologists Bulletin, v. 57, no. 2, p. 235-243.

Fedynskiy, V. V., and Levin, L. E., eds., Billings, M. P., ed. of the English-language Edition, 1970, The Tectonics and 011 and Gas Potential of the Marginal and Inland Seas of the USRR: New York, Lamont-Doherty Geological Observatory of Columbia University, 301 p.

Fohs, F. J., 1947, Oil reserve provinces of Middle East and southern Soviet Russia: American Association of Petroleum Geologists Bulletin, v. 31 , no. 8 , p. 1372-1383.

Geodekyan, A. A., and others, 1975, Geological-geochemical evaluation of possible oil and gas content of the Bering Sea, the Seas of Okhotsk and Japan, the northwestern Pacific and the Arctic Ocean: World Petroleum Congress, 9th, Tokyo 1975, Proceedings, v. 2, p. 337-346.

International Petroleum Consultants, 1974a, Structural prospect map of the northern part of central Siberia (East Siberian Platform): Review of Sipg-Soviet 0il, v. 9, no. 7, Enclosure 1, scale $1: 2,500,000$.

1975a, Irkutsk Amphitheater: Review of Sino-Soviet 0il, v. 10, no. 6, Enclosure 2, Scale 1:5,000,000.

1975b, Structural/prospect map of the northern part of western Siberia (Map of gas figlds): Review of Sino-Soviet 0il, v. 10, no. 8 , scale $1: 2,500,000$.

King, R. E., 1975, Petroleum exploration and production in Europe in 1974: American Association of Petroleum Geologists Bulletin, v. 59, no. 10 , P. 1870 .

McDowell, A. N., 1975, What are the problems in estimating the oil potential of a basin?: Oil and Gas Journal, v. 73, no. 23, p. 8590.

If Available only from Petroconsultants, SA, 2 Rue Vallin - 1211

Geneva 11, Switzerland. 
Meyerhoff, A. A., 1973, Geopolitical implication of Russian and.Chinese petroleum, in Cameron, V. S., ed., Exploration and economics of the petroleum industry, Volume II: New York, Matthew Bender and Co., p. 79-127.

Nieyerhoff, H. A., and Meyerhoff, A. A., 1973, Arctic geopolitics, in Pitcher, M. G., ed., Arctic geology: American Association of Petroleum Geologists Memoir 19, p. 646-670.

Nalivkin, V. D., ed.-in-chief, 1969, Tectonic map of oil and gas deposits of USSR: USSR, Ministry of Geology, scale $1: 2,500,000,16$ sheets.

Oil and Gas Journal, 1974a, Japanese have new oil target--promising Sakhalin Island: $0 i l$ and Gas Journal, v. 72, no. 23, p. 94-96. 1974b, Russia looks at deep drilling in Fergana Valley: 0 il and Gas Journal, v. 72 , no. 46, p. 107.

Ovaesov, G. P., and others, 1975, Palaeodeltaic sediments and methods of petroleum exploration in the USSR: World Petroleum Congress, 9th, Tokyo, 1975, Proceedings, v. 2, p. 229-238.

Ovcharenko, A. V., and Sevost'yanov, K. M., 1975, 0il-gas prospects and plans for further exploration in Kamchatka: Petroleum Geology, v. 12 , no. 5, p. 535-537.

Sarkisyan, S. G., Politykina, M. A., and Chilingarian, G. V., 1973, Effect of post-sedimentation processes on carbonate reservoir rocks in Volga-Urals region, USSR: American Association of Petroleum Geologists Bulletin, v. 57, no. 7, p. 1305-1313.

Sememovich, V. N., and Erofeev, N. S., 1971, New oil and gas regions of the USSR and their prospects: World Petroleum Congress, 8th, Moscow 1971, Proceedings, v. 2, p. 293-300.

Shabad, T. and Mote, V. L., 1977, Gateway to Siberian resources (The BAM): John Wiley and Sons, New York, 189 p.

Spizharsky, T. N., ed.-in-chief, 1964, Tectonic map of the USSR: Ministry of Geology, USSR, scale 1:2,500,000, 16 sheets (3-sheet legend in English).

Stowell, C. E., 1974, 0il and Gas Development in the USSR: Tulsa, The Petroleum Publishing Company, 48 p.

Terman, M. J., 1975, Work maps of sedimentary basins of Asia and the USSR: Unpublished work maps, scale 1:5,000,000.

Terman, M. J., and Woo, C. C., 1967, China and Mongolia, in Atlas of the Sino-Soviet Bloc to support detection of underground nuclear testing, Volume 2, Tectonics: U.S. Geological Survey, scale 1:5,000,000. 
Trofimuk, A. A., ed., 1971, Oil and gas prospective basins of the far eastern USSR: Moscow, Nedra, $184 \mathrm{p}$.

USSR Ministry of Geology, 1961, Tectonic map of USSR: USSR, Ministry of Geology, scale $1: 10,000,000$.

Zverev, S. M., and Tulina, Y. V., 1973, Peculiarities in the deep structure of the Sakhalin-Hokkaido-Primorye Zone: Tectonophysics, v. 20, no. 1-4, p. 115-127.

USSR--Anadyr'

Burlin, Y. K., Dontsov, V. V., and Pastukhova, T. N., 1975, Further direction of oil exploration in northeastern USSR: Petroleum Geology, v. 12, no. 5, p. 222-223.

Kostylev, Y. N., and Burlin, Y. K., 1966, Geologic evolution of the Anadyr' Depression: Akademii Nauk SSSR, Doklady, v. 166, no. 5, p. 1177-1179.

Meyerhoff, A. A., 1972a, Russians look hard at the Anadyr' Basin: 0il and Gas Journal, v. 70 , no. 43, pt. 1, p. 124-129.

$1972 \mathrm{~b}$, Russians look hard at the Anadyr' Basin: $0 i 1$ and Gas Journal, v. 70, no. 44, pt. 2, p. 84-89.

$\underline{\text { USSR--Arctic }}$

Bakke, D. R., 1976, Russia begins to tap its biggest reserves off Siberia: Offshore, v. 36, no. 4, p. 63-67.

Bondarev, V. I., and others, 1973, Geologic structure of Novaya Zemlya, Vaygach, Pay-Khoy, Polar Urals, and northern Pechora, in Pitcher, M. G., ed., Arctic geology: American Association of Petroleum Geologists Memoir 19, p. 301-316.

Churkin, M., Jr., 1970, Fold belts of Alaska and Siberia and drift between North America and Asia, in Geological Seminar on the North Slope of Alaska, California, 1970, Proceedings: Los Angeles, American Association of Petroleum Geologists, Pacific Section, p. G1-G17.

Lebedev, I. I., and others, 1975, Sedimentary basins of the submarine margin of north Europe and their oil and gas prospects, in Yorath, C. J., Parker, E. R., and Glass, D. J., eds., Canada's continental margins and offshore petroleum exploration: Canadian Society of Petroleum Geologists Memoir 4, p. 257-265.

Semenovich, V. N., Gramberg, I. S., and Nesterov, I. I., 1973, 0i1 and gas possibilities in the Soviet Arctic, in Pitcher, M. G., ed., Arctic geology: American Association of Petroleum Geologists Memoir 19, p. 194-203. 
Sokolov, B. A., 1976, Geologic structure and petroleum potential of the arctic segment, in Sokolov, B. A. and others, Petroleum Resources of Seas and Oceans: Moscow, Mir Publishers, Chapter 10, p. 215239.

\section{USSR--Baltic}

Bakirov, A. A., and Ryabukhin, G. E., eds., 1969, 0 il and Gas Provinces and Districts of the USSR: Moscow, Nedra, p. 170.

\section{Yellow Sea}

Emery, K. 0., and others, 1970, Geological structure and some water characteristics of the East China Sea and the Yellow Sea: Petroleum Geology Taiwan, no. 7, p. 243-279.

Frazier, S. B., Schwartz, D., Cronk, C., and Choi, S. 0., 1972, Petroleum exploration survey over a portion of the Yellow Sea: International Geological Congress, 24th, Montreal, 1972, Proceedings, sec. 5, p. 135-141.

Wageman, J. M., Hilde, T. W. C., and Emery, K. 0., 1970, Structural framework of East China Sea and Yellow Sea: American Association of Petroleum Geologists Bulletin, v. 54, no. 9, p. 1611-1643. 
Australasia

Australia

Allen, R. J., 1974, Hydrocarbon significance of upper Palaeozoic sediments associated with the Koburra Trough, Galilee Basin: Australian Petroleum Exploration Association Journal, v. 14, pt. 1, p. 59-65.

Australia Bureau of Mineral Resources, 1952, Geological map of Australia and New Guinea: Australia, Bureau of Mineral Resources, Geology and Geophysics, scale 1:6,336,000.

Australia, Geological Society of, 1971, Tectonic map of Australia and New Guinea: Geological Society of Australia, scale 1:5,000,000.

Beddoes, L. R., Jr., ed., 1973, $0 i 1$ and gas fields of Australia, Papua New Guinea and New Zealand: Australia, Tracer Petroleum and Mining Publications Pty. Ltd., 382 p.

1965, Geological map of the world, Australia and Oceania: Australia, Bureau of Mineral Resources, Geology and Geophysics, scale $1: 5,000,000$.

Cameron, J. C., 1967, Australia's oil and gas potential--a review of the main sedimentary basins: World Petroleum Congress, 7 th, Mexico City, 1967, Proceedings, v. 2, p. 152-160.

Exon, N. 1974, The geological evolution of the southern Taroom Trough and the overlying Surat Basin: Australian Petroleum Exploration Association Journal, v. 14, pt. 1, p. 50-59.

Hogetoorn, D. J., 1967, Jurassic reservoir of the Surat Basin: World Petroleum Congress, 7 th, Mexico City, 1967, Proceedings, v. 2, p. 161-170.

Kraus, G. P. and Laws, R. A., 1974a, Regional geology of Bonaparte GulfTimor Sea area of northwest Australia, Part 1: $0 i l$ and Gas Journal, v. 72 , no. 46 , p. 98-101.

1974b, Regional geology of Bonaparte Gulf-Timor Sea area of northwest Australia, Part 2: $0 i 1$ and Gas Journal, v.72, no. 47, p. 160-162.

Leslie, R. B., Evans, H. J., and Knight, C. L., eds., 1976, Economic Geology of Australia and Papua New Guinea -- Volume 3, Petroleum: Parkville, Victoria, Australia, The Australasian Institute of Mining and Metallurgy, Monograph Series no. 7, 541 p.

Lofting, M. J. W., Crostella, A., and Halse, J. W., 1975, Exploration results and future prospects in the northern Australasian region: World Petroleum Congress, 9th, Tokyo, 1975, Proceedings, v. 3, p. 65-81.

Powell, T. G., and McKirdy, D. M., 1975, Crude oil composition in Australia and Papua, New Guinea: American Association of Petroleum Geologists Bulletin, v. 59, no. 7, p. 1176-1197. 
Power, P. E., and Devine, S. B., 1970, Surat Basin, Australia-subsurface stratigraphy, history and petroleum: American Association of Petroleum Geologists Bulletin, v. 54, no. 12, p. 2410-2437.

Rayner, J. M., 1969, Governmental activities in petroleum exploration: Australian Petroleum Exploration Association Journal, v. 9, pt. 2, p. 23-30.

Richards, K. A., and Hopkins, B. M., 1971, Offshore exploration for petroleum in the Gippsland, Bass and Otway Basins, southeastern Australia, in Case histories of oil and gas fields in Asia and the Far East (3rd series): United Nations Economic Committee for Asia and Far East, Mineral Resources Development Series, no. 37, p. 1328.

Rudd, E. A., and Kear, D., 1966, Petroleum developments in southwest Pacific region during 1965: American Association of Petroleum Geologists Bulletin, v. 50, no. 8, p. 1782-1791.

Sander, N. J., Humphrey, W. E., and Mason, J. F., 1975, Tectonic framework of southeast Asia and Australia--Its significance in the occurrence of petroleum: World Petroleum Congress, 9th, Tokyo, 1975, Proceedings, v. 3, p. 83-105.

Siller C. W., 1967, Exploration leading to the discovery of the Mereenie field, Amadeus Basin, central Australia, and its subsequent development, in Case histories of oil and gas fields in Asia and the Far East (2nd series): United Nations Economic Committee for Asia and Far East, Mineral Resources Development Series, no. 29, p. 9-18.

Thomas, B. M., and Smith, D. N., 1974, A summary of the petroleum geology of the Carnarvon Basin: Australian Petroleum Exploration Journal, v. 14, pt. 1, p. 66-70.

1975, Australia's Carnarvon Basin has successful exploration background: $0 i 1$ and Gas Journal, v. 73, no. 18, p. 292-294.

Williams, L. W., Forman, D. J., and Hawkins, P. J., 1975, Appraisal of the Sahul Shelf needed: 0 il and Gas Journal, v. 73, no. 21, p. 128-130.

Wopfner, H., 1967, Case history of the Gidgealpa gas field, south Australia, in Case histories of oil and gas fields in Asia and the Far East (2nd series): United Nations Economic Committee for Asia and Far East, Mineral Resources Development Series, no. 29, p. 34-52.

1970, Early Cambrian paleogeography, Frome Embayment south Australia: American Association of Petroleum Geologists Bulletin, v. 54, no. 12 , p. 2395-2409. 


\section{New Guinea}

Australia Bureau of Mineral Resources, 1952, Geological map of Australia and New Guinea: Australia, Bureau of Mineral Resources, Geology and Geophysics, scale 1:6,336,000.

Australia, Geological Society of, 1971, Tectonic map of Australia and New Guinea: Geological Society of Australia, scale 1:5,000,000.

Beddoes, L. R., Jr., ed., 1973, Oil and gas fields of Australia, Papua New Guinea and New Zealand: Australia, Tracer Petroleum and Mining Publications Pty. Ltd., 382 p.

Leslie, R. B., Evans, H. J., and Knight, C. L., eds., 1976, Economic Geology of Australia and Papua New Guinea -- Volume 3, Petroleum: Parkville, Victoria, Australia, The Australasian Institute of Mining and Metallurgy, Monograph Series no. 7, 541 p.

Powell, T. G., and McKirdy, D. M., 1975, Crude oil composition in Australia and Papua, New Guinea: American Association of Petroleum Geologists Bulletin, v. 59, no. 7, p. 1176-1197.

Rayner, J. M., 1969, Governmental activities in petroleum exploration: Australian Petroleum Exploration Association Journal, v. 9, pt. 2, p. 23-30.

New Zealand

Austin, P. M., Sprigg, R. C., and Braithwaite, J. C., 1973, Structure and petroleum potential of Eastern Chatham Rise, New Zealand:

American Association of Petroleum Geologists Bulletin, v. 57, no. 3 , p. 477-497.

Beddoes, L. R. Jr., 1973, Oil and gas fields of Australia, Papua New Guinea and New Zealand: Australia, Tracer Petroleum and Mining Publications Pty. Ltd., 382 p.

International Petroleum Consultants, 1975a, New Zealand, North Island, synopsis first half 1975 : International Petroleum Consultants, scale $1: 1,000,000$.

1975b, New Zealand, South Island, synopsis first half 1975:

International Petroleum Consultants, scale, $1: 1,000,000.1$

Katz, H. R., 1968, Potential oil formations in New Zealand and their stratigraphic position as related to basin evolution: New Zealand Journal of Geology and Geophysics, v. 11, no. 5, p. 1077-1133.

If Available only from Petroconsultants, SA, 2 Rue Vallin - 1211 Geneva 11, Switzerland. 
1974a, Margins of the southwest Pacific, in Burk, C. A., and Drake, C. L., eds., The Geology of Continental Margins: New York, Springer-Verlag, p. 549-565.

1974b, Offshore petroleum potential in New Zealand: Australian Petroleum Exploration Assocation Journal, v. 14, pt. 1, p. 3-13.

Kear, D., 1967, The Kapuni gas-condensate field, New Zealand--a case study, in Case histories of oil and gas fields in Asia and the Far East (2nd series): United Nations Economic Committee for Asia and Far East, Mineral Resources Development Series, no. 29, p. 86-91.

New Zealand Geological Survey, 1958, Geological map of New Zealand: New Zealand Geological Survey, scale 1:2,000,000.

1972a, Geological map of New Zealand, North Island: New Zealand Geological Survey, scale 1:1,000,000.

1972b, Geological map of New Zealand, South Island: New Zealand Geological Survey, scale 1:1,000,000.

Robertson Research International, Ltd., 1975, New Zealand, Petroleum prospects of the onshore Taranaki Basin: Robertson Research International Ltd., p. 2 of informal memo.

Sprigg, R. C., and others, 1969, $0 i 1$ and gas prospects of southern Taranaki Bight, New Zealand: American Association of Petroleum Geologists Bulletin, v. 53, no. 9, p. 1956-1977. 
Central America - Caribbean

\section{Caribbean--General}

Byramjee, R. S., Mugniot, J. F., and Duval, B. B., 1975, Petroleum potential of deep-water areas of the Mediterranean and Caribbean Seas: World Petroleum Congress, 9th, Tokyo, 1975, Proceedings, v. 2, p. 299-312.

Case, J . E., 1975, Basin and province map, Caribbean area: Unpublished work map, scale 1:5,000,000.

Christofferson, E., 1973, Linear magnetic anomalies in the Colombia Basin, central Caribbean Sea: Geological Society of America Bulletin, v. 84 , no. 10, p. $3217-3230$.

Ewing, J. I., and others, 1957a, Geophysical investigations in the eastern Caribbean--Venezuela Basin, Antilles Island arc, and Puerto Rico Trench: Geological Society of America Bulletin, v. 68, no. 3, p. 359-378.

1957b, Geophysical investigations in the eastern Caribbean-Trinidad Shelf, Tobago Trough, Barbados Ridge, Atlantic Ocean: Geological Society of America Bulletin, v. 68, no. 7, p. 897-912.

Holcombe, T. L., and Matthews, J. E., 1972, Structural fabric of the Venezuela Basin, Caribbean Sea: Geological Society of America Abstracts with Programs, v. 5, no. 7, p. 671-672.

Robinson, E., and Cambray, F. W., 1971, Physiography of the sea floor east of Jamaica, in Symposium on investigations and resources of the Caribbean Sea and adjacent regions: United Nations Educational, Scientific, Cultural Organization, Paris, 1971, p. 285-289.

United Nations, 1971, Symposium on investigations and resources of the Caribbean Sea and adjacent regions: United Nations Educational Scientific, Cultural Organization, Paris, 545 p.

Winston, G. 0., 1971, Regional structure, stratigraphy, and oil possibilities of the South Florida Basin: Transactions of Gulf Coast Association of Geological Societies, v. 21, p. 15-29.

Woodring, W. P., 1954, Caribbean land and sea through the ages: Geological Society of America Bulletin, v. 65, no. 8, p. 719-732.

Central America--General

Dengo, G., and Bohnenberger, Q., 1969, Structural development of northern Central America, in Logan, B. W., and others, eds., Carbonate sediments and reefs, Yucatan Shelf, Mexico; tectonic relations of northern Central America and the western Caribbean; and other papers on Florida and British Honduras: American Association of Petroleum Geologists Memoir 11, p. 203-220. 
Imlay, R. W., 1944, Cretaceous formations of Central America and Mexico: American Association of Petroleum Geologists Bulletin, v. 28, no. 8, p. 1077-1195.

Lluyd, J. J., 1963, Tectonic history of the south Central American orogen, in Childs, 0. E., and Beebe, B. W., eds., Backbone of the Americas: American Association of Petroleum Geologists Memoir 2, p. 88-112.

Vinson, G. L., and Brineman, J. H., 1963, Nuclear Central America, hub of Antillean transverse belt, in Childs, 0. E., and Beebe, B. W., eds., Backbone of the Americas: American Association of Petroleum Geologists Memoir 2, p. 101-112.

\section{Antilles}

Butterlin, J., 1956, La constitution géologique et la structure des Antilles: Centre National de la Recherche Scientifique, $453 \mathrm{p}$.

Christman, R. A., 1953, Geology of St. Bartholomew, St. Martin and Anguilla, Lesser Antilles: Geological Society of America Bulletin, v. 64 , no. 1, p. 65-96.

Weeks, L. A., and others, 1971, Structural relations among Lesser Antilles, Venezuela and Trinidad-Tobago: American Association of Petroleum Geologists Bulletin, v. 55, no. 10, p. 1741-1752.

\section{$\underline{\text { Barbados }}$}

Renz, H. H., 1942, Stratigraphy of northern South America, Trinidad, and Barbados: American Scientific Congress, 8th, Washington D.C., 1940, Proceedings, v. 4, p. 513-571.

\section{Belize (British Honduras)}

Dillon, W. P., and Vedder, J. G., 1973, Structure and development of the continental margin of British Honduras: Geological Society of America Bulletin, v. 84, no. 8, p. 2713-2732.

\section{Costa Rica}

Chaves, R., and others, collaborators, 1968, Mapa geologico de Costa Rica: Direccion de Geologia, Minas y Petroleo, scale 1:700,000, 1 sheet.

Redfield, A. H., 1923, The petroleum possibilities of Costa Rica: Economic Geology, v. 18, no. 4, p. 354-381.

$\underline{\text { Cuba }}$

Furrazola-Bermudez, G., and others, 1968, Geology of Cuba: Washington, D. C., U.S. Department of Commerce, Joint Publication Research Service Translation on Cuba, no. 311, 207 p. 
Hatten, C. W., 1967, Principal features of Cuban geology--discussion: American Association of Petroleum Geologists Bulletin, v. 51, no. 5, p. 780-789.

Khudoley, K. M., 1967, Principal features of Cuban geology: American Association of Petroleum Geologists Bulletin, v. 51, no. 5, p. 668677.

\section{Dominican Republic}

Bowin, C. 0., 1966, Geology of central Dominican Republic, in Hess, H. H., ed., Caribbean geological investigations: Geological Society of America Memoir 98, p. 11-84.

Republica Dominicana, 1967, Mapa geologico preliminar: Organanizacion de los Estados Americanos, scale 1:250,000, 1 sheet.

\section{E1 Salvador}

Weber, H. S., Wiesemann, G., and Wittekindt, H., eds., 1974, Mapa geologico general de la Republica de E1 Salvador: Hannover, Bundesanstalt Bodenforschung, scale 1:500,000, 1 sheet.

\section{Guatemala}

Guatemala, Republic of, 1970, Mapa geologico de la Republica de Guatemala: Instituto Geografico Nacional--Guatemala, scale 1:500,000, 4 sheets.

Kornicker, L. S., and Bryant, W. R., 1969, Sedimentation on continental shelf of Guatemala and Honduras, in McBirney, A. R., ed., Tectonic relations of northern Central America and the western Caribbean, The Bonacca Expedition: American Association of Petroleum Geologists Memoir 11, [Part 2], p. 244-257.

McBirney, A. R., 1963, Geology of a part of the central Guatemalan Cordillera: University of California Publications in Geological Sciences, v. 38, p. 177-242.

Richards, H. G., 1963, Stratigraphy of earliest Mesozoic sediments in southeastern Mexico and western Guatemala: American Association of Petroleum Geologists Bulletin, v. 47, no. 10, p. 1861-1870.

Vinson, G. L., 1962, Upper Cretaceous and Tertiary stratigraphy of Guatemala: American Association of Petroleum Geologists Bulletin, v. 46 , no. 4, p. $425-456$.

Walper, J. L., 1960, Geology of Cuban-Purhula area, Alta Verapaz, Guatemala: American Association of Petroleum Geologists Bulletin, v. 44, no. 8, p. 1273-1315. 
Williams, H., McBirney, A. R., and Dengs, G., 1944, Geologic reconnaissance of southeastern Guatemala: University of California Publications in Geological Sciences, v. 50, p. 1-56.

\section{Guyana}

Choubert B., (principal collaborateur) 1960, Carte géologique du Department de la Guyane: Service de la Carte Géologique de la France, scale $1: 500,000,2$ sheets.

Honduras

Kornicker, L. S., and Bryant, W. R., 1969, Sedimentation on continental shelf of Guatemala and Honduras, in McBirney, A. R., ed., Tectonic relations of northern Central America and the western Caribbean, The Bonacca Expendition: American Association of Petroleum Geologists Memoir 11, [part 2] p. 244-257.

\section{Nicaragua}

Nicaragua, Republica de, 1973, Republica de Nicaragua--mapa geologico: Instituto Geografico Nacional, Nicaragua, scale $1: 1,000,000,1$ sheet.

\section{Puerto Rico}

Almy, C. C., Jr., 1969, Sedimentation and tectonism in the upper Cretaceous Puerto Rican portion of the Caribbean Island arc: Gulf Coast Association of Geological Societies Transactions, v. 19, p. 269279.

Briggs, R. P., 1964, Provisional geologic map of Puerto Rico and adjacent islands: U.S. Geological Survey Miscellaneous Geological Investigations Map I-392, scale 1:240,000.

Ewing, M., and Heezen, B. C., 1955, Puerto Rico trench topographic and geophysical data, in Poldervaart, A., ed., Crust of the earth: Geological Society of America Special Paper 62, p. 255-267.

\section{$\underline{\text { Trinidad }}$}

Barr, K. W., Waite, S. T., and Wilson, C. C., 1958, The mode of oil occurrence in the Miocene of southern Trinidad, BWI, in Weeks, L. G., ed., Habitat of oil, a symposium: American Association of Petroleum Geologists, p. 533-550.

Bassinger, B. G., Harbison, R. N., and Weeks, L. A., 1971, Marine geophysical study northeast of Trinidad-Tobago: American Association of Petroleum Geologists Bulletin, v. 55, no. 10, p. 1730-1740. 
Renz, H. H., 1942, Stratigraphy of northern South America, Trinidad, and Barbados: American Scientific Congress, 8th, Washington, D. C., 1940, Proceedings, v. 4, p. 513-571.

Suter, H. H., 1960, The General and Economic Geology of Trinidad, British West Indies: London, Her Majesty's Stationary Office, 145 p.

Weeks, L. A., and others, 1971, Structural relations among Lesser Antilles, Venezuela and Trinidad-Tobago: American Association of Petroleum Geologists Bulletin, v. 55, no. 10, p. 1741-1752. 
Europe

Europe--general

Congrés Géologique International, 1962, Carte tectonique internationale de 1'Europe: Congrés Geologique International, Commission de la carte géologique du monde, Sous-commission de la carte tectonique du monde, scale $1: 2,500,000,16$ sheets.

Gaertner, H. R. V., and Walther, H. W., Coordinators, 1971, International geological map of Europe and the Mediterranean region: International Geological Congress--Commission for the geological map of the world, Bundesanstalt für Bodenforschung and United Nations Educational, Scientific, Cultural Organization, scale 1:5,000,000.

Geological Institute of Dionyz Stúr and United Nations Educational, Scientific, Cultural Organization, 1973, Tectonic map of the Carpathian Balkan Mountain systems and adjacent areas: Geological Institute of Dionýz Stúr and United Nations Educational, Scientific, Cultural Organization, scale 1:1,000,000.

Kent, P. E., 1969, The geological framework of petroleum exploration in Europe and North Africa and the implications of continental drift hypothesis, in Hepple, P., ed., The exploration for petroleum in Europe and North Africa: London, Institute of Petroleum, p. 3-17.

Lebedev., L. I., and others, 1975, Sedimentary basins of the submarine margin of north Europe and their oil and gas prospects, in Yorath, C. J., Parker, E. R., and Glass, D. J., eds., Canada's continental margins and offshore petroleum exploration: Canadian Society of Petroleum Geologists Memoir 4, p. 257-265.

Meyerhoff, A. A., 1973, Origin of Arctic and north Atlantic Oceans, in Pitcher, M. G., ed., Arctic geology: American Association of Petroleum Geologists Memoir 19, p. 562-582.

Meyerhoff, H. A., and Meyerhoff, A. A., 1973, Arctic geopolitics, in Pitcher, M. G., ed., Arctic geology: American Association of Petroleum Geologists Memoir 19, p. 646-670.

Naylor, D., and Mounteney, S. N., 1975, Geology of the northwest European continental shelf: London, Graham, Trotman, Dudley, Ltd., v. 1, $162 \mathrm{p}$.

Pegrum, R. M., Rees, G., and Naylor, D., 1975, Geology of the northwest European continental shelf: London, Graham, Trotman, Dudley, Ltd., v. 2 , $225 \mathrm{p}$.

Sokolov, B. A., 1976, Geologic structure and petroleum potential of the arctic segment, in Sokolov, B. A. and others, Petroleum Resources of Seas and Oceans: Moscow, Mir Publishers, Chapter 10, p. 215-239. 
Thomas, T. M., 1975, Search for hydrocarbons in shelf seas of northwest Europe: American Association of Petroleum Geologists Bulletin, v. 59, no. 4, p. 573-617.

United Nations, 1972, International map of natural gas fields of Europe: United Nations Economic Commission for Europe, Committee on Gas, scale $1: 2,500,000$.

\section{Black Sea}

Neprochnov, Y. P., Neprochnova, A. F., and Mirlin, Y. G., 1972, Deep structure of Black Sea Basin in Degans, E. T. and Ross, D. A., eds., the Black Sea--geology, chemistry and biology: American Association of Petroleum Geologists Memoir 20, p. 35-49.

Ross, D. A., 1974, The Black Sea, in Burk, C. A., and Drake, C. L., eds., The Geology of Continental Margins: New York, SpringerVerlag, p. 669-682.

Ross, D. A., Uchupi, E., and Bowin, C. O., 1972, Shallow structure of Black Sea, in Degens, E. T., and Ross, D. A., eds., The Black Sea-geology, chemistry and biology: American Association of Petroleum Geologists Memoir 20, p. 11-34.

Greenland

Birkelund, T., and others, 1974, An outline of the geology of the Atlantic Coast of Greenland, in Nairn, A. E. M., and Stehli, F. G., eds., The Ocean Basins and Margins, Volume 2, The North Atlantic: New York, Plenum Press, p. 125-159.

Denham, L. R., 1974, Offshore geology of northern west Greenland (69 ${ }^{\circ}$ to $\left.75^{\circ} \mathrm{N}\right)$ : Greenland Geological Survey Report, no. 63, 24 p.

Escher, A., and others, 1970, Tectonic/geologic map of Greenland: Geological Survey of Greenland, scale 1:2,500,000.

Gaffney, P. D., 1974, The geology of the northwest Europe marine area: Southeast Asia Petroleum Exploration Society, Proceedings, v. 1, p. 64-80.

Haller, J., 1971, Geology of the east Greenland Caledonides: New York, Interscience Publishers, $413 \mathrm{p}$.

Henderson, G., 1969, 011 and gas prospects in the Cretaceous-Tertiary basin of west Greenland: Grфnlands Geologiske Unders $\phi g e l s e$, Rapp. no. 22 , p. 5-50.

Henderson, G., and Stevens, N. B. H., 1969, Note on oil and gas prospects in west Greenland: Geological Survey of Greenland, Information Circular (unnumbered), $14 \mathrm{p}$. 
Johnson, G. L., McMillan, N. J., and Egloff, J., 1975, East Greenland continental margin, in Yorath, C. J., Parker, E. R., and Glass, D. J., eds., Canada's continental margins and offshore petroleum exploration: Canadian Society of Petroleum Geologists Memoir 4, p. 205-224.

Soper, N. J., and others, 1976, Late Cretaceous-early Tertiary stratigraphy of the Kangerdlugssuaq area, east Greenland, and the age of opening of the northeast Atlantic: Quarterly Journal of the Geological Society of London, v. 132, pt. 1, p. 85-104.

Tatham, R. H., 1975, Surface-wave dispersion applied to the detection of sedimentary basins: Geophysics, v. 40, no. 1, p. 40-55.

\section{Hebrides Sea}

Smythe, D. K., and Kenolty, N., 1975, Tertiary sediments in the Sea of the Hebrides: Quarterly Journal of the Geological Society of London, v. 131, pt. 2, p. 227-233.

\section{Irish Sea}

Blundell, D. J., 1975, The geology of the Celtic Sea and Southwestern Approaches, in Yorath, C. J., Parker, E. R., and Glass, D. J., eds., Canada's continental margins and offshore petroleum exploration: Canadian Society of Petroleum Geologists Memoir 4, p. 341-362.

Colter, V. S., and Barr, K. W., 1975, Recent developments in the geology of the Irish Sea and Cheshire Basins, in Woodland, A. W., ed., Petroleum and the Continental Shelf of Northwest Europe, Volume 1: New York, John Wiley and Sons, p. 61-75.

Fletcher, B. N., 1975, A new Tertiary basin east of Lundy Island: Quarterly Journal of the Geological Society of London, v. 131, pt. 2, p. 223-225.

\section{Mediterranean}

Auzende, J. M., and 0livet, J. L., 1974, Structure of the western Mediterranean basin, in Burk, C. A., and Drake, C. L., eds., The geology of continental margins: New York, Springer-Verlag, p. 723731.

Biju-Duval, B., 1974, Geological and structural map of Tertiary basins in the Mediterranean domain: Revue de l'Institut Français du Pétrole, v. 29, no. 5, p. 607-639.

Biju-Duval, B., and others, 1974, Geology of the Mediterranean Sea basins, in Burk, C. A., and Drake, C. L., eds., The geology of continental margins: New York, Springer-Verlag, p. 695-721. 
Byramjee, R. S., Mugniot, J. F., and Duval, B. B., 1975, Petroleum potential of deep-water areas of the Mediterranean and Caribbean Seas: World Petroleum Congress, 9th, Tokyo 1975, Proceedings, v. 2, p. 299-312.

Gaertner, H. R. V. and Walther, H. W., Coordinators, 1971, International geological map of Europe and the Mediterranean region: International Geological Congress--Commission for the geological map of the world, Bundesanstalt für Bodenforschung and United Nations Educational, Scientific, Cultural Organization, scale 1:5,000,000.

Ross, D. A. and Uchupi, E., 1977, Structure and sedimentary history of southeastern Mediterranean Sea -- Nile Cone area: American Association of Petroleum Geologists Bulletin, v. 61, no. 6, p. 872902.

North Sea

Christian, H. E., 1969, Some observations on the initiation of salt structures of the southern British North Sea, in Hepple, P., ed., The exploration for petroleum in Europe and North Africa: London, Institute of Petroleum, p. 231-250.

Donovan, D. T., ed., 1968, Geology of shelf seas: Inter-university Geological Congress, 14th, Proceedings, London, Oliver and Boyd, $160 \mathrm{p}$.

Dunn, W. W., Eha, S., and Heikkila, H. H., 1973, North Sea is a tough theater for the oil-hungry industry to explore: Oil and Gas Journal, v. 71 , no. 2, p. 122-128.

Gaffney, P. D., 1974, The geology of the northwest Europe marine area: Southeast Asia Petroleum Exploration Society, Proceedings, v. 1, p. 64-80.

Gill, W. D., 1967, The North Sea Basin: World Petroleum Congress, 7th, Mexico City, 1967, Proceedings, v. 2, p. 211-219.

Hancock, J. M., and Scholle, P. A., 1975, Chalk of the North Sea, in Woodland, A. W., ed., Petroleum and the continental shelf of northwest Europe, Volume 1: New York, John Wiley and Sons, p. 413-428.

Hopkinson, J. P., and Nysaether, E., 1975, All geologic systems from Permian up represented in North Sea success story: 0 il and Gas Journal, v. 73 , no. 33, p. 158-161.

Kent, P. E., 1975, The tectonic development of Great Britain and the surrounding seas, in Woodland, A. W., ed., Petroleum and the Continental Shelf of Northwest Europe, Volume 1: New York, John Wiley and Sons, p. 3-28.

McCaslin, J. C., 1972, Europe's North Sea Basin has interesting neighbors: Oil and Gas Journal, v. 70, no. 50, p. 155. 
Watson, J. M., and Swanson, C. A., 1975, North Sea--major petroleum province: American Association of Petroleum Geologists Bulletin, v. 59, no. 7, p. 1098-1112.

Williams, J. J., Conner, D. C., and Peterson, K. E., 1975, Piper oil field, North Sea fault block structure with upper Jurassic beach/bar reservoir sands: American Association of Petroleum Geologists Bulletin, v. 59, no. 9, p. 1585-1601.

Ziegler, P. A., 1975, Geologic evolution of North Sea and its tectonic framework: American Association of Petroleum Geologists Bulletin, v. 59, no. 7, p. 1073-1097.

Norwegian-Greenland Sea

Eldholm, 0., and Windisch, C. C., 1974, Sediment distribution in the Norwegian-Greenland Sea: Geological Society of America Bulletin, v. 85 , no. 11, p. 1661-1676.

Norway

Ronnevik, H., and others, 1975, The geology of the Norwegian continental shelf, in Woodland, A. W., ed., Petroleum and the Continental Shelf of Northwest Europe, Volume 1: New York, John Wiley and Sons, p. 117-129.

Sundvor, E., and Nysaether, E., 1975, Geological outline of the Norwegian continental margin between $60^{\circ}$ and $68^{\circ} \mathrm{N}$, in Yorath, C. J., Parker, E. R., and Glass, D. J., eds., Canada's continental margins and offshore petroleum exploration: Canadian Society of Petroleum Geologists Memoir 4, p. 267-281.

\section{Portugal}

Montadert, L., and others, 1974, Continental margins of Galicia-Portugal and Bay of Biscay, in Burk, C. A., and Drake, C. L., eds., The geology of continental margins: New York, Springer-Verlag, p. 323-342.

Portugal Direccao Geral de Minas e Serviços Geologicos, 1972, Carta tectonica de Portugal: Direccao Geral de Minas e Serviços Geologicos, scale $1: 1,000,000$.

Uchupi, E., and others, 1976, Continental margin of western AfricaSenegal to Portugal: American Association of Petroleum Geologists Bulletin, v. 60 , no. 5, p. 809-878.

Spain

Querol, R., 1969, Petroleum exploration in Spain, in Hepple, P., ed., The exploration for petroleum in Europe and North Africa: London, Institute of Petroleum, p. 49-72. 
Sanz, R., 1967, Ayoluengo Field, southwest Cantabrian Basin, north central Spain: World Petroleum Congress, 7th, Mexico City, 1967, Proceedings, v. 2, p. 251-258.

Stoeckinger, W. T., 1976a, Valencian Gulf offer deadline nears, Part 1: $0 i l$ and Gas Journal, v. 74, no. 13, p. 197-204.

1976b, Valencian Gulf offer deadline nears, Part 2: 0 il and Gas Journal, v. 74, no. 14, p. 181-183.

United Kingdom

Kent, P. E., 1975, The tectonic development of Great Britain and the surrounding seas, in Woodland, A. W., ed., Petroleum and the continental shelf of northwest Europe, Volume 1: New York, John Wiley and Sons, p. 3-28.

Whitbread, D. R., 1975, Geology and petroleum possibilities west of the United Kingdom, in Woodland, A. W., ed., Petroleum and the continental shelf of northwest Europe, Volume 1: New York, John Wiley and Sons, p. 45-59. 
North America

\section{Alaska}

Churkin, M., Jr., 1970, Fold belts of Alaska and Siberia and drift between North America and Asia, in Geological Seminar on the North Slope of Alaska, California, 1970, Proceedings: Los Angeles, American Association of Petroleum Geologists, Pacific Section, p. G1-G17.

1973, Geologic concepts of Arctic Ocean Basin, in Pitcher, M. G., ed., Arctic geology: American Association of Petroleum Geologists Memoir 19, p. 485-499.

Collins, R. J., 1974, Petroleum resources and economics of Alaskan Arctic: Colorado School of Mines M.S. thesis.

Grantz, A., Holmes, M. L., and Kososki, B. A., 1975, Geologic framework of the Alaskan continental terrace in the Chukchi and Beaufort Seas, in Yorath, C. J., Parker, E. R., and Glass, D. J., eds., Canada's continental margins and offshore petroleum exploration: Canadian Society of Petroleum Geologists Memoir 4, p. 669-699.

Miller, D. J., Payne, T. G., and Gryc, G., 1959, Geology of Possible Petroleum Provinces in Alaska: U.S. Geological Survey Bulletin $1094,131 \mathrm{p}$.

\section{Atlantic Ocean}

Ewing, E., and others, 1973, Sediment distribution in the oceans--The Atlantic: Geological Society of America Bulletin, v. 84, no. 1, p. 71-88.

Kraft, J. C., Sheridan, R. E., and Maisano, M., 1971, Time-stratigraphic units and petroleum entrapment models in Baltimore Canyon Basin of Atlantic continental margin geosyncline: American Association of Petroleum Geologists Bulletin, v. 55, no.5, p. 658-679.

Mattick, R. E., Foote, R. Q., Weaver, N. L., and Grim, M. S., 1974, A preliminary report on USGS geophysical studies on the northeastern US outer continental shelf: Paper presented to annual meeting of Northeastern Section of Geological Society of America, Baltimore (March 1974).

Meyerhoff, A. A., 1973, Origin of Arctic and North Atlantic Oceans, in Pitcher, M. G., ed., Arctic geology: American Association of Petroleum Geologists Memoir 19, p. 562-582.

Noe-Nygaard, A., 1974, Cenozoic to recent volcanism in and around the North Atlantic Basin, in Nairn, A. E. M., and Stehli, F. G., eds., The ocean basins and margins, Volume 2, The North Atlantic: London, Plenum Press, p. 391-443. 
Roberts, D. G., and Caston, V. N. D., 1975, Petroleum potential of the deep Atlantic Ocean: World Petroleum Congress, 9th, Tokyo, 1975, Proceedings, v. 2, p. 281-298.

Sheridan, R. E., 1974, Atlantic continental margin of North America, in Burk, C. A., and Drake, C. L., eds., The geology of continental margins: New York, Springer-Verlag, p. 391-407.

Sheridan, R. E., and Osburn, W. L., 1975, Marine geological and geophysical studies of the Florida-Blake Plateau-Bahamas area, in Yorath, C. J., Parker, E. R., and Glass, D. J., eds., Canada's continental margins and offshore petroleum exploration: Canadian Society of Petroleum Geologists Memoir 4, p. 9-31.

Soper, N. J., and others, 1976, Late Cretaceous-early Tertiary stratigraphy of the Kangerdlugssuaq area, east Greenland, and the age of opening of the northeast Atlantic: Quarterly Journal of the Geological Society of London, v. 132, pt 1, p. 85-104.

$\underline{\text { Bering Sea }}$

Marlow, M. S., and others, 1975, Structure and evolution of the Bering Sea Shelf, in Yorath, C. J., Parker, E. R., and Glass, D. J., eds., Canada's continental margins and offshore petroleum exploration: Canadian Society of Petroleum Geologists Memoir 4, p. 893.

\section{California}

Hoskins, E. G., and Griffiths, J. R., 1971, Hydrocarbon potential of northern and central California offshore, in Cram, I. H., ed., Future petroleum provinces of the United States--their geology and potential: American Association of Petroleum Geologists Memoir 15, v. 1 , p. $212-228$.

Smith, M. B., 1964, Map showing distribution and configuration of basement rocks in California: U.S. Geological Survey Oil and Gas Investigations Map OM-125, scale 1:5,000,000.

Vedder, J. G., and others, 1974, Preliminary report on the geology of the continental borderland of southern California: U.S. Geological Survey Miscellaneous Field Studies Map MF-624.

Canada

Amoco Canadian Petroleum Company Limited and Imperial Oil Limited, offshore exploration staffs, 1974, Regional geology of the Grand Banks: American Association of Petroleum Geologists Bulletin, v. 58, no. 6 , pt. 2 , p. 1109-1123.

Bryant, R. G., Hill, J. V., and Roliff, W. A., 1975, Development in eastern Canada in 1974: American Association of Petroleum Geologists Bulletin, v. 59, no. 8, p. 1331-1343. 
Canada, Geological Survey of, 1970, Geology and economic minerals of Canada, Economic Geology report no. 1: Geological Survey of Canada, $838 \mathrm{p}$.

Jansa, L. F., and Wade, J., 1975, Paleogeography and sedimentation in the Mesozoic and Cenozoic southeastern Canada, in Yorath, C. J., Parker, E. R., and Glass, D. J., eds., Canada's continental margins and offshore petroleum exploration: Canadian Society of Petroleum Geologists Memoir 4, p. 79-102.

King, L. H., and MacLean, B., 1976, Geology of the Scotian Shelf and adjacent areas in King, L. H., and MacLean, B., eds., Geology of the Scotian Shelf: Ottawa, Canadian Hydrographic Service -Department of the Environment and the Geological Survey of Canada -Department of Energy, Mines and Resources, Marine Sciences Paper 7, Geological Survey of Canada Paper 74-31, p. 1-31.

King, R. E., 1975, Canadian Arctic promises future gas and oil supply: World 0il, v. 181, no. 7, p. 53-59.

Laroche, P. J., 1975, The geological setting of the Gulf of St. Lawrence, in Yorath, C. J., Parker, E. R., and Glass, D. J., eds., Canada's continental margins and offshore petroleum exploration: Canadian Society of Petroleum Geologists Memoir 4, p. 892.

McCrossan, R. G., ed., 1973, The future petroleum provinces of Canada-their geology and potential: Canadian Society of Petroleum Geologists Memoir 1, $720 \mathrm{p}$.

McCrossan, R. G., and Glaister, R. P., eds., 1964, Geological history of western Canada (Atlas): Calgary, Alberta Society of Petroleum Geologists.

Meyerhoff, A. A., 1973, Origin of Arctic and north Atlantic Oceans, in Pitcher, M. G., ed., Arctic geology: American Association of Petroleum Geologists Memoir 19, p. 562-582.

Meyerhoff, H. A., and Meyerhoff, A. A., 1973, Arctic geopolitics, in Pitcher, M. G., ed., Arctic geology: American Association of Petroleum Geologists Memoir 19, p. 646-670.

Murray, J. W., and Tiffin, D. L., 1974, Patterns of deformation, sedimentation and tectonism southwestern Canadian continental margin: Société Gélogique de Belgique, Annales, v. 97, no. 1, p. 169-183.

Sheridan, R. E., and Drake, C. L., 1968, Seaward extension of the Canadian Appalachians: Canadian Journal of Earth Sciences, v. 5, no. 3, p. 337-373.

Sherwin, D. F., 1975, Canada's east coast petroleum potential only been scratched: 0il and Gas Journal, v. 73, no. 17, p. 100-104. 
Sokolov, B. A., 1976, Geologic structure and petroleum potential of the arctic segment, in Sokolov, B. A. and others, Petroleum resources of seas and oceans: Moscow, Mir Publishers, Chapter 10, p. 215-239.

Stacey, R. A., 1975, Structure of the Queen Charlotte Basin, in Yorath, C. J., Parker, E. R., and Glass, D. J., eds., Canada's continental margins and offshore petroleum exploration: Canadian Society of Petroleum Geologists Memoir 4, p. 723-741.

Uchupi, E., Ballard, R. D., and Ellis, J. P., 1977, Continental slope and upper rise off western Nova Scotia and Georges Bank: American Association of Petroleum Geologists Bulletin, v. 61, no. 9, p. 1483-1492.

Yorath, C. J., Parker, E. R., and Glass, D. J., eds., 1975, Canada's continental margins and offshore petroleum exploration: Canadian Society of Petroleum Geologists Memoir 4, 898 p.

\section{Gulf of Mexico}

Martin, R. G., Jr., 1975, Isopach of sediments on Paleozoic and oceanic basement--Gulf Coast, U.S.A.: Unpublished work map, scale $1: 5,000,000$.

Moore, G. W., and Castillo, L. D., 1974, Tectonic evolution of the southern Gulf of Mexico: Geological Society of America Bulletin, v. 85 , no. 4 , p. 607-618.

$\underline{\text { Mexico }}$

Acosta-Estevez, R., 1973, Petroleum development in Mexico in 1972: American Association of Petroleum Geologists Bulletin, v. 57, no. 10, p. 2126-2135.

Alvarez, M., Jr., 1949, Tectonics of Mexico: American Association of Petroleum Geologists Bulletin, v. 33, no. 8, p. 1319-1335.

Beal, C. H., 1948, Reconnaissance of the geology and oil possibilities of Baja California, Mexico: Geological Society of America Memoir 31, $171 \mathrm{p}$.

Beebe, B. W., 1968, Occurrence of natural gas in Mexico, in Beebe, B. W., and Curtis, B. F., eds., Natural gases of North America: American Association of Petroleum Geologists Memoir 9, v. 1, p. 209-229.

Cserna, Z. de, 1961, Tectonic map of Mexico: Geological Society of America, scale 1:2,500,000. 
Doyle, L. J., and Gorsline, D. S., 1977, Marine geology of Baja California continental borderland, Mexico: American Assciation of Petroleum Geologists Bulletin, v. 61, no. 6, p. 903-917.

Gardner, J., 1945, Mollusca of the Tertiary formations of northeastern Mexico: Geological Society of America Memoir 11, 332 p.

Guzman, E. J., and Cserna, Z. de, 1963, Tectonic history of Mexico, in Childs, 0. E., and Beebe, B. W., eds., Backbone of the Americas: American Association of Petroleum Geologists Memoir 2, p. 113-129.

Helu, P. C., Verdugo, V. R., and Barcenas P. R., 1977, Origin and distribution of tertiary conglomerates, Veracruz Basin, Mexico: American Association of Petroleum Geologists Bulletin, v. 61, no. 2, p. 207-226.

Imlay, R. W., 1944, Cretaceous formations of Central America and Mexico: American Association of Petroleum Geologists Bulletin, v. 28, no. 8, p. 1077-1195.

McCaslin, J. C., 1974, Mexican find emphasizes need for deeper look: $0 i 1$ and Gas Journal, v. 72, no. 46, p. 97.

Richards, H. G., 1963, Stratigraphy of earliest Mesozoic sediments in southeastern Mexico and western Guatemala: American Association of Petroleum Geologists Bulletin, v. 47, no. 10, p. 1861-1870.

Uhink, F. M., 1965, Petroleum development in Mexico: American Association of Petroleum Geologists Bulletin, v. 49, no. 8, p. 1102-1111.

Newfoundland

Jansa, L. F., and Wade, J., 1975, Geology of the continental margin off Nova Scotia and Newfoundland, in Van Der Linden, W. J. M., and Wade, J. A., eds., Offshore geology of eastern Canada: Geological Survey of Canada Paper 74-30, v. 2, p. 51-106.

\section{United States}

Cram, I. H., ed., 1971, Future petroleum provinces of the United States-their geology and potential: American Association of Petroleum Geologists Memoir 15, 2 volumes, 1496 p.

McDowe11, A. N., 1975, What are the problems in estimating the oil potential of a basin?: $0 i 1$ and Gas Journal, v. 73, no. 23, p. 8590.

Miller, B. M., and others, 1975, Geological estimates of undiscovered recoverable oil and gas resources in the United States: U.S. Geological Survey Circular 725, 78 p. 


\section{South America}

\section{South America--general}

Childs, O. E., and Beebe, B. W., eds., 1963, Backbone of the Americas: American Association of Petroleum Geologists Memoir 2, 320 p.

Fairbridge, R. W., ed., 1975, The encyclopedia of world regional geology, Part 1, Western Hemisphere; Encyclopedia of earth sciences, Volume 8: Stroudsburg, Penn., Halsted Press, 703 p.

Forgotson, J. M., and Corgan, J. X., eds., 1963, Symposium on the petroleum geology of South America: Tulsa Geological Society Digest, v. 31 , $271 \mathrm{p}$.

Franchetean, J., and LePichon, X., 1972, Marginal fracture zones as structural framework of margins in south Atlantic Ocean: American Association of Petroleum Geologists Bulletin, v. 56, no. 6, p. 9911007 .

Galavis, J. A., and Louder, L. W., 1970, Preliminary studies on geomorphology, geology and geophysics on the continental shelf and slope of northern South America: World Petroleum Congress, 8th, Moscow, 1970, Proceedings, v. 2, p. 107-120.

Harrington, H. J., 1962, Paleogeographic development of South America: American Association of Petroleum Geologists Bulletin, v. 46, no. 10, p. 1773-1814.

Hayes, D. E., 1974, Continental margin of western South America, in Burk, C. A., and Drake, C. L., eds., The geology of continental margins: New York, Springer-Verlag, p. 581-590.

Jenks, W. F., ed., 1956, Handbook of South American Geology: Geological Society of America Memoir 65, 378 p.

Landes, K. K., 1959, Petroleum Geology (2nd ed.): New York, John Wiley and Sons, Inc., $443 \mathrm{p}$.

Moody, G. B., ed., 1961, Petroleum Exploration Handbook: New York, McGraw-Hill, 25 chapters.

Nygren, W. E., 1950, Bolivar geosyncline of northwestern South America: American Association of Petroleum Geologists Bulletin, v. 34, no. 10, p. 1998-2006.

Renz, H. H., 1942, Stratigraphy of northern South America, Trinidad, and Barbados: American Scientific Congress, 8th, Washington D. C., 1940, Proceedings, v. 4, p. 513-571.

Trumbull, J., and others, 1958, An introduction to the geology and mineral resources of the continental shelves of the Americas: U.S. Geological Survey Bulletin 1067, 92 p. 


\section{Argentina}

Criado, R. P., and others, 1959, The sedimentary basins of Argentina: World Petroleum Congress, 5th, New York, 1959, Proceedings, sec. 1, p. 883-899.

Dalziel, I. W. D., and others, 1974, South extremity of Andes--Geology of Isla de los Estados, Argentina Tierra del Fuego: American Association of Petroleum Geologists Bulletin, v. 58, no. 12, p. 2502-2512.

Dalziel, I. W. D., and Elliot, D. H., 1973, The Scotia Arc and Antarctic margin, in Nairn, A. E. M., and Stehli, F. G., eds., The ocean basins and margins, Volume 1, The South Atlantic: New York, Plenum Press, p. 171-246.

Ewing, M., Ludwig, W. J., and Ewing, J. I., 1963, Geophysical investigations in the submerged Argentina coastal plain, Part 1, Buenos Aires to peninsula Valdez: Geological Society of America Bulletin, v. 74, no. 3, p. 275-291.

Harrington, H. J., 1956, Argentina, in Jenks, W. F., ed., Handbook of South American geology: Geological Society of America Memoir 65, p. 131-165.

Irizany, 0. B., 1960, Que ofrece la Tierra del Fuego: Petroleo Interam, v. 18 , no. 5 , p. $36-42$.

Ludwig, W. J., Ewing, J. I., and Ewing, M., 1968, Structure of Argentine continental margin: American Association of Petroleum Geologists Bulletin, v. 52, no. 12, p. 2337-2368.

Padula, E., and Mingramm, A., 1963, The fundamental geological pattern of the Chaco-Parana Basin (Argentina) in relation to its oil possibilities: World Petroleum Congress, 6th, Frankfurt-am-Main, 1963, Proceedings, sec. 1, p. 293-310.

Salso, J. H., 1966, La Cuenca de Macachin, Provincia de la Pampa, Nota Preliminar: Revista Asociacion Geologica Argentina, v. 21, no. 2, p. 107-117.

Urien, C. M., and Ewing, M., 1974, Recent sediments and environments of southern Brazil, Uruguay, Buenos Aires, and Rio Negro continental shelf, in Burk, C. A., and Drake, C. L., eds., The Geology of Continental Margins: New York,Springer-Verlag, p. 157-177.

Urien, C. M., and Zambrano, J. J., 1973, The geology of the basins of the Argentine continental margin and Malvinas Plateau, in Nairn, A. E. M., and Stehli, F. G., eds., The ocean basins and margins, Volume 1, The South Atlantic: New York, Plenum Press, p. 135-166. 
Zambrano, J. J., and Urien, C. M., 1970, Geological outline of the basins in southern Argentina and their continuation off the Atlantic shore: Journal of Geophysical Research, v. 75, no. 8, p. 13631396.

Bolivia

Franco, A., 1974, Bolivia offers extraordinary possibilites for exploration: Petróleo Internacional, v. 32, no. 9, p. 46-53.

Helvig, J., 1972, Stratigraphy, sedimentation, paleogeography, and paleoclimates of Carboniferous ("Gondwana") and Permian of Bolivia: American Association of Petroleum Geologists Bulletin, v. 56, no. 6, p. 1008-1033.

Lamb, W. C., and Truitt, P., 1963, The petroleum geology of the Santa Cruz area, Bolivia: World Petroleum Congress, 6th, Frankfurt-amMain, 1963, Proceedings, sec. 1, p. 573-594.

Newe11, N. D., 1949, Geology of the Lake Titicaca region, Peru and Bolivia: Geological Society of America Memoir 36, 111 p.

Sonnenberg, F. P., 1963, Bolivia and the Andes, in Childs, 0. E., and Beebe, B. W., eds., Backbone of the Americas: American Association of Petroleum Geologists Memoir 2, p. 36-46.

Brazi1

Asmus, H. E., and Ponte, F. C., 1973, The Brazilian marginal basins, in Nairn, A. E. M., and Stehli, F. G., eds., The ocean basins and margins, Volume 1, The South Atlantic: New York, Plenum Press, p. 87-132.

Bauer, E. J., 1967, Genesis of lower Cretaceous "A" sandstone, Reconcavo Basin, Brazil: American Association of Petroleum Geologists Bulletin, v. 51 , no. 1 , p. 28-54.

Bigarella, J. J., 1973, Geology of the Amazon and Parnaiba Basins, in Nairn, A. E. M., and Stehli, F. G., eds., The ocean basins and margins, Volume 1, The South Atlantic: New York, Plenum Press, p. 25-79.

Brazil, 1971, Mapa geologico do Brasil: Ministerio das Minas e Energia, scale $1: 5,000,000,1$ sheet.

Butler, L. W., 1970, Shallow structure of the continental margin, southern Brazil and Uruguay: Geological Society of America Bulletin, v. 81, no. 4, p. 1079-1096.

Campos, C. W. M., Ponte, F. C., and Miura, K., 1974, Geology of the Brazilian continental margin, in Burk, C. A., and Drake, C. L., eds., The Geology of Continental Margins: New York, SpringerVerlag, p. 447-461. 
Delaney P. J. V., 1963, Quaternary geologic history of the coastal plain of Rio Grande do Sul, Brazil: Coastal Studies Institute, Technical Report no. 6, Louisiana State University, 63 p.

Delaney, P. J. V., 1966, Geology and geomorphology of the coastal plain of Rio Grande do Sul, Brazil, and northern Uruguay: Coastal Studies Institute, Louisiana State University Technical Report no. 15, 58 p.

Ealey, P. J., 1969, Marine geology of north Brazil--a reconnaissance survey: Urbana, University of Illinois, $\mathrm{Ph}$. D. thesis, $65 \mathrm{p}$.

Ghignone, J. I., and De Andrade, G., 1970, General geology and major oil fields of Reconcavo Basin, Brazil, in Halbouty, M. T., ed., Symposium of giant oil and gas fields of the world: American Association of Petroleum Geologists Memoir 14, p.337-358.

Kowsmann, R., Leyden, R., and Francisconi, 0., 1977, Marine seismic investigations, southern Brazil margin: American Association of Petroleum Geologists Bulletin, v. 61, no. 4, p. 546-557.

Kumar, N., 1978, Sediment distribution in western Atlantic off northern Brazil--structural controls and evolution: American Association of Petroleum Geologists Bulletin, v. 62, no. 2, p. 273-294.

Leyden, R., Ludwig, W. J., and Ewing, M., 1971, Structure of continental margin off Punta del Este, Uruguay, and Rio de Janeiro, Brazil: American Association of Petroleum Geologists Bulletin, v. 55, no. 12 , p. 2161-2173.

Link, W.K., 1959, The sedimentary framework of Brazil: World Petroleum Congress, 5th, New York, 1959, Proceedings, section 1, p. 901-923.

Meister, E. M., and Aurich, N., 1972, Geologic outline and oil fields of Sergipe Basin, Brazil: American Association of Petroleum Geologists Bulletin, v. 56, no. 6, p. 1034-1047.

Mesner, J. C., and Wooldridge, L. C. P., 1964, Maranhro Paleozoic Basin and Cretaceous coastal basins, north Brazil: American Association of Petroleum Geologists Bulletin, v. 48, no. 9, p. 1475-1512.

Morales, L. G., 1959, General geology and oil possibilities of the Amazonas Basin, Brazil: World Petroleum Congress, 5th, New York, 1959, Proceedings, sec. 1, p. 925-942.

Oliveira, A. I. de, 1956, Brazil, in Jenks, W. F., ed., Handbook of South American geology: Geological Society of America Memoir 65, p. 1-62.

Ponte, F. C., Fonseca, J. D. R., and Morales, R. G., 1977, Petroleum geology of eastern Brazilian continental margin: American Association of Petroleum Geologists Bulletin, v. 61, no. 9, p. 1470-1482. 
Sanford, R. M., and Lange, F. W., 1960, Basin-study approach to oil evaluation of Parana miogoesyncline, south Brazil: American Association of Petroleum Geologists Bulletin, v. 44, no. 8, p. 1316-1370.

Urien, C. M., and Ewing, M., 1974, Recent sediments and environments of southern Brazil, Uruguay, Buenos Aires, and Rio Negro continental shelf, in Burk, C. A., and Drake, C. L., eds., The geology of continental margins: New York, Springer-Verlag, p. 157-177.

Chile

Carlos, M. K., 1974, Geology of a part of the Pacific margin of Chile, in Burk, C. A., and Drake, C. L., eds., The geology of continental margins: New York, Springer-Verlag, p. 591-598.

Cecioni, G. O., and Garcia, A. F., 1960, Stratigraphy of coastal range in Tarapaca Province, Chile: American Association of Petroleum Geologists Bulletin, v. 44, no. 10, p. 1609-1620.

Chile, 1968, Mapa geologico de Chile: Instituto de Investigaciones Geologicos, scale $1: 1,000,000,7$ sheets.

Katz, H. R., 1971, Continental margin in Chile--its tectonic style compressional or extensional: American Association of Petroleum Geologists Bulletin, v. 55, no. 10, p. 1753-1758.

Lomnitz, C., 1962, Gravity measurements in the central valley of Chile: World Petroleum Congress, 5th, New York, 1962, Proceedings, sec. I, p. 801-814.

Williams, R. N., 1963, Cordillera of Chile, in Childs, 0. E., and Beebe, B. W., eds., Backbone of the Americas: American Association of Petroleum Geologists Memoir 2, p. 29-35.

Colombia

Campbe11, C. J., and Burgl, H., 1965, Section through the eastern Cordillera of Colombia, South America: Geological Society of America Bulletin, v. 76, no. 5, p. 567-590.

Case, J. E., and others, 1971, Tectonic investigations in western Colombia and eastern Panama: Geological Society of America Bulletin, v. 82, no. 10 , p. 2685-2711.

Case, J. E., and MacDonald, W. R., 1973, Regional gravity anomalies and crustal structure in northern Colombia: Geological Society of America Bulletin, v. 84, no. 9, p. 2905-2916.

Freeman, R. N., 1972, Petroleum geology of Subandean Basin of Ecuador, northern Peru, and southern Colombia: American Association of Petroleum Geologists Bulletin, v. 56, no. 3, p. 617-618. 
Hatfield W. C., 1958, Colombia's geological features: Petroleum Engineer, v. 30 , no. 2 , p. 21-29.

Hubach, H., and others, compilers, 1962, Mapa geologico de Colombia: Ministerio de Minas y Petroleos, scàle 1:500,000, 1 sheet.

Jacobs, C., Burg1, H., and Conley, D. I., 1963, Backbone of Colombia, in Childs, 0. E., and Beebe, B. W., eds., Backbone of the Americas: American Association of Petroleum Geologists Memoir 2, p. 62-72.

Miller, J. B., 1962, Tectonic trends in Sierra de Perija and adjacent parts of Venezuela and Colombia: American Association of Petroleum Geologists Bulletin, v. 46, no. 9, p. 1565-1595.

Notestein, F. B., Hubman, C. W., and Bowler, J. W., 1944, Geology of the Barco concession, Republic of Colombia, South America: Geological Society of America Bulletin, v. 55, no. 10, p. 1165-1216.

Shepard, F. P., 1973, Sea floor off Magdalena Delta and Santa Marta area, Colombia: Geological Society of America Bulletin, v. 84, no. 6, p. 1955-1972.

Trumpy, D., 1943, Pre-Cretaceous of Colombia: Geological Society of America Bulletin, v. 54, no. 9, p. 1281-1304.

\section{Ecuador}

Ballen, J. G., 1969, Mapa geologico de la Republica del Ecuador: Servicio Nacional de Geologia y Mineria, scale 1:1,000,000, 2 sheets.

Davalos, J. C., 1973, A new economy for Ecuador, in Petrick, A., Jr., ed., Texaco and Gulf strike oil: Colorado school of Mines Quarterly, v. 68 , no. 4, p. $73-79$.

Feininger, T., 1975, Origin of petroleum in the Oriente of Ecuador: American Association of Petroleum Geologists Bulletin, v. 59, no. 7, p. 1166-1175.

Freeman, R. N., 1972, Petroleum geology of Subandean Basin of Ecuador, northern Peru, and southern Colombia: American Association of Petroleum Geologists Bulletin, v. 56, no. 3, p. 617-618.

Jarrin, A., 1974, Exploration and development of new hydrocarbon resources in Pacific basins of Ecuador: American Association of Petroleum Geologists Bulletin, v. 58, no. 7, p. 1442.

Schwade, I. T., 1962, Petroleum geology of coastal Peru and Ecuador: American Association of Petroleum Geologists Bulletin, v. 46, no. 2 , p. 279 . 
Sma11, J., Jr., 1963, Stratigraphy of southwest Ecuador and Ancon oil field studies: Dissertation Abstracts, v. 24, no. 3, p. 1139-1140.

Tschopp, H. J., 1953, Oil explorations in the Oriente of Ecuador: American Association of Petroleum Geologists Bulletin, v. 37, no. 10, p. 2303-2347.

\section{$\underline{\text { Paraguay }}$}

Ecke1, E. B., 1959, Geology and mineral resources of Paraguay--a reconnaissance: U.S. Geological Survey Professional Paper 327, 110 p.

\section{$\underline{\text { Peru }}$}

Freeman, R. N., 1972, Petroleum geology of Subandean Basin of Ecuador, northern Peru and southern Colombia: American Association of Petroleum Geologists Bulletin, v. 56, no. 3, p. 617-618.

Koch, E., 1959, Geology of the Maquia oil field in eastern Peru and its regional setting: World Petroleum Congress, 5th, New York, 1959, Proceedings, sec. 1, p. 591-601.

Kumme1, B., 1948, Geological reconnaissance of the Contamana region, Peru: Geological Society of America Bulletin, v. 59, no. 12, pt. 1, p. 1217-1265.

Newell, N. D., 1949, Geology of the Lake Titicaca region, Peru and Bolivia: Geological Society of America Memoir 36, 111 p.

Ruegg, W., 1964, The productive and promising oil basins of Peru: Vereinigung Schweizerischer Petroleum-Geologen und Ingenieure, $v$. 30 , no. 79, p. 8-25.

Schwade, I. T., 1962, Petroleum geology of coastal Peru and Ecuador: American Association of Petroleum Geologists Bulletin, v. 46, no. 2 , p. 279.

Wilson, J. J., 1963, Cretaceous stratigraphy of central Andes of Peru: American Association of Petroleum Geologists Bulletin, v. 47, no. 1 , p. 1-34.

\section{Uruguay}

Butler, L. W., 1970, Shallow structure of the continental margin, southern Brazil and Uruguay: Geological Society of America Bulletin, v. 81, no. 4, p. 1079-1096.

Delaney, P. J. V., 1966, Geology and geomorphology of the coastal plain of Rio Grande do Sul, Brazil, and northern Uruguay: Coastal Studies Institute, Louisiana State University, Technical Report no. 15, 58 $\mathrm{p}$. 
Leyden, R., Ludwig, W. J., and Ewing, M., 1971, Structure of continental margin off Punta del Este, Uruguay, and Rio de Janeiro, Brazil: American Association of Petroleum Geologists Bulletin, v. 55, no. 12, p. 2161-2173.

Urien, C. M., and Ewing, M., 1974, Recent sediments and environments of southern Brazil, Uruguay, Buenos Aires, and Rio Negro continental shelf, in Burk, C. A., and Drake, C. L., eds., The Geology of Continental Margins: New York, Springer-Verlag, p. 157-177.

\section{Venezuela}

Bertagne, R. G., 1963, Some aspects of the tectonics of the Maracaibo block, Venezuela: Asociacion Venezolana de Geologla, Minerla y Petróleo Boletín Informativo, v. 6, no. 8, p. 233-260.

Borger, H. D., and Lenert, E. F., 1959, The geology and development of the Bolivian coastal field at Maracaibo, Venezuela: World Petroleum Congress, 5th, New York, 1959, Proceedings, sec. 1, p. 481-498.

Brown, H. D., Cunningham, J. D., and Salisch, H. A., 1970, South Lake Maracaibo log analysis: Asociación Venezolana de Geologia, Minerla y Petroleo Boletin Informativo, v. 13, no. 11, p. 343-356.

Bucher, W. H., compiler, 1950, Geologic-tectonic map of the United States of Venezuela (except the Territory of Amazonas and part of the State of Bolivar): Geological Society of America, scale $1: 1,000,000,1$ sheet.

1952, Geologic structures and orogenic history of Venezuela: Geological Society of America Memoir 49, $113 \mathrm{p}$.

Coffinières, B., and others, 1971, Synthèse paléogéographique et pétrolière du Venezuela occidental ( 2 parties): Revue de 1 'Institut Français du Pétrole, v. 26, no. 1, p. 50-72.

Coronel, G. R., 1967, A geological outline of the Gulf of Venezuela: World Petroleum Congress, 7 th, Mexico City, 1967, Proceedings, v. 2, p. 799-812.

Dengo, G., 1953, Geology of the Caracas region, Venezuela: Geological Society of America Bulletin, v. 64, no. 1, p. 7-40.

Dufour, J., 1955, Some oil-geological characteristics of Venezuela: World Petroleum Congress, 4th, Rome, 1955, Proceedings, sec. 1, p. 19-36.

Galavis, J. A., and Velande, C. H. M., 1967, Geological study and preliminary evaluation of potential reserves of heavy oil of the Orinoco Tar Belt, eastern Venezuelan Basin: World Petroleum Congress, 7 th, Mexico City, 1967, Proceedings, v. 2, p. 229-234. 
Hedberg, H. D., 1950, Geology of the eastern Venezuela Basin (AnzoateguiMonagas-Sucre-eastern Guarico portion): Geological Society of America Bulletin, v. 61, no. 11, p. 1173-1216.

Hotz, E. E., 1963, Petroleum occurrence in the Cretaceous of Venezuela: World Petroleum Congress, 6th, Frankfurt-am-Main, 1963, Proceedings, sec. 1, p. 115-140.

Institut Français du Pétrole, 1974, Principales zones pétrolières du Venezuela: Institut Français due Pétrole, Texte and Annexe, 1, 2 and 3.

Koldewijn, B. W., 1958, Sediments of the Paria-Trinidad Shelf, reports of the Orinoco Shelf expedition: The Hague, Mouton and Co., v. 3, $109 \mathrm{p}$.

Lattimore, R. K., Weeks, L. A., and Mordock, L. W., 1971, Marine geophysical reconnaissance of continental margin north of Paria Peninsula, Venezuela: American Association of Petroleum Geologists Bulletin, v. 55, no. 10, p. 1719-1729.

Martinez, A. R., 1966, Our gift, our oil: The Netherlands, M. V. Drukkerij, D. Reidel-Dordrecht, 199 p.

1972, Los recursos de hidrocarburos de Venezuela: Memoria Cuarto Congreso Geologico Venezolano, v. 5, no. 5, p. 2687-2727.

Mencher, E., and others, 1953, Geology of Venezuela and its oil fields: American Association of Petroleum Geologists Bulletin, v. 37, no. 4, p. 690-777.

Miller, J. B., 1962, Tectonic trends in Sierra de Perija and adjacent parts of Venezuela and Colombia: American Association of Petroleum Geologists Bulletin, v. 46, no. 9, p. 1565-1595.

Miller, J. B., and others, 1958, Habitat of oil in the Maracaibo Basin, Venezuela, in Weeks, I. G., ed., Habitat of oil, a symposium: American Association of Petroleum Geologists, p. 601-640.

Renz, H. H., and others, 1958, The eastern Venezuelan Basin, in Weeks, L. G., ed., Habitat of oil, a symposium: American Association of Petroleum Geologists, p. 551-600.

Rod, E., 1959, West end of Serrania del Interior, eastern Venezuela: American Association of Petroleum Geologists Bulletin, v. 43, no. 4 , p. 772-789. 
Salvador, A., and Hotz, E. E., 1963, Petroleum occurrence in the Cretaceous of Venezuela: World Petroleum Congress, 6th, Frankfurt-am-Main, 1963, Proceedings, sec. 1, p. 115-140.

Smith, R. J., 1953, Geology of the Los Teques-Cua region, Venezuela: Geological Society of America Bulletin, v. 64, no. 1, p. 41-64.

Stevenson, H. R., 1962, Geophysical case history of the Alturitas Concession, State of Zulia, western Venezuela: Asociación Venezolana de Geologia, Minerla y Petroleo Boletin Informativo, v. 5, no. 8, p. 231-249.

Van Andel, T. H., 1967, The Orinoco Delta: Journal of Sedimentary Petrology, v. 37, no. 2, p. 297-310.

Weeks, L. A., and others, 1971, Structural relations among Lesser Antilles, Venezuela and Trinidad-Tobago: American Association of Petroleum Geologists Bulletin, v. 55, no. 10, p. 1741-1752.

Wheeler, C. B., 1963, Oligocene and lower Miocene stratigraphy of western and northeastern Falcon Basin, Venezuela: American Association of Petroleum Geologists Bulletin, v. 47, no. 1, p. 35-68.

Zambrano, E., and others, 1970, Paleogeographic and petroleum synthesis, western Venezuela (1): Revue de I'Institut Français du Pétrole, v. 25, no. 12, p. 1449-1492. 